\title{
Y-12 Site Environmental Protection Program Implementation Plan (EPPIP)
}

\author{
Prepared by the \\ Environmental Management Department \\ Health, Safety, Environment, and \\ Accountability Organization
}

November 1996

Prepared by the

Oak Ridge Y-12 Plant

Post Office Box 2009, Oak Ridge, Tennessee 37831-8169

Managed by

LOCKHEED MARTIN ENERGY SYSTEMS, INC.

for the

U.S. DEPARTMENT OF ENERGY

Under Contract DE-AC05-84OR21400

ESTRIBUTON OF TIIS DOCUMENT IS UNLIMTED

MASTER 


\section{DISCLAIMER}

This report was prepared as an account of work sponsored by an agency of the United States Government. Neither the United States Government nor any agency thereof, nor any of their employees, makes any warranty, express or implied, or assumes any legal liability or responsibility for the accuracy, completeness, or usefulness of any information, apparatus, product, or process disclosed, or represents that its use would not infringe privately owned rights. Reference herein to any specific commercial product, process, or service by trade name, trademark, manufacturer, or otherwise does not necessarily constitute or imply its endorsement, recommendation, or favoring by the United States Government or any agency thereof. The views and opinions of authors expressed herein do not necessarily state or reflect those of the United States Government or any agency thereof. 


\section{DISCLAIMER}

Portions of this document may be illegible electronic image products. Images are produced from the best available original document. 


\section{Contents}

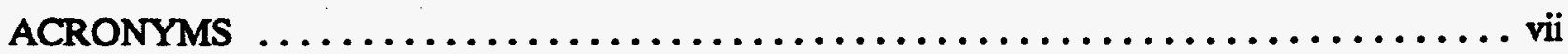

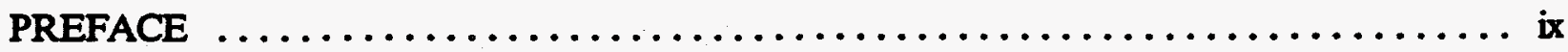

1. DESCRIPTION OF ENVIRONMENTAL PROTECTION PROGRAM . . . . . . . 1

1.1 GENERAL .................................. 1

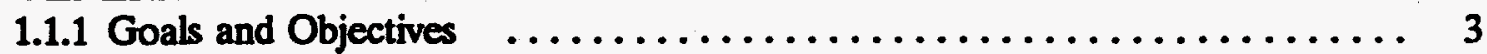

1.2 ORGANIZATION, ROLES, AND RESPONSIBILITIES $\ldots \ldots \ldots \ldots \ldots \ldots \ldots .8$

1.2.1 DOE Oak Ridge Operations Office .................... 11

1.2.2 DOE Contractor Organization and Responsibilities $\ldots \ldots \ldots \ldots \ldots \ldots \ldots \ldots$

1.2.2.1 Energy Systems . . . . . . . . . . . . . . . . . . . . 15

1.2.2. MK-Ferguson, Construction Manager ................ 33

1.2.2. Johnson Controls World Services, Incorporated . . . . . . . . . 33

2. REPORTING OF ENVIRONMENTAL RELEASES $\ldots \ldots \ldots \ldots \ldots \ldots \ldots \ldots \ldots \ldots$

21 NOTIFICATION FOR ENVIRONMENTAL OCCURRENCES $\ldots \ldots \ldots \ldots$.

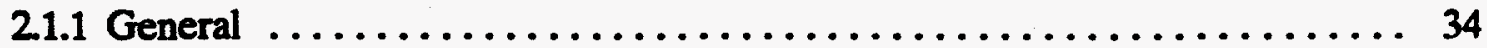

2.1.2 Guidance on Reporting of Enforcement Actions or Notices of Violation (NOVs) $\ldots \ldots \ldots \ldots \ldots \ldots \ldots \ldots \ldots \ldots \ldots \ldots$

2.1.3 Reporting Procedures and Documentation ................ 35

2.1.4 Use of Monitoring Data to Detect Environmental Events ... . . . . . . 35

2.1 .5 Responsibilities . . . . . . . . . . . . . . . . . . . . . . . 35

2.2 EFFLUENT INFORMATION SYSTEM AND ON-SITE DISCHARGE

INFORMATION SYSTEM (ODIS) REPORTS $\ldots \ldots \ldots \ldots \ldots \ldots \ldots \ldots \ldots \ldots$

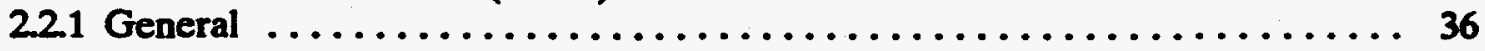

2.22 Procedure for Preparing Effluent Information System and ODIS Reports . . 37

2.2.3 Relationship of the Effluent Information System and ODIS Report to

Other Effluent Monitoring/Sampling and Reporting ............. 37

3. GENERAL PLANNING AND REPORTING $\ldots \ldots \ldots \ldots \ldots \ldots \ldots \ldots \ldots \ldots$

3.1 LONG-RANGE ENVIRONMENTAL PROTECTION PLAN $\ldots \ldots \ldots \ldots \ldots$

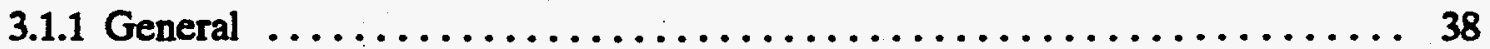

3.2 ANNUAL SITE ENVIRONMENTAL REPORT $\ldots \ldots \ldots \ldots \ldots \ldots \ldots \ldots$

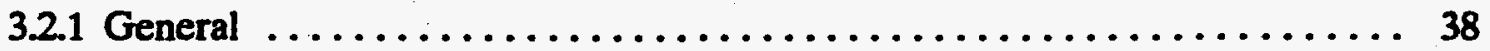

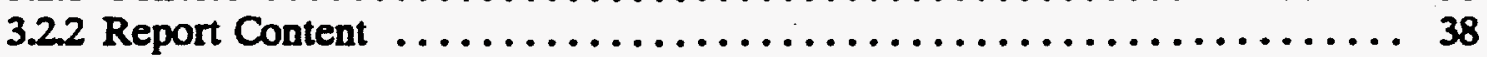

3.2.3 Data Management and Information Transfer $\ldots \ldots \ldots \ldots \ldots \ldots \ldots \ldots \ldots$

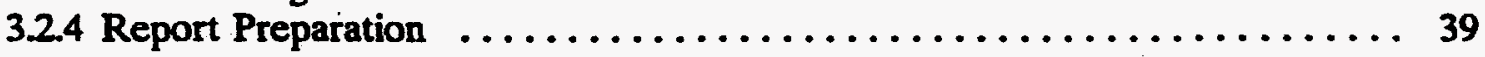

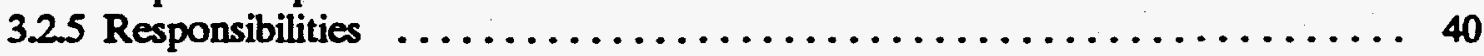

3.2 .6 Schedule $\ldots \ldots \ldots \ldots \ldots \ldots \ldots \ldots \ldots \ldots \ldots \ldots \ldots \ldots \ldots \ldots \ldots \ldots \ldots \ldots$

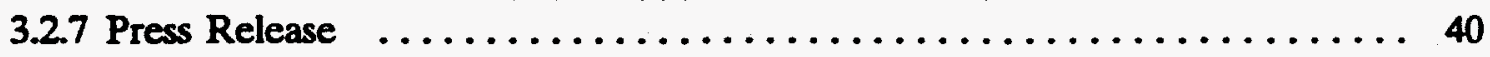

3.3 OMB CIRCULAR A-106 REPORT $\ldots \ldots \ldots \ldots \ldots \ldots \ldots \ldots \ldots \ldots \ldots \ldots$ 


\section{Contents (cont)}

3.4 ENVIRONMENTAL RESTORATION AND WASTE MANAGEMENT FIVE-YEAR PLAN $\ldots \ldots \ldots \ldots \ldots \ldots \ldots \ldots \ldots \ldots \ldots \ldots \ldots, 41$

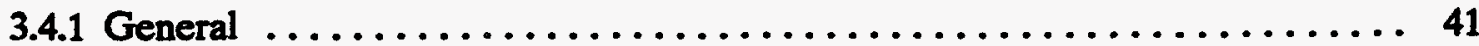

3.4.2 Plan Preparation $. \ldots \ldots \ldots \ldots \ldots \ldots \ldots \ldots \ldots \ldots \ldots \ldots \ldots \ldots, 42$

3.4.3 Responsibilities $\ldots \ldots \ldots \ldots \ldots \ldots \ldots \ldots \ldots \ldots \ldots \ldots \ldots \ldots \ldots, 42$

3.4.4 Site-Specific Plan .............................. 42

3.4.5 Activity Data Sheets ........................... 43

3.5 ENVIRONMENT, SAFETY, AND HEALTH FIVE-YEAR PLAN $\ldots \ldots \ldots \ldots 43$

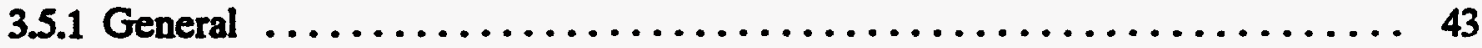

3.5.2 Plan Preparation $. . \ldots \ldots \ldots \ldots \ldots \ldots \ldots \ldots \ldots \ldots \ldots \ldots \ldots \ldots, 43$

3.5.3 Responsibilities ................................ 43

3.5.4 Schedule $. \ldots \ldots \ldots \ldots \ldots \ldots \ldots \ldots \ldots \ldots \ldots \ldots \ldots \ldots \ldots \ldots, 44$

4. SPECIAL PROGRAMS AND PLANS $\ldots \ldots \ldots \ldots \ldots \ldots \ldots \ldots \ldots \ldots \ldots$

4.1 GROUNDWATER PROTECTION MANAGEMENT PROGRAMS $\ldots \ldots \ldots \ldots 44$

4.1.1 General ................................... 44

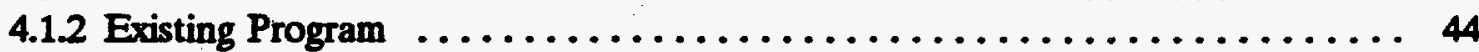

4.1.3 Groundwater Protection Program Management Plan.$\ldots \ldots \ldots \ldots \ldots \ldots .45$

4.1.4 Responsibilities ................................ 47

4.2 Y-12 PLANT POLLUTION PREVENTION PLAN $\ldots \ldots \ldots \ldots \ldots \ldots \ldots \ldots, 47$

4.21 Waste Minimization $\ldots \ldots \ldots \ldots \ldots \ldots \ldots \ldots \ldots \ldots \ldots \ldots \ldots, 47$

4.2 .2 Organization and Infrastructure $\ldots \ldots \ldots \ldots \ldots \ldots \ldots \ldots \ldots \ldots \ldots, 47$

4.23 Waste Generators and Employees ....................... 48

4.2.4 Pollution Prevention Program Strategy, Objectives, and Goals .......... 48

4.2.4.1 Strategy $\ldots \ldots \ldots \ldots \ldots \ldots \ldots \ldots \ldots \ldots \ldots \ldots \ldots \ldots \ldots, 48$

4.2 .4 .2 Objectives $\ldots \ldots \ldots \ldots \ldots \ldots \ldots \ldots \ldots \ldots \ldots \ldots \ldots \ldots \ldots, 48$

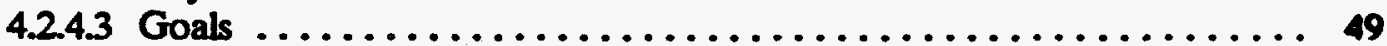

4.2.5 Pollution Prevention Opportunity Assessments $\ldots \ldots \ldots \ldots \ldots \ldots \ldots$ 49

4.2.6 Pollution Prevention Awareness $\ldots \ldots \ldots \ldots \ldots \ldots \ldots \ldots \ldots \ldots$ so

4.3 ENVIRONMENTAL ALARA PROGRAM ................... so

4.4 PREOPERATIONAL MONITORING OF FACILITIES, SITES,

AND OPERATIONS $\ldots \ldots \ldots \ldots \ldots \ldots \ldots \ldots \ldots \ldots \ldots \ldots \ldots \ldots, \ldots \ldots \ldots$ so

4.4.1 General $\ldots \ldots \ldots \ldots \ldots \ldots \ldots \ldots \ldots \ldots \ldots \ldots \ldots \ldots \ldots \ldots \ldots \ldots$ so

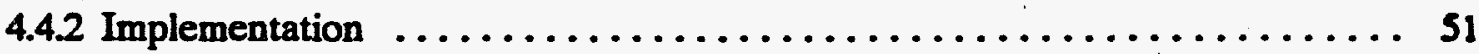

4.4.3 Responsibilities ............................. S1

4.5 ORR SITE TREATMENT PLAN (STP) TO COMPLY WITH THE

FEDERAL FACILITIES COMPLIANCE ACT $\ldots \ldots \ldots \ldots \ldots \ldots \ldots \ldots, \$ 2$

4.5.1 The Federal Facilities Compliance Act $\ldots \ldots \ldots \ldots \ldots \ldots \ldots \ldots \ldots, 52$

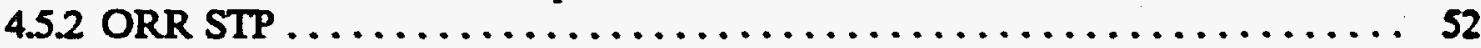

4.5.3 Milestones and Schedules $\ldots \ldots \ldots \ldots \ldots \ldots \ldots \ldots \ldots \ldots \ldots \ldots, 53$

4.5.4 Responsibilities ............................. 53 


\section{Contents (cont)}

5. ENVIRONMENTAL MONTTORING PROGRAMS $\ldots \ldots \ldots \ldots \ldots \ldots \ldots \ldots, 53$

5.1 ENVIRONMENTAL MONITORING PLAN $\ldots \ldots \ldots \ldots \ldots \ldots \ldots \ldots \ldots, 53$

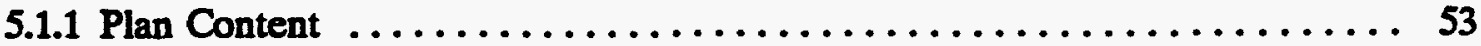

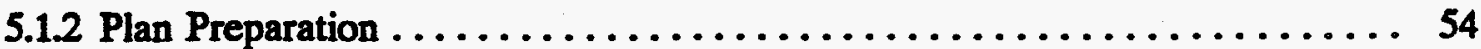

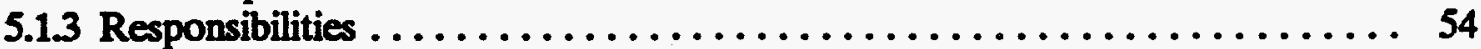

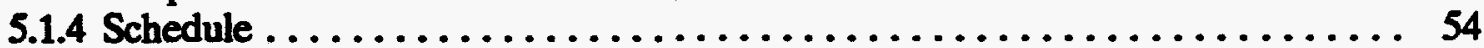

5.2 ENVIRONMENTAL MONITORING ACTIVITIES $\ldots \ldots \ldots \ldots \ldots \ldots \ldots, 54$

5.2 .1 Program Implementation $\ldots \ldots \ldots \ldots \ldots \ldots \ldots \ldots \ldots \ldots \ldots \ldots \ldots \ldots$

6. QUALITY ASSURANCE AND DATA VERIFICATION $\ldots \ldots \ldots \ldots \ldots \ldots \ldots$. 58

6.1 QUALITY ASSURANCE PROGRAM $\ldots \ldots \ldots \ldots \ldots \ldots \ldots \ldots \ldots \ldots \ldots, 58$

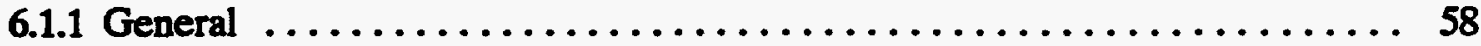

6.1.2 Organizational Responsibilities $\ldots \ldots \ldots \ldots \ldots \ldots \ldots \ldots \ldots \ldots \ldots, 58$

6.1.3 Field Monitoring Quality Assurance $\ldots \ldots \ldots \ldots \ldots \ldots \ldots \ldots \ldots \ldots, 59$

6.1 .4 Laboratory Analyses Quality Assurance $\ldots \ldots \ldots \ldots \ldots \ldots \ldots \ldots \ldots 62$

6.2 LABORATORY CERTIFICATION $\ldots \ldots \ldots \ldots \ldots \ldots \ldots \ldots \ldots \ldots \ldots \ldots \ldots \ldots$

6.2 .1 Environmental Laboratories Used by the Y-12 Plant $\ldots \ldots \ldots \ldots \ldots \ldots 63$

6.2 .2 Status of Certification $\ldots \ldots \ldots \ldots \ldots \ldots \ldots \ldots \ldots \ldots \ldots \ldots \ldots, 64$

6.23 Responsibilities ................................. 64

6.24 DOE Laboratory Quality Assurance Program ................. 64

6.3 INDEPENDENT DATA VERIFICATION PROGRAM $\ldots \ldots \ldots \ldots \ldots \ldots 64$

APPENDIXES

A Key Federal Statutes, Executive Orders, and DOE Orders $\ldots \ldots \ldots \ldots \ldots \ldots$ A-1

B Regulations Applicable or Potentially Applicable to the Y-12 Plant $\ldots \ldots \ldots \ldots$ B-1

C ORIG 5400.1C, General Environmental Protection Program ............... C-1

D Libraries and Public Reading Rooms DOE-Oak Ridge Operations Field Office ... . D-1

E Y-12 Summary of Report Contents for the Oak Ridge Reservation Annual Site Environmental Report ............................... E-1

F Y-12 Schedule for Preparation and Release of the Oak Ridge Reservation Environmental Report ............................... F-1

G Environmental Monitoring Plan for the Oak Ridge Reservation, Table of Contents 


\section{Figures}

Figure

Title

Page

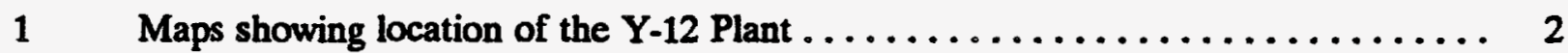

2 Pyramid for environmental excellence at the $Y-12$ Plant $\ldots \ldots \ldots \ldots \ldots$

3 Oak Ridge Implementation Guidance for major DOE orders

on environmental quality and waste management ................. 9

4 DOE/Energy Systems communication matrix $\ldots \ldots \ldots \ldots \ldots \ldots \ldots \ldots$

$5 \quad$ DOE Y-12 Site Office organizational chart $\ldots \ldots \ldots \ldots \ldots \ldots \ldots \ldots \ldots \ldots$

6 DOE-ORO Environmental Restoration and Waste Management Divisions

organizational chart $\ldots \ldots \ldots \ldots \ldots \ldots \ldots \ldots \ldots \ldots \ldots \ldots \ldots \ldots \ldots \ldots$

$7 \quad$ Key personnel and areas of responsibility for the Environmental Operations

Branch and the Environmental Remediation Branch in the DOE-ORO

Environmental Protection Division $\ldots \ldots \ldots \ldots \ldots \ldots \ldots \ldots \ldots \ldots \ldots$

$8 \quad$ Y-12 Plant Environmental Management organization chart $\ldots \ldots \ldots \ldots \ldots \ldots$

9 Compliance Planning and Resources Department organization chart ........ 22

10 Energy Systems Environmental Restoration and Waste Management

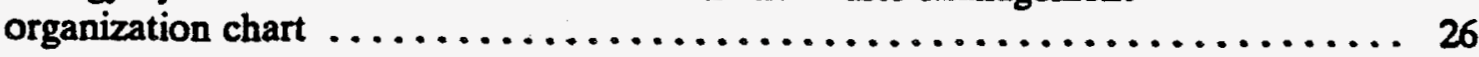

11 Energy Systems Environmental Restoration Division ................. 27

$12 \quad$ Y-12 Plant Waste Management Organization $\ldots \ldots \ldots \ldots \ldots \ldots \ldots \ldots$

$13 \quad$ Y-12 Plant organizational chart $\ldots \ldots \ldots \ldots \ldots \ldots \ldots \ldots \ldots \ldots \ldots \ldots \ldots$

\section{Table}

Relationships among the Environmental Monitoring Plan, Quality Program Plan, DOE Order 5700.6C, NQA-1, and QAMS-005/80 


\section{Acronyms}

\begin{tabular}{|c|c|}
\hline $\mathrm{ABC}$ & Aluminum Beverage Cans \\
\hline ADS & Activity Data Sheet \\
\hline ALARA & As Low as Reasonably Achievable \\
\hline AMEM & Assistant Manager for Environmental Management \\
\hline ASER & Annual Site Environmental Report \\
\hline ASO & Analytical Services Organization \\
\hline BMAP & Biological Monitoring and Abatement Program \\
\hline BMPs & Best Management Practices \\
\hline CAA & Clean Air Act \\
\hline CEQ & Council on Environmental Quality \\
\hline CERCLA & Comprehensive Environmental Response, Compensation, and Liability Act \\
\hline COTR & Contracting Officer's Technical Representative \\
\hline $\operatorname{COR}(s)$ & Contracting Officer Representative(s) \\
\hline CSO & Cognizant Secretarial Offices \\
\hline D\&D & Decontamination and Decommissioning \\
\hline DOE & U.S. Department of Energy \\
\hline DOE-HQ & DOE Headquarters \\
\hline $\begin{array}{l}\text { DOE-O } \\
\text { DOE-ORO }\end{array}$ & $\begin{array}{l}\text { DOE-Oversight Division } \\
\text { US Denartment of Fnerov-Oak Ridoe Onerations }\end{array}$ \\
\hline DP & $\begin{array}{l}\text { Def. Department or Energy-Uak Ruage Uperations } \\
\text { Defense Programs }\end{array}$ \\
\hline DP-1 & Office of the Assistant Secretary for Defense Programs \\
\hline EFPC & East Fork Poplar Creek \\
\hline EH & DOE Office of Environment, Safety, and Health \\
\hline EH-1 & Office of the Assistant Secretary for Environment, Safety, and Health \\
\hline ELMS & Environmental Laboratory Information Management System \\
\hline EMMIS & Environmental Monitoring Management Information System \\
\hline EMD & Y-12 Environmental Management Department \\
\hline EML & Environmental Measurements Laboratory \\
\hline EMP & Environmental Monitoring Plan \\
\hline ENVPD & DOE-ORO Environmental Protection Division \\
\hline Energy Systems & Lockheed Martin Energy Systems, Inc. \\
\hline EOC & Emergency Operations Center \\
\hline EPA & U.S. Environmental Protection Agency \\
\hline EPCRA & Emergency Planning and Community Right-to-Know Act \\
\hline EPPIP & Environmental Protection Program Implementation Plan \\
\hline ERD & DOE-ORO Environmental Restoration Division \\
\hline ER/WM & Environmental Restoration and Waste Management \\
\hline ESD & DOE-ORO Engineering Services Division \\
\hline ES\&H & Environment, Safety, and Health \\
\hline ESPQCP & Environmental Surveillance Procedures Quality Control Program \\
\hline ESWMO & Energy Systems Waste Management Organization \\
\hline FFA & Federal Facility Agreement \\
\hline FYP & Five-Year Plan \\
\hline
\end{tabular}




\section{Acronyms (cont.)}

\begin{tabular}{|c|c|}
\hline GWPP & Groundwater Protection Program \\
\hline HSEA & Health, Safety, Environment, and Accountability Organization \\
\hline MOA & Memorandum of Agreement \\
\hline NEPA & National Environmental Policy Act of 1969 \\
\hline NESHAP & National Emissions Standards for Hazardous Air Pollutants \\
\hline NOV & Notice of Violation \\
\hline NPDES & National Pollutant Discharge Elimination System \\
\hline NQA-1 & Quality Assurance Standards for Nuclear Facilities \\
\hline ODIS & On-Site Discharge Information System \\
\hline OMB & Office of Management and Budget \\
\hline OREIS & Oak Ridge Environmental Information System \\
\hline ORIG & Oak Ridge Implementation Guidance \\
\hline ORNL & Oak Ridge National Laboratory \\
\hline ORO & Oak Ridge Operations \\
\hline ORR & Oak Ridge Reservation \\
\hline OSHA & Occupational Safety and Health Act \\
\hline $\mathrm{PCB}(\mathrm{s})$ & Polychlorinated Biphenyl(s) \\
\hline PPAP & Pollution Prevention Awareness Program \\
\hline PPOA & Pollution Prevention Opportunity Assessments \\
\hline PSS & Plant Shift Superintendent \\
\hline QA & Quality Assurance Program \\
\hline QAMS & Quality Assurance Management Standards \\
\hline QAPP & Quality Assurance Project Plan \\
\hline $\mathbf{Q C}$ & Quality Control Program \\
\hline RCRA & Resource Conservation and Recovery Act \\
\hline RU/FS & Remedial Investigation/Feasibility Study \\
\hline SARA & Superfund Amendments and Reauthorization Act \\
\hline SCWR & Site Characterization and Worker Requirements \\
\hline SERC & Site Environmental Report Coordinator \\
\hline SPCC & Spill Prevention, Control, and Countermeasures \\
\hline SRC & Spill Response Coordinator \\
\hline SSPP & Site-Specific Plan \\
\hline SWMU & Solid Waste Management Unit \\
\hline TDEC & Tennessee Department of Environment and Conservation \\
\hline TDEC/DOE-O & $\begin{array}{l}\text { Tennessee Department of Environment and Conservation, DOE Oversight } \\
\text { Division }\end{array}$ \\
\hline TEMA & Tennessee Emergency Management Agency \\
\hline TOA & Tennessee Oversite Agreement \\
\hline TSCA & Toxic Substances Control Act \\
\hline UST & Underground Storage Tank \\
\hline WMD & DOE-ŌRO Waste Management Division \\
\hline WM\&TD & DOE Waste Management and Technology Development Division \\
\hline YSO & Y-12 Site Office \\
\hline
\end{tabular}




\section{PREFACE}

The U.S. Department of Energy (DOE) currently oversees activities on the Oak Ridge Reservation (ORR), a govemment-owned, contractor-operated facility. The three sites that compose the reservation (the Y-12 Plant, Oak Ridge National Laboratory [ORNL], and the K-25 Site) were established in the early 1940s as part of the Manhattan Project, a secret undertaking that produced the first atomic bombs. The primary missions of the three sites have evolved during the past 50 years and continue to adapt to meet the changing defense and energy needs of the United States, all the while dealing with a wide variety of operations and diversity of environmental, safety, and health challenges.

In March 1995, Lockheed and Martin Marietta completed a merger to create Lockheed Martin Corporation. Following the merger, Martin Marietta Energy Systems, Inc., the prime contractor for the ORR, was renamed Lockheed Martin Energy Systems, Inc. (Energy Systems).

In late 1995, the Lockheed Martin Corporation organized into several business sectors, each of which focused on a particular aspect of the company's business. As a result, the Energy and Environment Sector was formed. All of the company's DOE business became part of the sector. Furthermore, in August, the Energy and Environment Sector announced that ORNL would no longer be operated as part of the contract with the Y-12 Plant and K-25 Site under Energy Systems. Instead, Lockheed Martin Energy Research (LMER) Corporation was formed with the sole mission of operating ORNL for DOE. A contract was signed with DOE, effective January 1 , 1996, that transferred the responsibility for operating ORNL from Energy Systems to the newly formed LMER Corporation.

Three of the most significant challenges faced by the DOE facilities in Oak Ridge are to maintain scientific and technical excellence; increase productivity; and cut costs without compromising environment, health, and safety. Successfully dealing with such challenges calls for a philosophical change in business operations. At the national level, policy and strategy have been formulated calling for contract reforms and stakeholder involvement in shaping the future of the DOE mission. At the local level, DOE-Oak Ridge Operations personnel and their contractors are working to redefine local missions and refocusing technical capabilities and expertise to serve the nation and customers who are responsible to DOE. The $Y-12$ Plant continues to serve as a key manufacturing technology center for the development and demonstration of unique materials, components, and services of importance to DOE and the nation; yet, the Y-12 Plant is a center of change.

In December 1996, in an effort to reengineer Energy Systems and realign the environmental organizations with the reduced budgets and resources necessary to meet the challenges of the future, a unified Y-12 Plant and K-25 Site Environmental Compliance Organization was announced. This document has not been modified to reflect the new organizational structure since specific details of this organization have not been finalized.

In light of these ongoing changes, the reader of this EPPIP should bear in mind that the organization descriptions and responsibilities outlined in this document are subject to change during the coming year. 


\section{Environmental Protection Program Implementation Plan}

\section{DESCRIPTION OF THE ENVIRONMENTAL PROTECTION PROGRAM}

\subsection{GENERAL}

The Oak Ridge Y-12 Plant is located in the Bear Creek Valley of East Tennessee, adjacent to Oak Ridge, Tennessee (population 28,000), about 15 miles from Knoxville (Figure 1, "Maps showing location of the Y-12 Plant"). The plant occupies more than 800 acres, spanning $\mathbf{2 . 5}$ miles, with some $\mathbf{2 5 0}$ buildings that house about $\mathbf{7}$ million square feet of laboratory, machining, dismantlement, and research and development areas.

The Y-12 Plant is a government owned, Department of Energy (DOE) facility managed by Lockheed Martin Energy Systems, Inc. (Energy Systems), a subsidiary of Lockheed Martin Corporation.

The Y-12 Plant was constructed as part of the World War II Manhattan Project. Until 1992 the primary mission of the Y-12 Plant was the production and fabrication of nuclear weapon components. Activities associated with these functions included production of lithium compounds, recovery of enriched uranium from scrap material, and fabrication of uranium and other materials into finished parts for assemblies. Fabrication operations included vacuum casting, arc melting, powder compaction, rolling, forming, heat treating, machining, inspection, and testing. Because of the plant's work with radioactive components, many unique environmental challenges have arisen including how to dispose of "mixed waste" (hazardous radioactive) and how to reduce radionuclide air emissions.

Although mission emphases at the Y-12 Plant have evolved and changed with the easing of international tensions, the plant continues to serve as a manufacturing unit for the DOE as well as a key manufacturing technology center for the development and demonstration of unique materials, components, and services of importance to DOE and the nation. To facilitate this effort, the Oak Ridge Centers for Manufacturing Technology has been established at the Y-12 Plant. This facility comprises nine centers, each devoted to a specific area of research and manufacturing or measurement technologies. One center is devoted to Energy and Environmentally Conscious Manufacturing. The facility can produce comprehensive development studies, promote environmental management techniques, and develop pollution prevention and manufacturing technologies.

Personnel at the Y-12 Plant share the Energy Systems and DOE vision to be one of the best companies in the United States in developing and executing innovative and cost-effective environmental actions. We recognize that excellence in environmental protection and pollution prevention requires a program that exemplifies leadership and meets the intent as well as the letter of applicable requirements. Personnel at the Y-12 Plant have adopted a mission statement with the following phrase:

"We are recognized by our people, the community, and our customers as innovative, responsive, and responsible. We are a leader in worker health and safety, environmental protection, and stewardship of our national resources." 
ORNL-DWG PAN-8368R

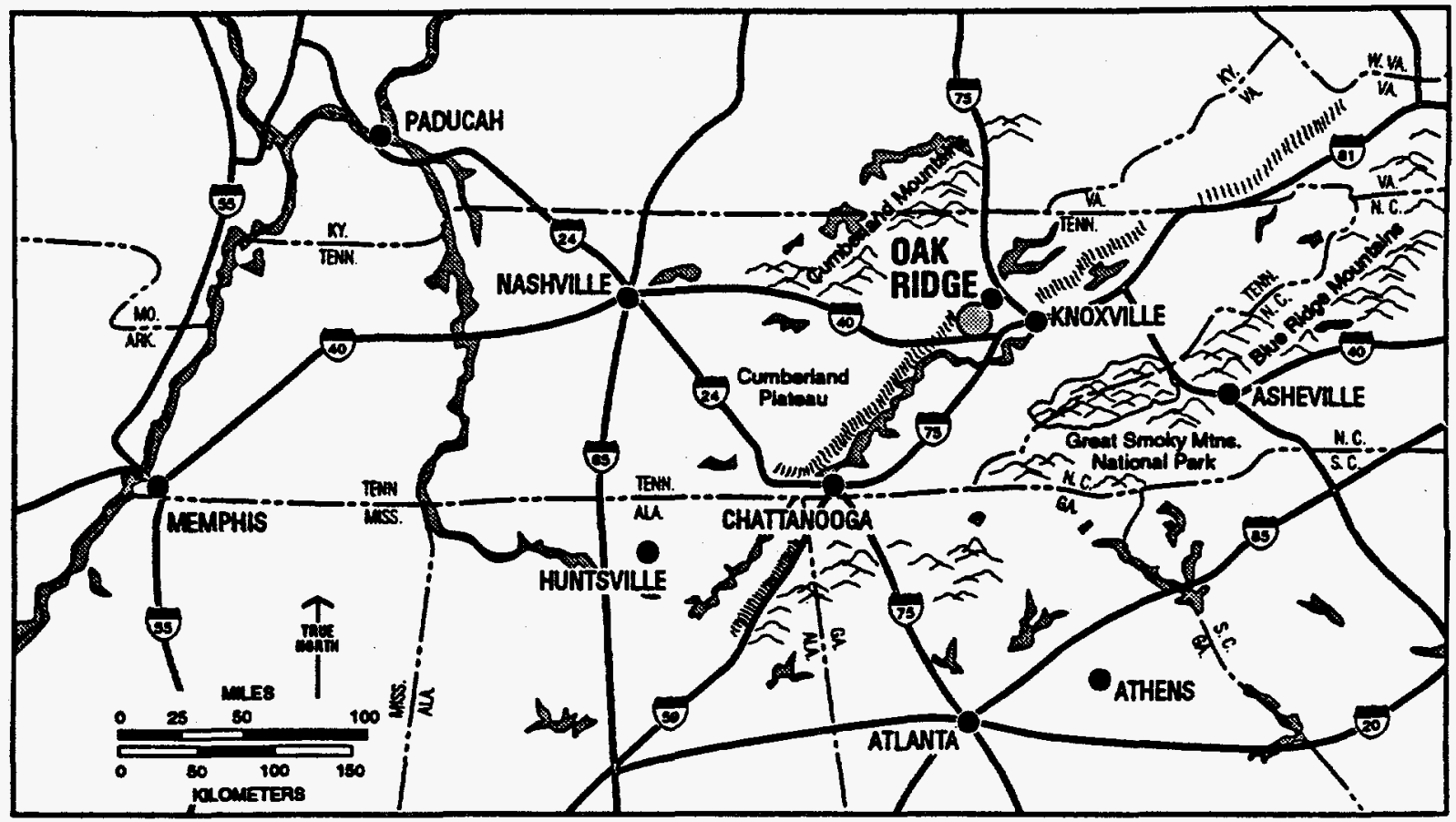

\section{LEGEND}

1IIIIII) Cumberland Escarpment

(6) Interstate Highway

(2.) Oak Ridge Reservation

State Line

ORNL-DWG 93M-9616

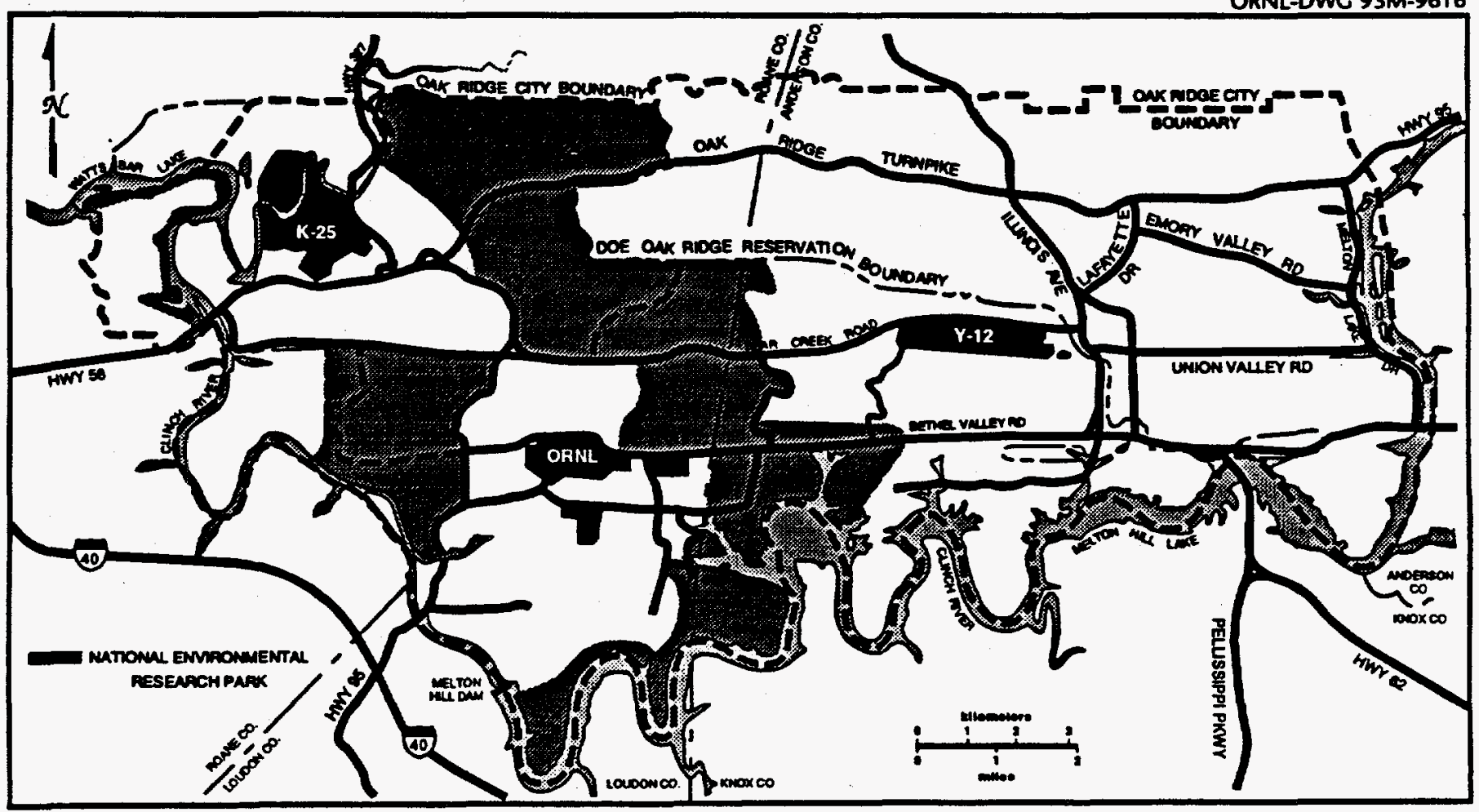

Fig. 1. Maps showing location of the Y-12 Plant. 
To this end, the Y-12 staff is committed to eliminating or reducing the amount of hazardous, mixed, radioactive, and nonhazardous waste generated in operations for which we are responsible. The commitment of each employee is the foundation of our pyramid for environmental excellence (see Figure 2).

The Y-12 Plant Environmental Protection Program is conducted to: (1) protect public health and the environment from chemical and radiological releases occurring from current plant operations and past waste management and operational practices; (2) ensure compliance with federal, state, and local environmental regulations and DOE directives; (3) identify potential environmental problems; (4) evaluate existing environmental contamination and determine the need for remedial actions and mitigative measures; (5) monitor the progress of ongoing remedial actions and cleanup measures; and (6) inform the public of environmental issues relating to DOE operations.

Success in meeting environmental objectives is assessed through comprehensive monitoring activities and a rigorous self-assessment program. Sampling/monitoring activities are needed to demonstrate compliance with permit limitations, ambient air and water quality standards, and other criteria associated with the protection of resources. Activities include collection of representative samples and accurate analysis of these samples to support (1) air and water effluent monitoring to determine compliance with applicable state and federal regulations and provide input data for dose assessment studies; (2) groundwater monitoring to determine compliance with the Resource Conservation and Recovery Act (RCRA), the Comprehensive Environmental Response, Compensation, and Liability Act (CERCLA), Underground Storage Tank (UST) regulations, and state solid waste regulations; (3) ambient surface water and air monitoring to assess the migration and effects of water and airborne contaminant releases to the off-site environment; and (4) monitoring of selected biological media to detect contaminant uptake, determine effluent toxicity, and assess the potential for entry into the food chain.

DOE Order 5400.1, General Environmental Protection Program, defines the general requirements for environmental protection programs at DOE facilities. This Environmental Protection Program Implementation Plan (EPPIP) defines the methods by which the Y-12 Plant staff will comply with the order by: (1) referencing environmental protection goals and objectives and identifying strategies and timetables for attaining them; (2) providing the overall framework for the design and implementation of the Y-12 Environmental Protection Program; and (3) assigning responsibilities for complying with the requirements of the order. The EPPIP is revised and updated annually.

DOE and Energy Systems are committed to achieving excellence, not just compliance, in the conduct of plant operations to ensure protection of the environment. To meet the challenges a.wociated with the changing mission of the Y-12 Plant, a rapidly changing regulatory environment, and tightly constrained resources, a structured process is necessary for allocation of resources in the most cost-effective manner so that this shared commitment may be achieved.

\subsubsection{Goals and Objectives}

Policy statements and strategic planning, which lead to goals and objectives, form the basis for program planning. In April 1994, the Secretary of Energy issued the strategic plan for DOE and identified environmental quality as one of five business areas. In May 1994, the Assistant 


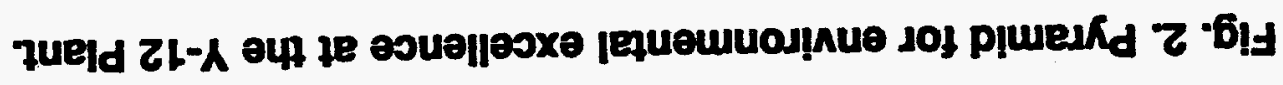

mul sostve VD-ג

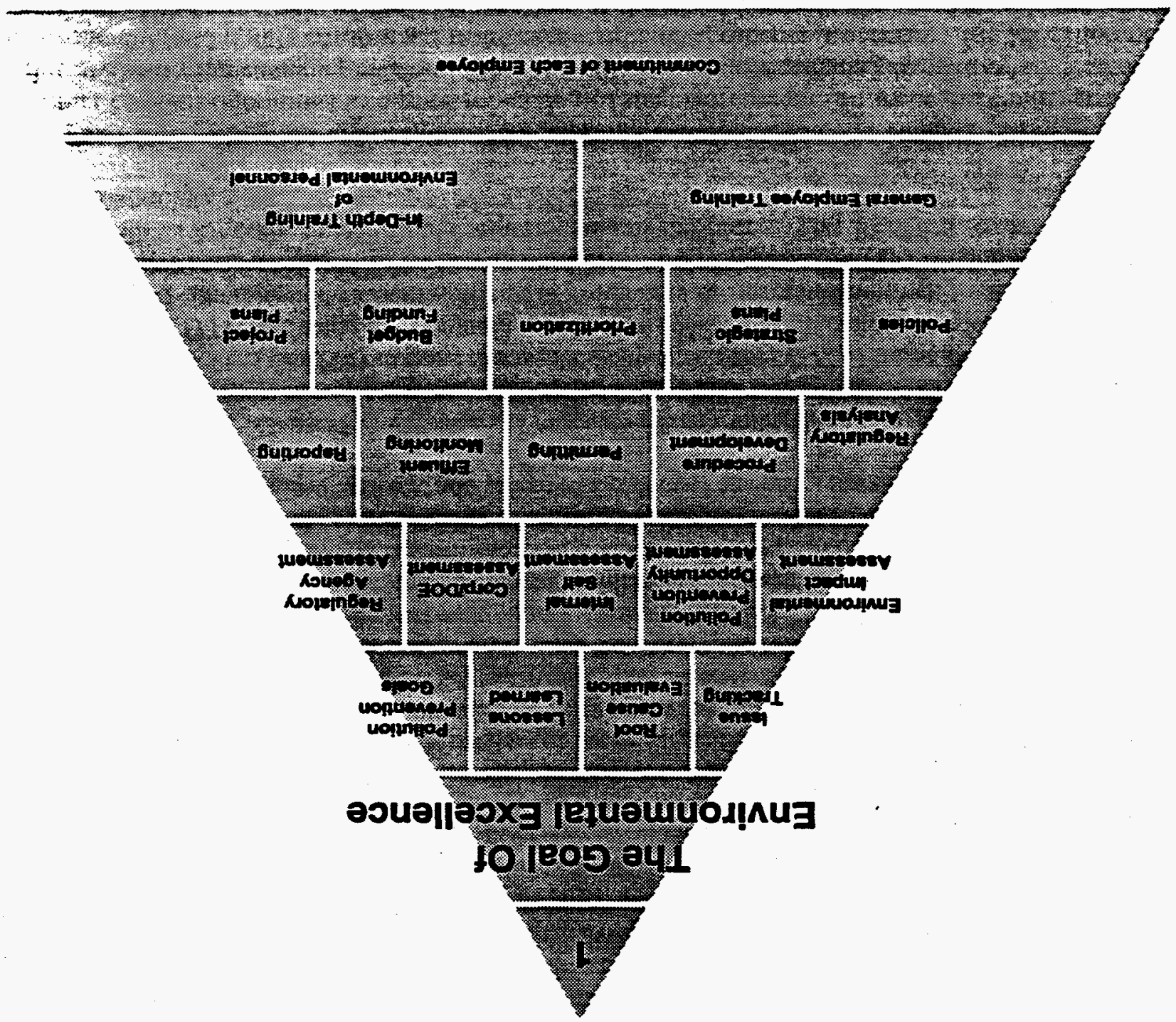


Secretary for Environmental Management issued the DOE Environmental Management Program Strategic Plan establishing key goals designed to lead the way to environmental excellence. To implement the strategic planning process at the local level, the Oak Ridge Environmental Management Strategic Plan was prepared, with input from community stakeholders. This plan formulates local strategies and approaches for implementing higher tier programmatic goals and strategies concerning environmental restoration and waste management activities on the Oak Ridge Reservation (ORR).

The DOE-Oak Ridge Operations (ORO) Environmental Protection Policy Statement that was issued by then DOE-ORO Manager Joe La Grone in April 1992, makes clear that protection of the public, the environment, and the employees at DOE facilities are responsibilities of paramount importance. In addition, DOE-ORO has issued a policy statement that each DOE and contractor organization shall plan and carry out a self-assessment program. The statement also defines program objectives.

The flow-down of additional applicable policy statements for the Y-12 Plant is noted below:

- Lockheed Martin Corporation, Corporate Policy Number CPS-015, Environment, Safety, and Health, September 14, 1995

- Lockheed Martin Energy Systems, Inc., Policy Number ES-EH-100, Revision 0, Energy Systems Environmental, Safety, and Health Policy Statement, November 15, 1991

- Y-12 Plant, Policy Number Y72-002, Policy for Environmental Protection, September 25, 1992

To further facilitate the implementation of DOE programmatic goals at the Energy Systems level, Energy Systems has developed and issued a strategic plan to provide a good foundation for building sound management action plans. The plan provides for the overall direction and guidance established by senior management from which all subsequent planning is based. The strategic planning process has led to several important goals and objectives, including:

- Achieve and maintain excellence through protection of the environment and full compliance with applicable environmental laws, regulations, orders, and agreements.

- Over the long term, achieve a minimum discharge operations in which raw and used materials are reduced at the source, reused, or recycled. Ensure that any remaining discharges to the air, water, or land are minimal and are not considered harmful to people or the environment.

- Ensure that risks to the environment and human health posed by past operations are either eliminated or reduced to prescribed levels through cost-effective clean up or containment.

- Enlist, empower, and support all Energy Systems personnel in the challenge of protecting the environment, conserving natural resources, preventing pollution, and complying with the applicable environmental laws, regulations, orders, and agreements.

- Increase the satisfaction of our customers and stakeholders and their confidence in Energy Systems in managing DOE facilities. Clearly understand their requirements and desires and strive to meet them. 
- Develop and maintain an Energy Systems-wide management system for environmental information.

- Continually improve the self-assessment process to identify issues, determine root causes, develop and validate corrective action plans, monitor progress, verify completion, identify trends, and document lessons learned.

- Help DOE ensure adequate environmental protection programs in all of its activities.

- Improve systems for dissemination of requirements by identifying needs for policies and procedures to implement applicable laws, regulations, orders, and agreements.

- Become recognized as an innovator in research and development, testing, demonstrating, and transferring new environmental sciences and technologies.

Those listed goals and objectives form the basis for planning and implementing a comprehensive environmental management system and audit program.

The DOE Y-12 Site Office (YSO), Environmental Restoration Division (ERD), Waste Management and Technology Development (WM\&TD), and Engineering Services Division (ESD) are responsible for administering the Y-12 Environmental Protection Program, and directing Energy Systems to execute environmental protection and compliance programs.

Responsibilities and authorities under DOE Order 5400.1, General Environmental Protection Program, and the actions that have been taken to meet the requirements, include the following:

1. Issue and update, as required, a general environmental statement that reflects the policy statement in this order and contains broad environmental protection goals for all facilities and activities for which špecific personnel are responsible.

The DOE-ORO Environmental Protection Policy Statement, dated April 9, 1992, issued by then DOE-ORO Manager, Joe La Grone, states that the site staff members are to conduct operations in a safe and environmentally sound manner, ensuring incorporation of all departmental and national environmental protection goals in the daily conduct of business. These goals are contained in federal statutes, executive orders, and DOE orders. A listing of DOE orders, key federal statutes, and executive orders is provided in Appendix A.

2. Ensure that all operations under DOE-ORO authority comply with applicable environmental protection laws, regulations, and directives. (See Appendix B.)

DOE-ORO, YSO, WM\&TD, and ESD ensure that all operations comply with all applicable environmental protection laws, regulations, and directives. Compliance with these requirements is documented in the ORR Annual Site Environmental Report (ASER).

Requests for exemptions from applicable environmental protection standards are not encouraged. However, in limited cases, programmatic circumstances or operational conditions may warrant such requests. Specific procedures for processing exemptions to standards are contained in federal, state, and local laws and regulations. Procedures for exemptions from standards that are internally imposed as a matter of DOE policy are detailed in Chapter I of DOE Order 5400.1, General Environmental Protection Program and Oak Ridge Implementation Guidance (ORIG) $5400.1 \mathrm{C}$. 
3. Identify significant environmental compliance issues that require resolution and coordination, and advise the Office of the Assistant Secretary for Environment, Safety, and Health (EH-1) and DOE-Headquarters (HQ) program personnel in a timely manner.

The DOE-ORO Contracting Officer Representatives (CORs), in conjunction with the Environmental Protection Division (ENVPD), identify significant environmental compliance issues that require resolution by the operating contractor and coordination with other governmental agencies. Issues requiring involvement of DOE-HQ receive high priority and are coordinated with the DOE Office of Defense Programs (DP), Environmental Management Division, and EH-1.

4. Ensure that all required environmental permits are secured from the appropriate regulatory agency in a timely fashion. Consistent with the requirement of DOE Order 5400.2R, Environmental Compliance Issue Coordination, in negotiating the terms and conditions of permits, settlements, consent orders, consent decrees, and other legal or administrative documents, every effort shall be made to ensure that permit requirements and conditions reflect the requirements of environmental regulations, consistent with national security interests, and are cost-effective.

The DOE-ORO CORs are responsible for ensuring that all required environmental permits are secured from the appropriate regulatory agency. The responsible COR negotiates the terms and conditions of permits, consent orders, and consent decrees, or other legal or administrative documents with regulatory agencies and site coordinators.

5. Conduct environmental appraisals of programs, projects, and facilities in accordance with DOE Order 5482.1D, Environment, Safety, and Health Appraisal Program, and other environmental safety and health requirements, and provide copies of appraisal reports to EH-1 and appropriate program office personnel.

Through the DOE-ORO CORs, all programs, projects, and facilities are reviewed in accordance with DOE Order 5482.1D, Environment, Safety, and Health Appraisal Program, and other environmental, safety, and health requirements. Self-assessment program plans have been developed by DOE-ORO and implemented by the CORs. Copies of all appraisal reports are supplied to DOE-HQ and appropriate program office personnel.

6. Establish and maintain liaison and cooperative programs with appropriate federal, regional, state, and local environmental officials to facilitate effective environmental management.

DOE-ORO interfaces with the appropriate federal, state, and local officials on environmental compliance and protection issues. An oversight agreement has been developed with the state of Tennessee that involves day-to-day interactions with the regulators. Periodic meetings are also held jointly with the Environmental Protection Agency (EPA) and the Tennessee Department of Environment and Conservation (TDEC).

7. Develop and implement programs that direct contractors to execute environmental protection compliance programs and policies and provide for oversight, confirmation, and independent verification of those contractor programs.

The DOE-ORO CORs instruct their contractors to implement independent monitoring programs to conduct surveillances and appraisals providing for oversight, confirmation, and independent verification of the contractor programs. 
8. Prepare long-range environmental protection plans in accordance with guidance issued by EH-1.

Based on guidance from DOE-HQ (R. E. Pelletier to distribution, "Clarification of the Environmental Protection Implementation Plan Guidance," October 16, 1989) the Environmental Restoration and Waste Management (ER/WM) Five-Year Plan (FYP) and the Environment, Safety, and Health (ES\&H) FYP satisfy the requirement for a Long-Range Environmental Protection Plan.

9. Ensure that budget requests provide for timely required environmental protection upgrades and corrective actions, and that budgets are consistent with pollution abatement plans prepared as required by U.S. Office of Management and Budget (OMB) Circular A-106.

DOE-ORO requests funding for environmental protection upgrade and correction activities. DOE-ORO ensures that these requests are consistent with pollution abatement plans prepared by contractors (as required by OMB Circular A-106). Budget requests for ES\&H issues are given a high priority by DOE-ORO.

10. Prepare biannual pollution abatement plans (as required by OMB Circular A-106) and submit to EH-1 on a schedule that is provided by that office.

The responsibility for preparation of OMB Circular A-106 responses for the Y-12 Plant is assigned to the DOE-ORO Planning and Budget Division, and is coordinated with the CORs. The process is discussed in Sect. 3.3 of this document.

11. Provide EH-1 with all of the environmental information and documentation that is requested.

Requests from EH-1 are coordinated by the respective program office in DOE-HQ, which works with DOE-ORO CORs to provide information on environmental issues.

12. Curtail or suspend an operation that poses a clear and present danger to a member of the public or the environment.

DOE-ORO CORs have the authority and responsibility to curtail or to suspend any operation that poses a clear and present danger to members of the public or the environment.

13. Provide for community public information and education programs concerning DOE environmental protection programs, consistent with the requirements of environmental protection regulations and national security interest.

DOE-ORO and the Public Information Office provide information and educational programs concerning DOE-ORO environmental protection programs. Several programs are implemented that involve local schools. Public meetings are held routinely to enhance public awareness of environmental restoration activities to meet regulatory requirements. To meet the general public's informational needs, DOE-ORO maintains a public reading room and information center.

\section{ORGANIZATION, ROLES, AND RESPONSIBILITIES}

DOE-ORO has overall responsibility for all environmental monitoring, compliance, and protection activities at the Y-12 Plant. It also has responsibility for developing and issuing a general environmental statement that reflects the policy statement in DOE Order 5400.1, General Environmental Protection Program. This DOE order contains broad environmental protection goals for all facilities and activities. Energy Systems publishes implementing procedures for executing environmental programs that comply with the requirements of the order. 
Within DOE-ORO, there are four organizations (YSO, ERD, WM\&TD, and ESD) with contractual relationships with DOE prime contractors on-site. The DOE-ORO COR provides direction and supervision to the contractors. There are also DOE-ORO matrix support organizations, such as ENVPD, which lend technical and administrative support to each of the above organizations. These relationships and communication links are depicted in Figure 4.

To clarify roles and responsibilities within DOE-ORO, Oak Ridge Implementation Guidances (ORIGs) for the implementation of DOE orders have been issued. Figure 3 lists applicable ORIGs for major DOE orders.

\begin{tabular}{|l|l|}
\hline \multicolumn{1}{|c|}{$\begin{array}{c}\text { Applicable } \\
\text { ORIG }\end{array}$} & \multicolumn{1}{c|}{ Name } \\
\hline 5400.1C & General Environmental Protection Program \\
5400.2B & Environmental Compliance Issue Coordination \\
5400.4A & $\begin{array}{l}\text { Comprehensive Environmental Response, Compensation, and Liability Act } \\
\text { (CERCLA) Requirements }\end{array}$ \\
5400.5B & Radiation Protection of the Public and Environment \\
N5440.1C & National Environmental Policy Act Compliance Program \\
5480.1D & Environment/Safety/Health Program for Oak Ridge Operations \\
Chg 1 & Environmental Protection, Safety, and Health Protection Standards \\
5480.4B & Environment/Safety/Health and Quality Assurance \\
5482.1D & Environmental Protection, Safety, and Health Protection Information \\
N5484.1A & Reporting and Requirements \\
5820.2B & Radioactive Waste Management \\
\hline
\end{tabular}

Fig. 3. Oak Ridge Implementation Guidance for major DOE orders on environmental quality and waste management.

These ORIGs correlate to DOE orders by assigning program responsibility and accountability providing administrative or contractual guidance to DOE-ORO and its contractors. OP :G 5400.1C, General Environmental Protection Program, is Appendix C. 


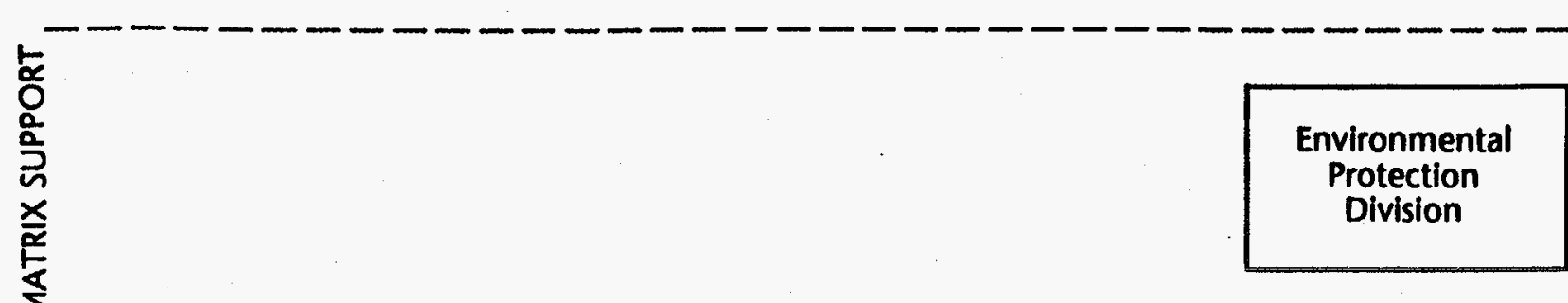

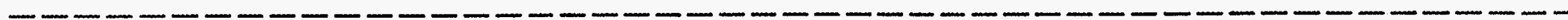

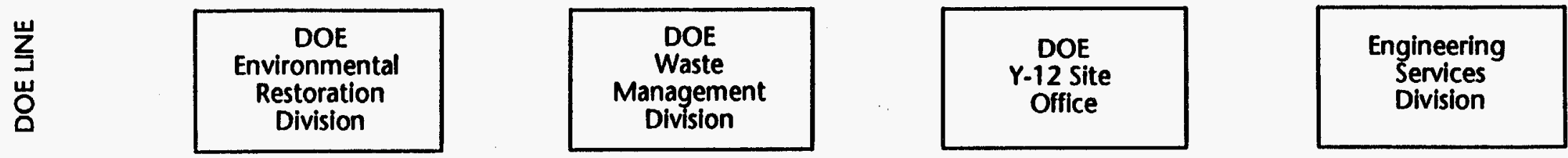

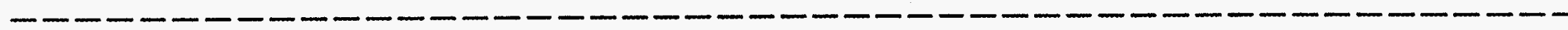

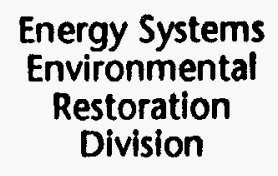

\begin{tabular}{|c|}
\hline Energy Systems \\
Waste \\
Management \\
Organization
\end{tabular}

Management

Organization
Energy Systems

Environmental

Management

Department
MK-Ferguson Johnson Controls

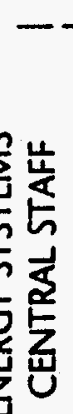

Energy Systems Central

Environmental Compliance Waste Management Environmental Restoration

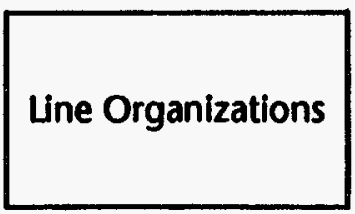

$X-10$ at $Y-12$

Fig. 4. DOE/Energy Systems communication matrix. 


\section{DOE Oak Ridge Operations Office}

\section{Y-12 Site Office}

The DOE-ORO YSO is managed under the direction of the DOE Y-12 Site Manager (see Figure 5). These YSO personnel serve as the site landlord and manager of site operations and have the responsibility for all activities conducted at the Y-12 Plant, with the exception of waste management and environmental restoration activities conducted under the Assistant Manager for Environmental Management (AMEM). These responsibilities include environmental matters related to operating facilities and related environmental control equipment, such as waste related surge and accumulation tanks located within each production facility that generates waste, operations and maintenance of interim waste storage facilities (satellite and 90-day waste accumulation areas) located within production facilities, management of petroleum UST compliance activities at the plant, overall management and coordination of sitewide permit administration, such as the National Pollutant Discharge Elimination System (NPDES) permit and air emissions permits for the site, and other sitewide environmental programs. The YSO is responsible for the development and prioritization of budget requests related to environmental monitoring and management of the sitewide environmental program, with the exception of those facilities or programs that are related to the mission of environmental restoration and waste management. The YSO also provides coordination and submittal of regulatory documents related to production facilities or sitewide permits.

\section{Environmental Restoration and Waste Management Organization}

The DOE-ORO ER/WM was formed in October 1989 and is under the direction of the AMEM. The organization was formed primarily to centralize project management and administrative activities associated with remedial actions and waste management, which had previously been managed on a site-specific basis under the purview of the CORs. This centralized structure improves the efficiency in which remedial actions are evaluated and implemented, and provides a greater consistency and uniformity in the management of wastes produced by current and past DOE operations.

Environmental Restoration and waste management activities at the Y-12 Plant are managed by the DOE-ORO Environmental Restoration Division and DOE-ORO Waste Management Division (see Figure 6). General responsibilities of the AMEM organization include:

1. Management of ERD activities, including: (1) development and prioritization of budget requests, remedial investigations, development of work plans and remedial action alternatives; (2) preparation and submittal of regulatory documents related to remedial actions; and (3) ensuring that appropriate ES\&H procedures are followed at sites undergoing remedial investigation/remedial action.

2. Management of dedicated waste treatment, storage, and disposal facilities, including: (1) program execution, development and prioritization of budget requests, (2) preparation and submittal of regulatory documents related to WMD activities, and (3) ensuring that appropriate ES\&H procedures are followed at Y-12 Plant WMD facilities. 


\section{Y-12 SITE OFFICE}

\section{Office of Site Manager}

Supervisory General Engineer

Secretary (Steno)

Sr. Nuclear Engineer

Fin./Admin. Specialist

General Engineer

General Engineer

General Engineer

General Engineer

"Student Trainee

\begin{tabular}{|l|}
\hline Program Management Branch \\
\hline Supervisory General Engineer \\
Secretary \\
General Engineer \\
General Engineer \\
General Engineer \\
General Engineer \\
General Engineer \\
Program Analyst \\
Program Analyst \\
Program Analyst \\
Program Analyst \\
Production Controller \\
\hline
\end{tabular}

\begin{tabular}{|l|}
\hline \multicolumn{1}{|c|}{ ES\&H } \\
\hline Supervisory General Engineer \\
Secretary \\
Nuclear Engineer \\
Health Physicist \\
Industrial Hygienist \\
Env. Engineer \\
Env. Engineer \\
Env. Scientist \\
Safety/Occ. Health Manager \\
Safety/Occ. Health Specialist \\
General Engineer \\
Program Analyst \\
\hline
\end{tabular}

Fig. 5. DOE Y-12 Site Office organlzational chart. 


\section{DOE-ORO Environmental Restoration and Waste Management Divisions}

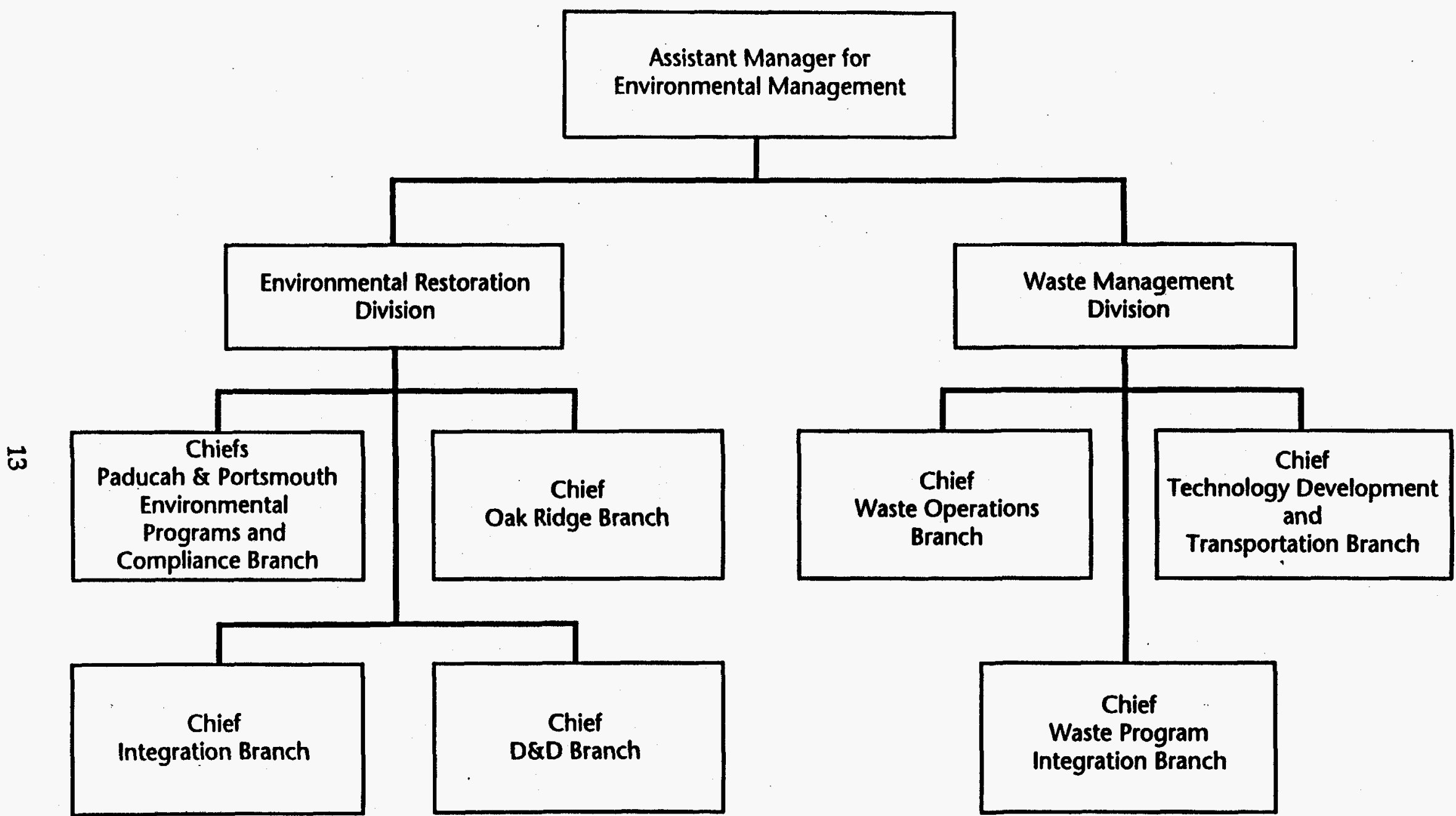

Fig. 6. DOE-ORO Environmental Restoration and Waste Management Divisions organizational chart. 
The DOE management and direction of the Y-12 Waste Management Program is affected by DOE WMD, through the Energy Systems Waste Management Organization (ESWMO).

Under the AMEM, ERD has responsibility for the oversight of environmental restoration activities, including site remediation and decontamination and decommissioning (D\&D) activities.

WMD is responsible for the management and oversight of the proper disposal of all wastes generated at the plant. These wastes include solid, hazardous, polychlorinated biphenyls (PCBs), radioactive, and mixed wastes. This responsibility is described in the Memorandum of Agreement (MOA) between the AMEM (formerly Assistant Manager for Environmental Restoration and Waste Management) and YSO that was prepared to define the roles and responsibilities of the AMEM and the Y-12 Site Manager in the environmental restoration and waste management activity and technology areas. In general, AMEM is responsible for all waste management and environmental restoration activities, including the Remedial Investigation/Feasibility Study (RI/FS) process and D\&D activities.

\section{Engineering Senvices Division}

DOE ESD is responsible for the contractual relationship, oversight, and interface with DOE prime contractors. MK-Ferguson, formerly a DOE prime contractor, now works as a subcontractor to Energy Systems. Johnson Control World Services remains as a prime contractor to DOE. Although these contractors are not specifically involved with the Y-12 Plant operations, they are housed at the site. MK-Ferguson has construction responsibilities at the site.

\section{DOE-ORO Environmental Protection Division}

ENVPD provides oversight, confirmation, and independent verification of environmental protection programs, and lends technical support to implement the requirements of DOE Order 5400.1, General Environmental Protection Program. Responsibilities and authorities for ENVPD in the implementation of DOE Order 5400.1 are noted in ORIG 5400.1 and explained below:

1. Conduct, as requested by the COR, independent oversight of Oak Ridge contractor environmental protection programs for (1) compliance with DOE and regulatory requirements, (2) technical adequacy and cost-effectiveness to aid the COR in the performance of his/her duties, and (3) an independent assessment of environmental performance for the DOE-ORO manager. This oversight includes (1) conducting the Environmental Protection Appraisal Program requirements of DOE Order 5482.1B, Environmental, Safery, and Health Appraisal Program, (2) reviewing for technical and regulatory aspects DOE-ORO environmental protection programs and documentation, and (3) participating in DOE, contractor, and regulatory agency meetings.

2. Provide technical support to the Y-12 Plant COR, as requested, to accomplish environmental protection program objectives.

3. Provide technical guidance relating to the National Environmental Policy Act (NEPA) program.

4. Provide counsel to the DOE-ORO manager's office on issues relating to the site environmental program. 
5. Assist in providing EH-1 with all requested environmental information and documentation.

6. Provide 24-hour, year-round support to the Oak Ridge Emergency Operations Center (EOC) personnel in matters relating to environmental incidents and releases.

Additional responsibilities include: (1) ensuring that the site environmental protection program is adequate to protect public health and the environment; (2) ensuring oversight, confirmation, and independent verification of contractor programs; (3) providing the Office of the Assistant Secretary for Defense Programs (DP-1) with all environmental information and advising on issues that are related to the site Environmental Protection Program.

Figure 7 presents an organizational chart of the DOE-ORO ENVPD. The ENVPD is divided into two branches, the Environmental Operations Branch and the Environmental Remediation Branch. Key personnel and areas of responsibility for the Environmental Operations Branch and the Environmental Remediation Branch are shown in Figure 7.

\subsection{DOE Contractor Organization and Responsibilities}

\section{Energy Systems}

Energy Systems is the primary contractor at the Y-12 Plant. Energy Systems has direct responsibility for operating and conducting Environmental Protection Program activities, including monitoring, laboratory analyses, data management, reporting, waste management, environmental restoration, and operation of waste treatment and pollution control systems. Energy Systems Central Engineering Services is responsible for providing project-specific subcontract requirements and certified-for-construction documents to MK-Ferguson for accomplishment of construction projects. Energy Systems operates as the facility manager to DOE for operation of Oak Ridge Plant sites. With respect to construction activities, Energy Systems is responsible to DOE for overall project management, periodically forecasting the construction work load, performance of DOE-designated Title III activities, and continuous operation and maintenance of the facilities.

Within Energy Systems, there are five organizations with primary responsibility for the management, implementation, and conduct of environmental program activities, including the requirements of DOE Order 5400.1, General Environmental Protection Program. These organizations are:

1. Environmental Management Department (EMD) of the Energy Systems Y-12 Health, Safety, Environment, and Accountability (HSEA) Organization;

2. Energy Systems Environmental Restoration Organization;

3. Energy Systems Waste Management Organization;

4. Energy Systems Environmental Compliance Organization; and

5. Energy Systems Y-12 Plant line operating organizations. 


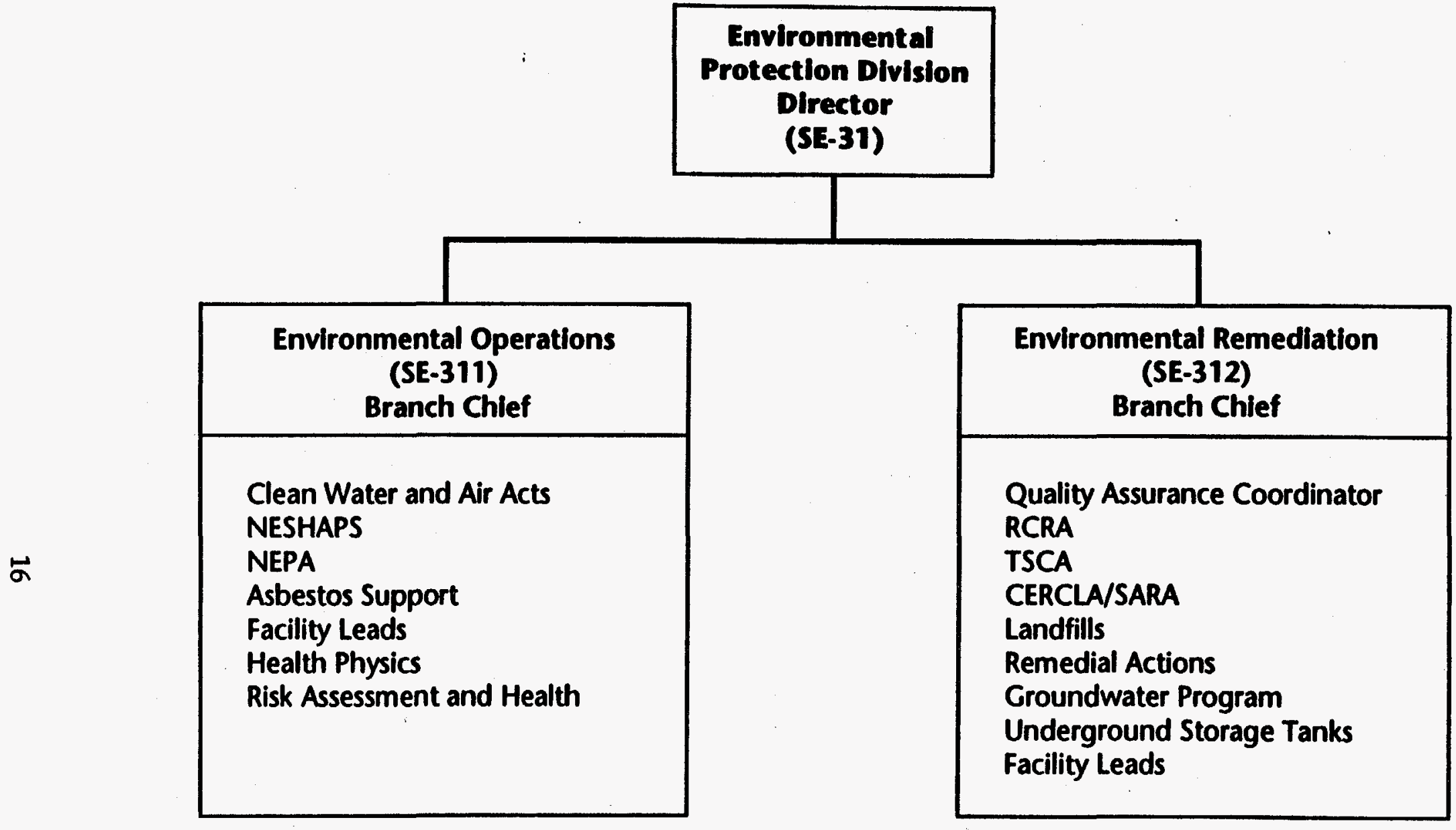

Fig. 7. Key personnel and areas of responsibility for the Environmental Operatlons Branch and the Environmental Remediation Branch in the DOE-ORO Environmental Protection Division. 
In addition to the compliance organizations, there is a network of environmental officers, one officer for each major Y-12 line organization of the plant, who act as liaisons to Energy Systems EMD staff in matters pertaining to Energy Systems Environmental Compliance for their respective organizations.

\section{Energy Systems, Y-12 Envinonmental Management Department}

The EMD manager reports to both the HSEA Manager and the Director of Energy Systems Energy Systems Environmental Compliance Organization. EMD provides oversight, technical support, and coordination service to all Y-12 Plant managers to ensure that every activity conducted on the site is environmentally acceptable and in compliance with all applicable DOE, state, and federal regulations. The services are provided in accordance with Energy Systems policies and contract commitments and within the framework of DOE-supported programs and resources at the Y-12 Plant.

EMD is subdivided into five sections: Water Compliance Program; Clean Air Program; Compliance Monitoring Services; Compliance Integration; and RCRA/Hazardous Waste Program. Two staff positions, the Environmental Coordinator and the Program Manager for Data Quality, provide technical and administrative support. The responsibility for the environmental program planning, budgeting, reporting, and other technical and administrative support functions are shared between personnel in the EMD and the Compliance, Planning, and Resources Department of HSEA. Organizational structure and areas of responsibility are illustrated in Figures $\mathbf{8}$ and 9. Responsibilities and activities of each section are detailed below.

\section{Water Compliance Program}

1. Manage a Best Management Practices (BMPs) Program for the Y-12 Plant including: (1) management/approval of unpermitted water discharges, BMP plan review and compliance, and soil erosion controls, and (2) administration of a program for inspection of construction activities, general plant activities, pollution control facilities, and water resource areas for water pollution control and compliance with environmental regulations, with emphasis on BMPs, Spill Prevention Control and Countermeasures (SPCC), and compliance of construction activities with environmental regulations.

2. Manage compliance programs associated with the sanitary sewer system, assist the Y-12 Plant staff in maintaining compliance with the Oak Ridge sewer ordinance and pretreatment permit program, and administer sewer system configuration control and internal (inflowfinfiltration) permitting programs. Maintain secondary containment data base and provile technical assistance on monitoring requirements and flow measurements.

3. Provide technical support and guidance to the Y-12 Plant staff on water sources; wastewater treatment, collection, and discharges; storm water control; and drain system configuration. Implement and manage programs designed to mitigate area source pollution. Administer the stream management model, manage subcontracts and projects, and develop strategies related to nonpoint source pollution.

4. Provide spill response coordination for the Y-12 Plant. Manage spill control and prevention programs, promote spill prevention projects, keep the SPCC Plan current, and assist the Y-12 Plant staff in complying with spill control and reporting regulations. 


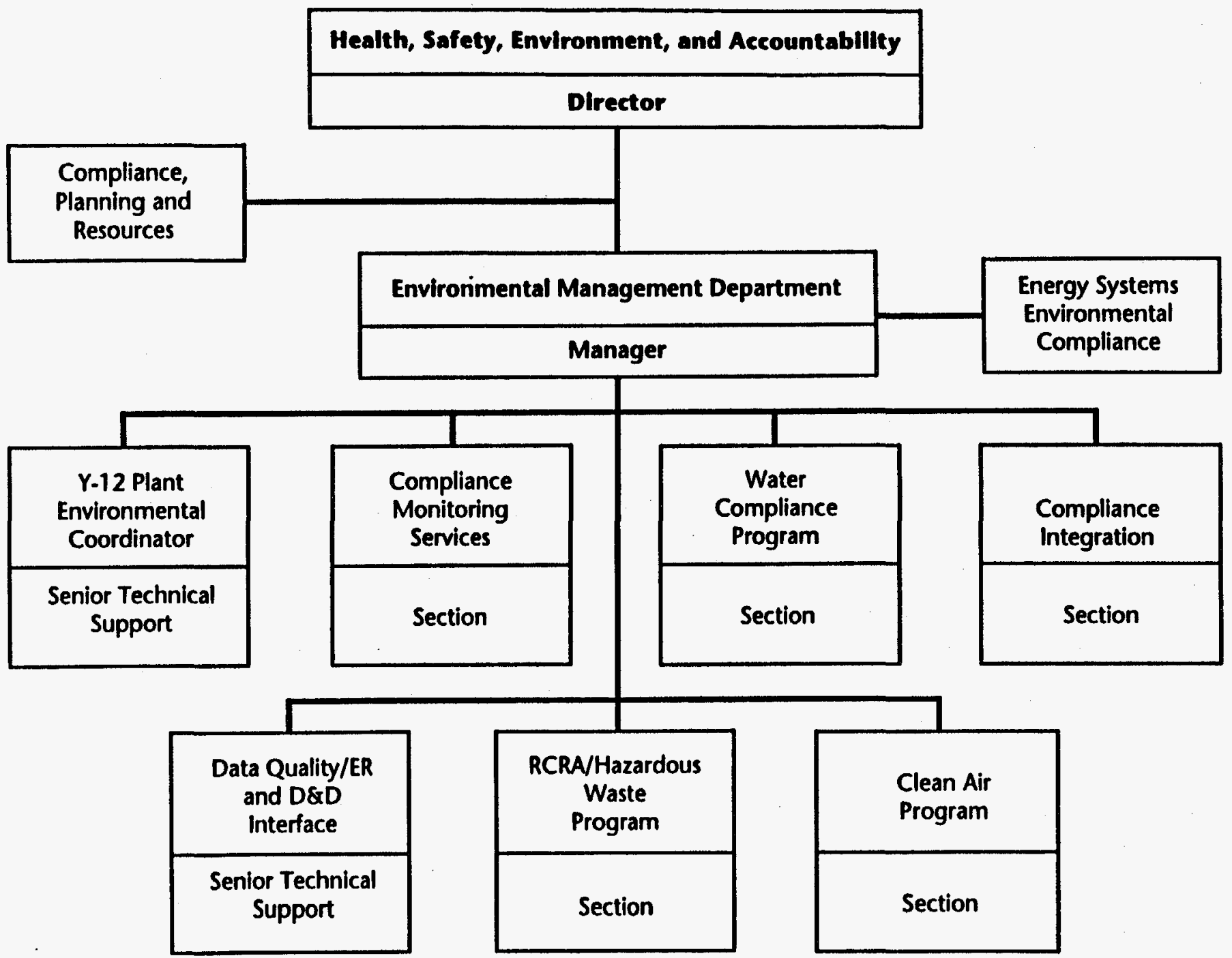

Fig. 8. Y-12 Plant Environmental Management organizatlonal chart (page 1 of 4). 


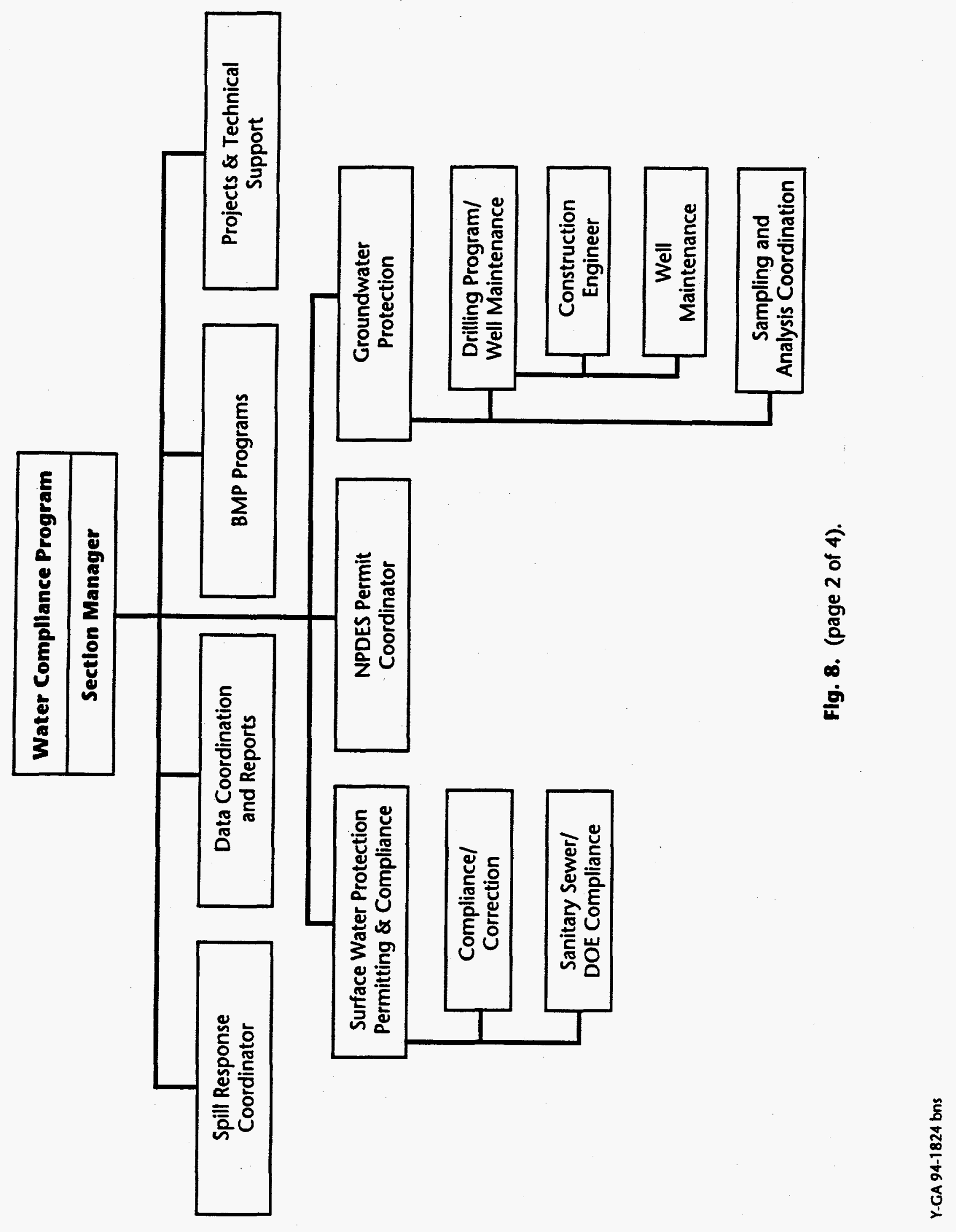




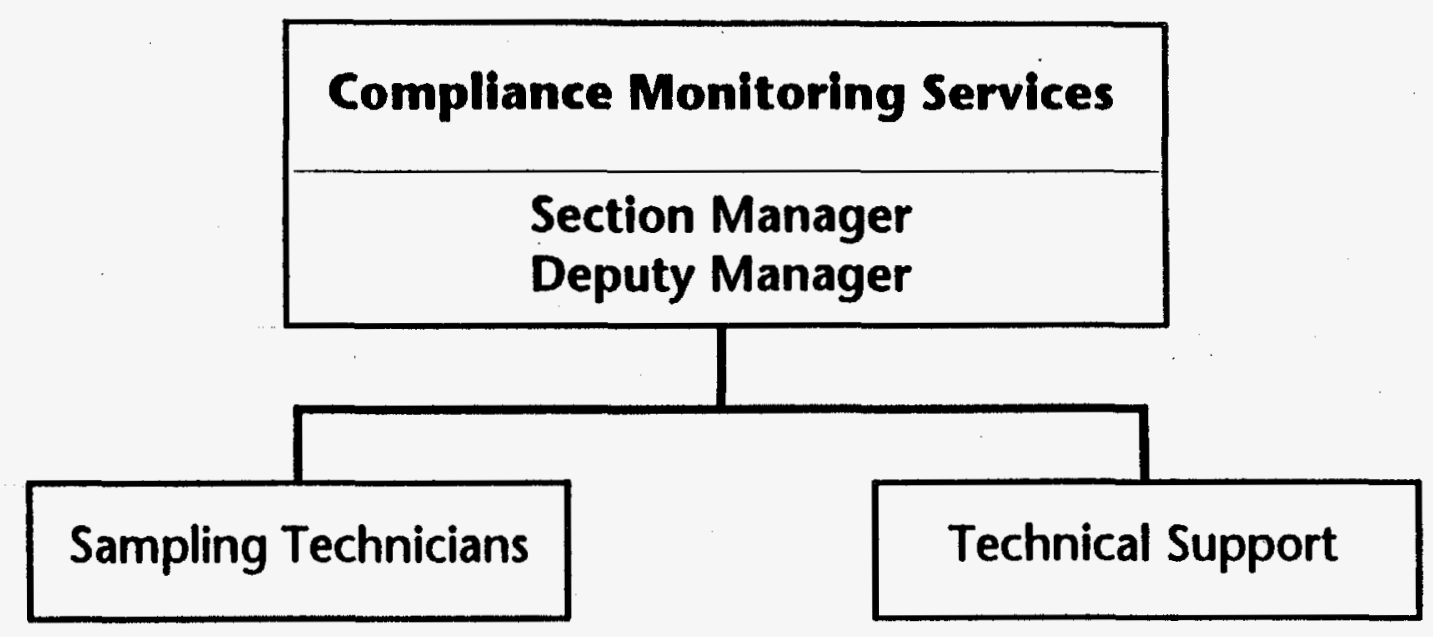

Fig. 8. (page 3 of 4). 

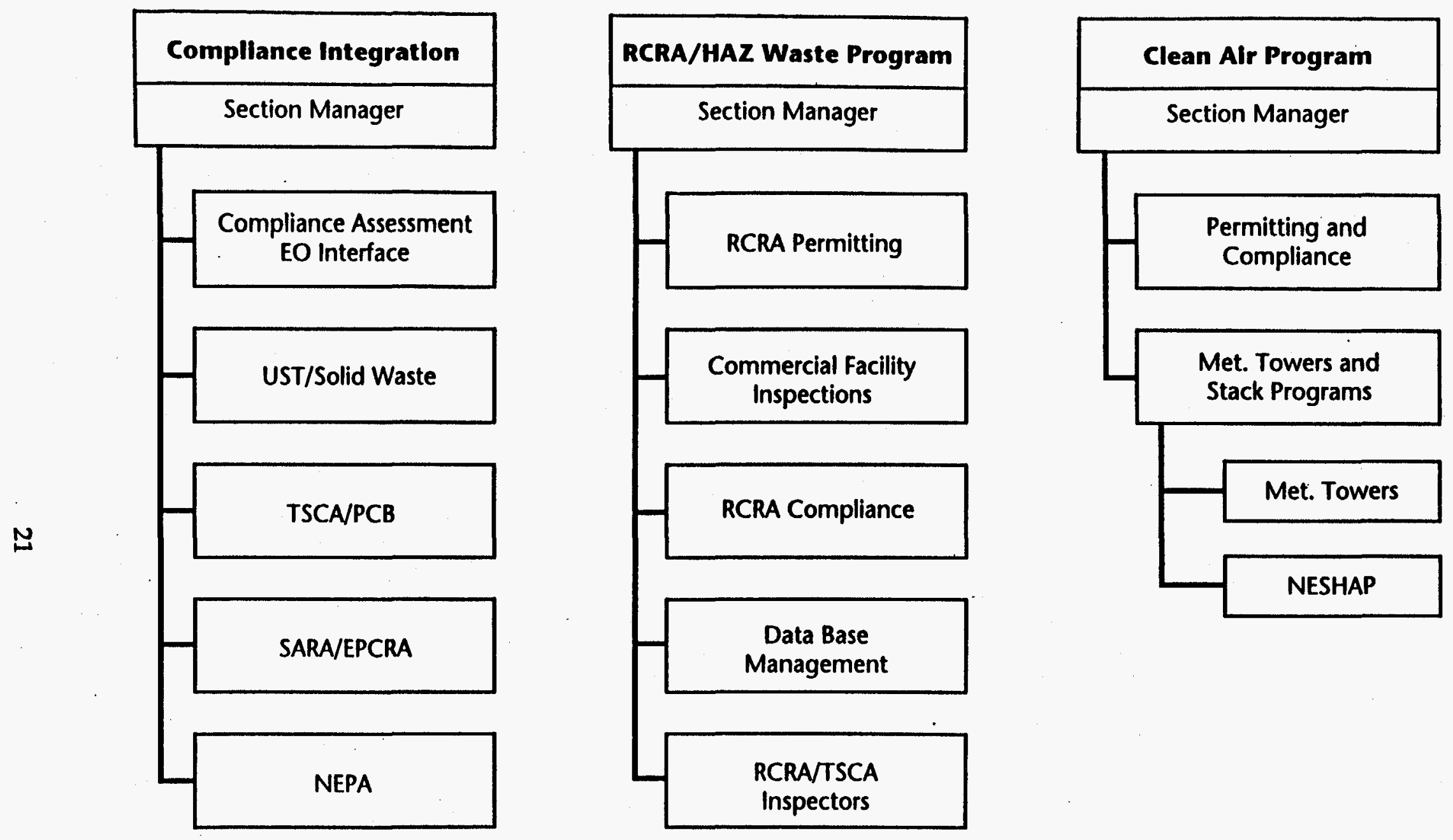

Fig. 8. (page 4 of 4). 


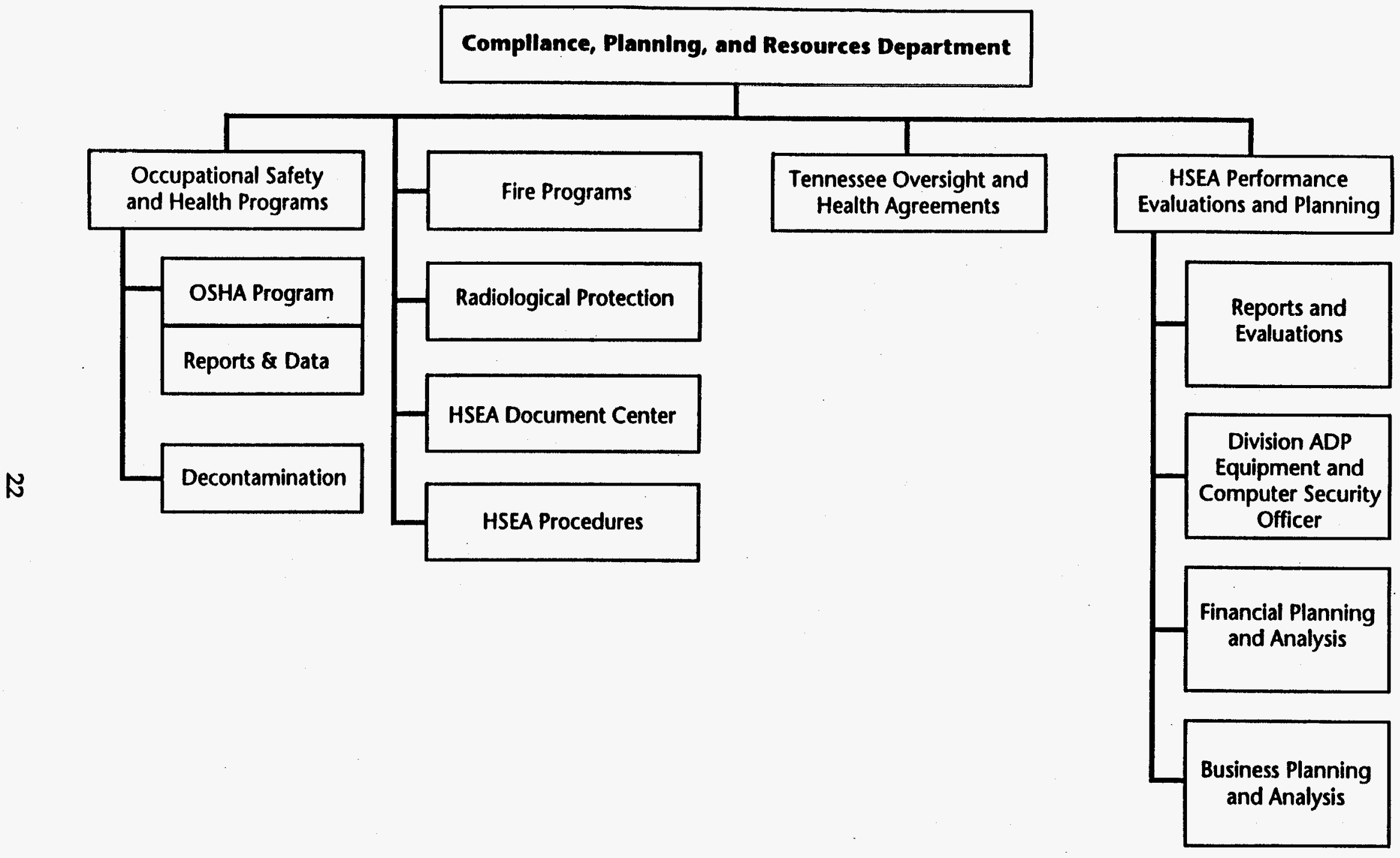

Fig. 9. Compllance, Planning, and Resources Department organization chart. 
5. Manage compliance programs associated with the NPDES permit, water quality and aquatic resources permits, Corps of Engineers permits, and DOE Order 5400.5, Radiation Protection of the Public and the Environment. Conduct investigation of Clean Water Act or permit noncompliances, and implement studies and programs related to water quality and aquatic resource protection.

6. Provide technical management for corrective action projects that relate to water pollution control.

7. Prepare and maintain environmental monitoring plans for surface water, NPDES discharges, and the sanitary sewer to meet objectives of permit requirements, BMPs, and the As Low As Reasonably Achievable (ALARA) Program. Prepare project-specific Quality Assurance Project Plans (QAPPs).

8. Prepare and implement the Y-12 Plant Groundwater Protection Program (GWPP) Management Plan. The purpose of the GWPP is to characterize the hydrogeology and monitor groundwater quality at the Y-12 Plant and surrounding areas. These tasks are conducted primarily in support of (1) environmental surveillance; (2) plant operations requiring groundwater monitoring under RCRA interim status, permits, or solid waste regulations; (3) UST investigations and corrective actions; and (4) maintenance and implementation of the Y-12 Plant Comprehensive Groundwater Monitoring Plan.

9. Coordinate preparation of the Y-12 Plant Clean Water monitoring reports as required by federal, state, and local regulations and DOE orders.

10. Provide resources for analyzing, reporting, and maintaining the Y-12 Plant environmental monitoring data base pursuant to applicable federal, state, and local regulatory requirements and DOE orders.

\section{Clean Air Program}

1. Provide technical support to operating organizations to ensure that atmospheric emissions are controlled to within Clean Air Act (CAA) emission standards and in compliance with the DOE ALARA policy. An overview of the ALARA policy is provided in Sect. 4.3 of this document.

2. Provide support to operating organizations for maintaining accurate, up-to-date air pollution permits and emission ledgers for all sources that emit contaminants into the atmosphere.

3: Conduct formal inspections and informal walk-throughs of permitted areas to ensure that operational and regulatory requirements are being met.

4. Develop the capability for air permit data bases to be accessed by operating organizations personnel in the plant so that expiration dates of permits may be tracked. Develop computer applications to assist in the generation of air permits.

5. Develop standards and procedures for the Y-12 Plant staff implementation of regulatory requirements and DOE orders.

6. Develop training programs for Y-12 Plant personnel, environmental officers, and operators to increase their overall awareness of the regulatory requirements of the CAA. 
7. Coordinate operation and maintenance of the Y-12 Plant Meteorological Information Support System.

8. Prepare and maintain environmental monitoring plans for stacks and ambient air to meet the objectives of permit requirements and BMPs. Prepare project-specific QAPPs.

Compliance Monitoring Services

1. In support of the Clean Air Program, conduct source emission testing (stack testing) and ambient air sampling to demonstrate compliance with the CAA.

2. In support of the Water Compliance Program, conduct sampling for compliance with the city of Oak Ridge Industrial Users Permit for the sanitary sewer system and the NPDES permit, which include wastewater characterization and routine effluent monitoring for specific parameters: biological, radiological, inorganics including metals, organics including PCBs, and toxicological.

3. Provide sampling support for the collection of environmental data to facilitate design, construction, and upgrade of plant facilities and utilities.

4. Provide environmental monitoring and sampling capability to support emergency response in the event of spills or other such releases of contaminants to the surrounding areas.

Compliance Integration

1. Coordinate $Y-12$ environmental compliance assessment activities of Y-12 Plant environmental programs.

2. Maintain tracking systems and evidence files for environmental compliance issues and assessment findings. Ensure that reporting requirements are met for issues and findings.

3. Ensure compliance with federal and state petroleum and hazardous substance UST regulations by providing direction for identification, assessment, and corrective measures.

4. Provide technical support for evaluating, assessing, and permitting of solid waste landfills.

5. Prepare NEPA documentation for all Y-12 Plant projects and activities, including compliance with the National Historic Preservation Act and other environmental laws.

6. Provise technical and programmatic interface with Y-12 Plant organizational environmental representatives (Environmental Officers).

7. Review proposed plant procedures for compliance with DOE orders and environmental regulations.

8. Prepare reports that are required by the Emergency Planning and Community Right-to-Know Act (EPCRA) in accordance with Executive Order 12856.

9. Prepare the PCB annual report, and provide technical support and compliance oversight to ensure that PCBs are managed in accordance with federal, state, and local regulations and with DOE orders. 


\section{RCRA/Hazardous Waste Program}

1. Provide oversight and technical input as required, including document preparation and review. Provide all pertinent guidance about RCRA compliance (i.e., current regulatory guidance on waste characterization and area operation) to area operators, environmental officers, and other Y-12 Plant personnel.

2. Conduct periodic, detailed inspections of all RCRA hazardous waste accumulation, storage, and treatment areas throughout the Y-12 Plant.

3. Prepare the federal and state regulatory compliance reports, such as the RCRA Annual Report and the Federal Facilities Biennial 3016 Report.

4. Prepare and maintain RCRA Part A and Part B permit applications. Request modifications to permits as required. Prepare contingency plan and closure plans.

\section{Compliance, Planning, and Resources Department}

1. Identify, implement, and facilitate effective reporting and evaluating systems for the Y-12 Plant environmental program.

2. Provide support to the business planning and budgeting process.

3. Ensure formulation and reporting of short- and long-range strategies, goals, and plans for Y-12 Plant environmental programs.

4. Assist in developing policies, procedures, and general and program-specific strategies for the submission of specific deliverables in conjunction with the other Oak Ridge sites to the DOE-Tennessee Oversight Agencies (TOA) Group.

\section{Environmental Restoration Organization/Program}

The Environmental Restoration Organization is an Energy Systems environmental organization with the responsibility for managing environmental cleanup activities at the Energy Systems-managed plants. including the Y-12 Plant. Program responsibility begins with the identification of remediation sites and extends until acceptance of a completed Record of Decision or upon regulatory agreement that the site requires no further action, as applicable. A chart illustrating this organization is provided as Figures 10 and 11.

\section{Energy Systems Waste Management Organization}

The purpose of the Energy Systems Waste Management Organization (ESWMO) is to integrate waste management operations across the sites managed by Energy Systems on the Oak Ridge Reservation. The Y-12 Plant Waste Management Organization manager reports directly to the Energy Systems Central Waste Management director. 


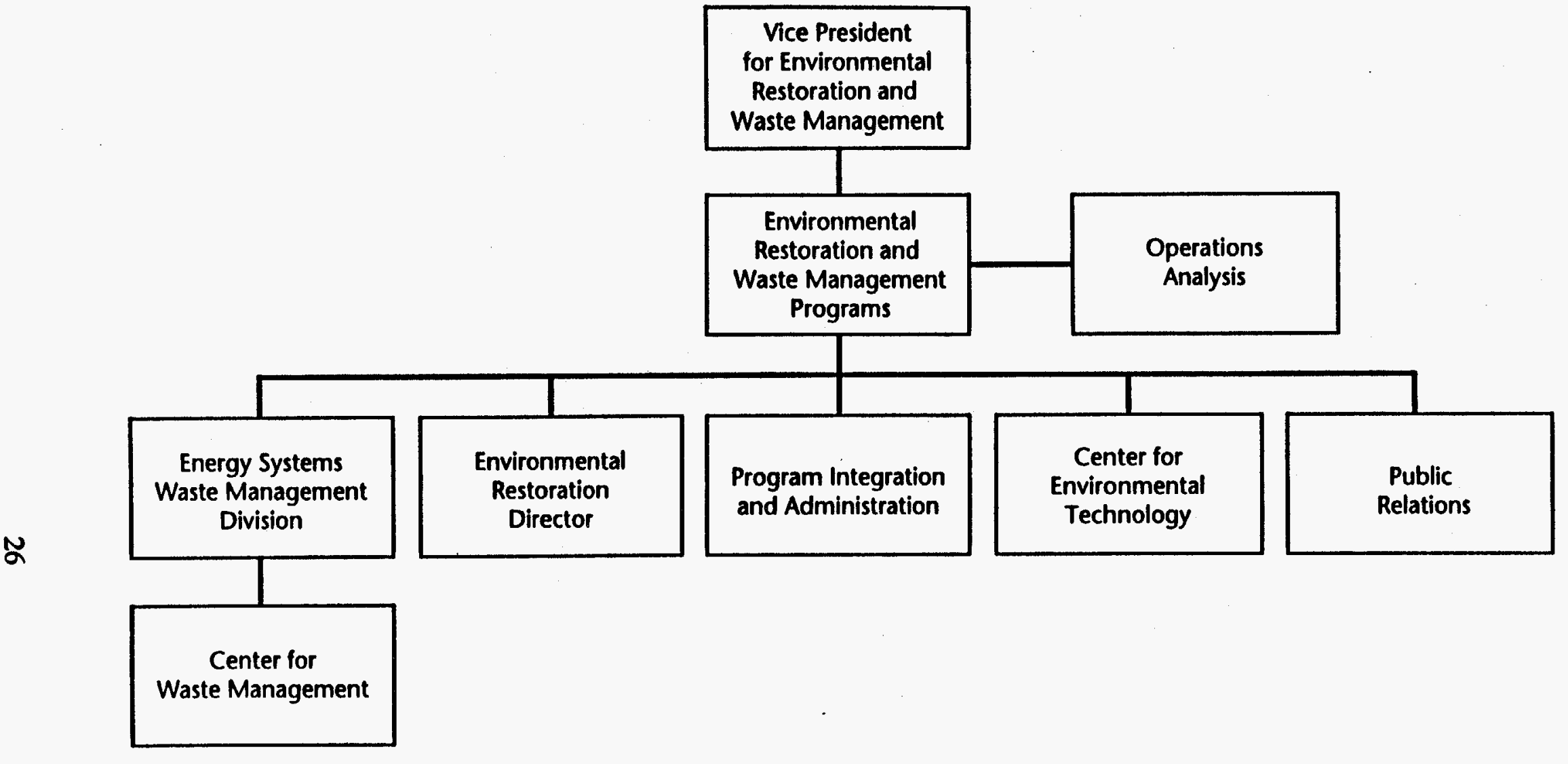

Fig. 10. Energy Systems Environmental Restoration and Waste Management organization chart. 


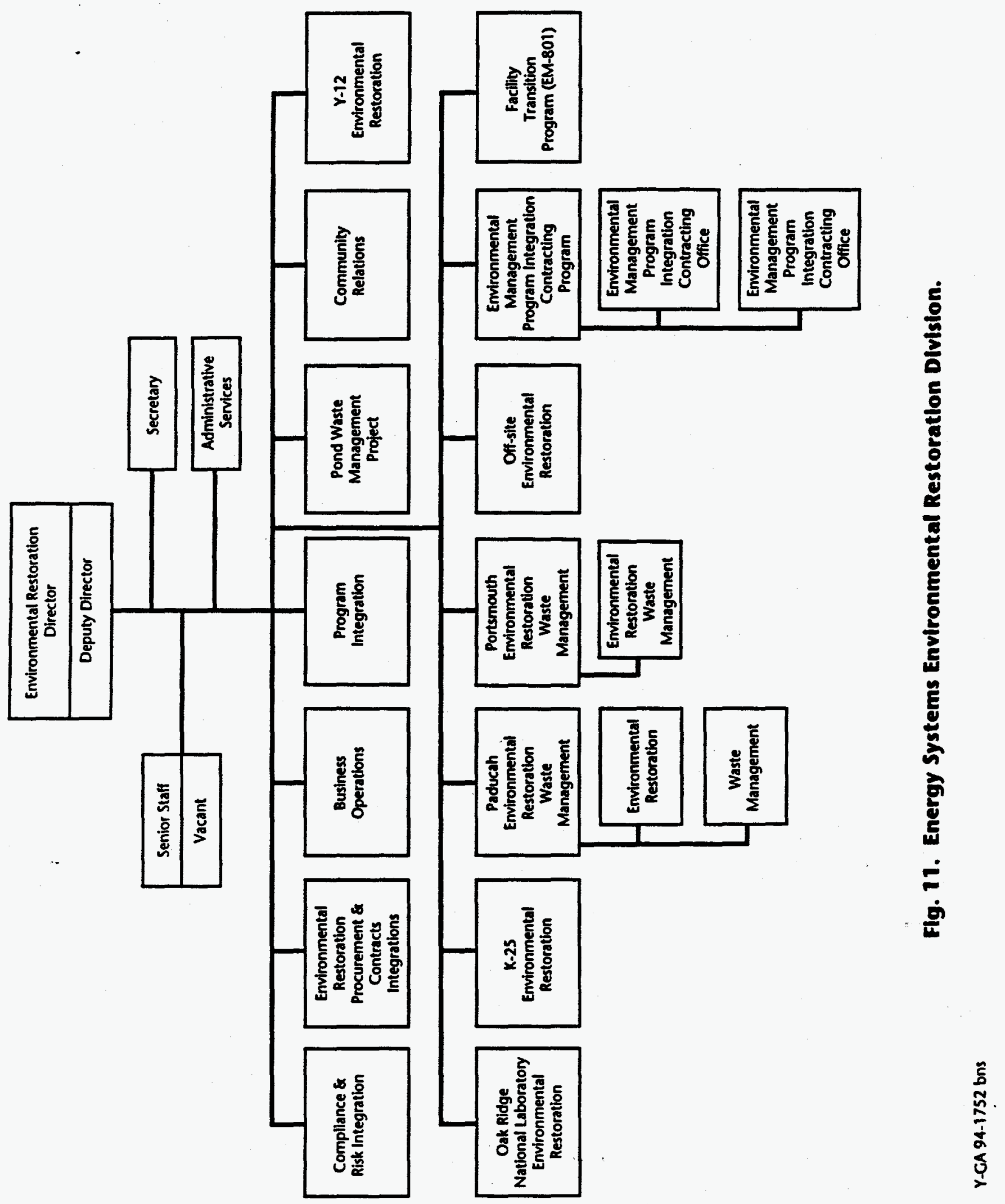


The Y-12 Plant Waste Management Organization is responsible for the safe and effective treatment, storage, and disposal of radioactive, hazardous, mixed, and sanitary wastes, including both liquids and solids. Another important function of this organization is the administration of the Waste Minimization Pollution Prevention Program, discussed in Sect. 4.2 of this document. The Y-12 Plant Waste Management Organization activities are managed in accordance with policies and directives established by the ESWMO. An organizational chart of the Y-12 Plant Waste Management Organization is provided as Figure 12. Specific responsibilities include:

1. Using treatment processes, such as sedimentation, compaction, bailing, neutralization, pH adjustment, biological, and dewatering, to provide a controlled conversion of plant waste streams from an environmentally unacceptable form to a form that is safer and more easily handled or stored.

2. Collecting, certifying/characterizing, and transporting of wastewater, solvents, oils, sludges, and other solids that are generated by active, ongoing Y-12 Plant operations. (Waste generators are responsible for initial waste characterization to satisfy established waste acceptance criteria.)

3. Transporting vessel maintenance, inspecting for transportation of containerized waste, and the waste generator-waste management interfacing, including communicating with waste generators to reduce, eliminate, and segregate wastes.

4. Providing interim management for storage of waste awaiting treatment or for which no disposal capabilities are available at present.

5. Handling wastewater, solvents, oils, sludges, and other solids for disposal (on-site and off-site) and operating and maintaining active disposal sites.

6. Monitoring and surveying facilities and equipment to ensure all regulations are met and there is no adverse impact on workers' health, the public health, or the environment.

7. Providing customer coverage for the conceptual and detailed design of new Waste Management facilities and systems necessary to meet changing plant needs. Providing oversight of construction for the above projects and formulating acceptance criteria for turnover of the finished product to ESWMO.

8. - Providing program management of Y-12 Plant D\&D activities.

9. Providing program management and coordination of plantwide pollution prevention activities.

10. Provide Program Management and reporting structure to meet milestones identified in the ORR Site Treatment Plan (STP) for the treatment and disposition of mixed wastes on the ORR. 


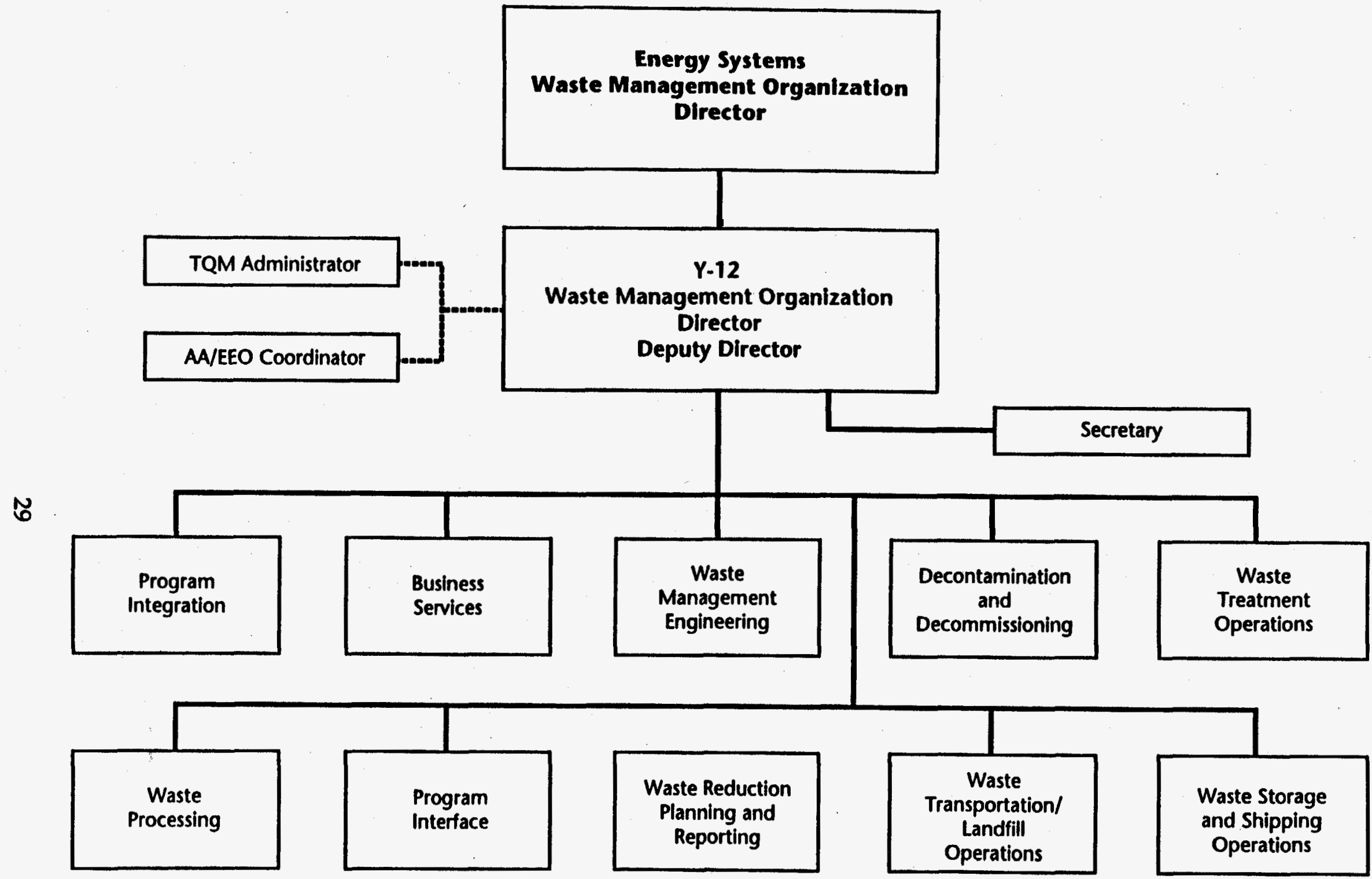

Fig. 12. Y-12 Plant Waste Management Organization. 


\section{Energy Systems Environmental Compliance Onganization}

This Energy Systems central environmental organization is responsible for internal oversight and coordination of Environmental Protection Program activities at the DOE-ORO facilities managed by Energy Systems staff. Responsibilities for this organization include:

1. Preparing and administering policies and procedures of Energy Systems for environmental protection programs that are consistent with state and federal laws and regulations, DOE orders, and corporate and company policies.

2. Reviewing and approving ongoing and proposed programs for compatibility with overall environmental goals and strategies of Energy Systems and for ensuring compliance with present and anticipated requirements.

3. Ensuring the interface of programs and environmental protection programs in conjunction with the director of Quality Assurance (QA), Energy Systems.

4. Coordinating the implementation of DOE Order 5400.1, General Environmental Protection Program, requirements at the DOE-ORO Energy Systems-managed plants to ensure uniformity and consistency in meeting environmental protection program objectives.

5. Determining, through the use of oversight and of internal evaluations, the status of each Energy Systems facility in complying with the requirements of DOE Order 5400.1, General Environmental Protection Program.

6. Reviewing reports and plans that are originated by Energy Systems for DOE-ORO to ensure uniformity and consistency in meeting environmental protection program objectives. The reports and plans include ASERs, Pollution Prevention Plans, and EMPs.

\section{Line Operating Organizations}

The line operating organizations at the Y-12 Plant include those organizations with the responsibilities for accomplishing the primary missions of the Y-12 Plant, including technology services and operation of the Oak Ridge Centers for Manufacturing Technology. These organizations report to the manager of the Energy Systems Vice President for Defense and Manufacturing, as shown in Fig. 13. Within these organizations lies the primary responsibility for operating the Y-12 Plant in a manner that provides maximum protection of the environment and public, and worker safety and health by curtailing or suspending any operation that poses a clear and present danger to members of the public or to the environment. Specific responsibilities for the line organizations are described below:

1. Operate all production and plant processes in a manner that minimizes the release of toxic chemicals or other undesirable effluents to the environment.

2. Maintain, as an ongoing goal, the continual reduction of the quantities of wastes and by-products that must be disposed of, stabilized, incinerated, or otherwise treated. This must be accomplished through strict adherence to a rigorous Pollution Prevention Program.

3. Implement a dynamic Pollution Prevention Program that involves active participation of all employees. 


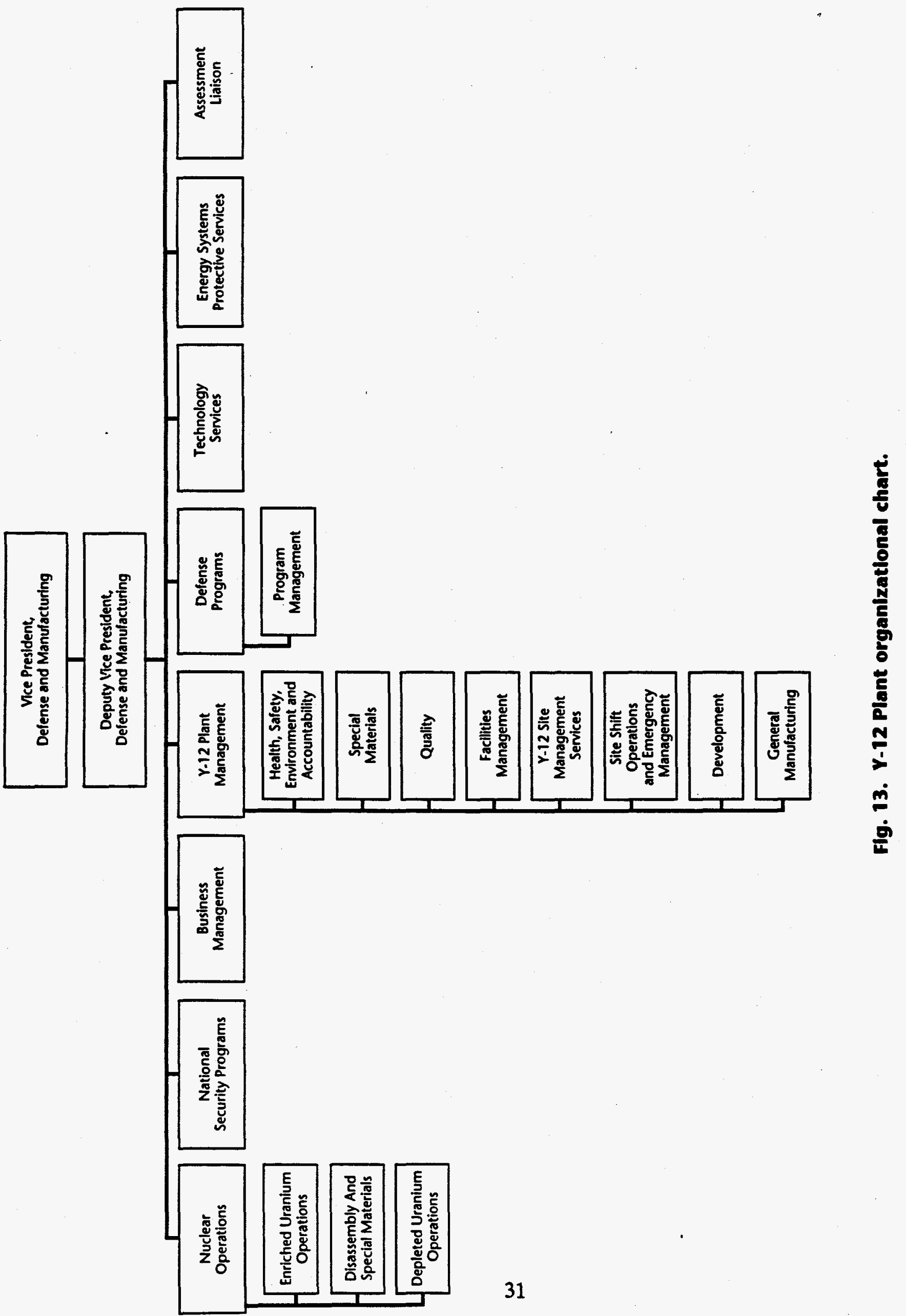


The acceptance of "ownership" of environmental responsibility is evidenced by the formation of compliance groups by organizations such as Disassembly and Special Materials, Enriched Uranium Operations, and Facility Management, to ensure that the responsibility is satisfied. In addition, each organization has an environmental officer who acts as a liaison between the operation organization and EMD.

\section{Asbestas Operation and Maintenance Program}

The presence of asbestos-containing material at $\mathrm{Y}-12$ has been well documented. These materials are found throughout $\mathrm{Y}-12$ facilities in many forms including pipe insulation, floor and ceiling tiles, and many other building materials. The solution has been to remove and dispose of the material according to EPA and Occupational Safety and Health Act (OSHA) regulations. To address these concerns, an Asbestos Operations and Maintenance Plan has been developed. This plan documents the program Y-12 has developed to manage asbestos-containing material in place.

The Y-12 Operation and Maintenance Plan is designed to comply with the myriad of asbestos-related OSHA and EPA regulations. In addition to satisfying these regulatory drivers, the Operation and Maintenance Plan addresses DOE order and Energy Systems requirements.

Finally, implementing an Operation and Maintenance Plan will help reduce any potential liabilities through the management of risk posed by asbestos-containing materials in poor condition that can release fibers into the work environment.

The Y-12 Operation and Maintenance Plan comprises a procedure that describes the principal roles and responsibilities of each individual and group accountable for operation and maintenance activities and appendices to this procedure, which address functional elements of the plan such as conducting asbestos inventories, reinspections, employee notification and training, record keeping. and program management.

Basic requirements must be satisfied at $Y-12$ to ensure that the Asbestos Operation and Maintenance Plan is successful. These requirements can be grouped into two principal categories: (1) management organization and structure and (2) technical requirements.

\section{(1) Management Organization and Structure}

Because asbestos potentially affects all occupants and workers, numerous organizations must be actively involved in the day-to-day management of the program. The Y-12 Operation and Maintenance Plan uses an expansion of the existing asbestos management organization at the facility, the formation of a management committee to formalize the accountability and planning process required for an effective program, and assignment of responsibilities on a facility level.

The procedure assigns responsibility and accountability for the program according to the existing mission for the organization tasked. Organizations providing an active role in the program include Facilities Maintenance Organization, Industrial Hygiene, Industrial Safety, Engineering, Finance, and Quality Assurance. Keys to the success of this program are that matrix responsibilities are coordinated, well understood, and within the normal framework of how work is usually conducted. 
The Asbestos Management Program Committee is the forum where changes in the policy are recommended to upper management, organizational issues are resolved, and effectiveness of the program is monitored. It is chaired by the Asbestos Program Manager and includes the other members of the Asbestos Program staff and representatives from Industrial Hygiene, QA, and others.

(2) Technical Requirements

The seven principal technical requirements addressed in the Operation and Maintenance Plan are:

- developing a comprehensive asbestos-containing material inventory,

- establishing a controls and permits system to prevent inadvertent asbestos-containing material disturbance,

- work practices,

- worker protection,

- training,

- notification, and

- record keeping.

\section{MK-Ferguson, Construction Manager}

The Construction Manager is responsible for the provision of construction management activities in support of and in compliance with government requirements and Energy Systems standards. The Construction Manager participates in preconstruction planning and is responsible for managing the construction phase of assigned projects, via services provided by using subcontractors and direct-hire personnel, ensuring quality work is accomplished on schedule and within cost with appropriate consideration being given to health, safety, and environmental requirements.

\section{Johnson Controls World Services, Incorporated (Johnson Controls)}

A- a prime contractor to DOE, Johnson Controls provides operation and maintenance of the DOE Water Plant and associated distribution piping; maintenance and repair of heavy construction equipment in support of DOE construction and MK-Ferguson; maintenance and repair of DOE MK-Ferguson light vehicles and trucks; facilities maintenance at Buildings 1916T-1/OSTI and 1916T-2; and maintenance of roads and grounds outside the fenced areas of each plant. Environmental Programs are coordinated by the Environmental Engineer through the ES\&H Manager to the Johnson Controls Project Manager. Projects requiring DOE approval or assistance are coordinated through the Contracting Officer's Technical Representative (COTR) in the ESD. The COTR, in turn, forwards such projects to the DOE Environmental Operations Branch (within ENVPD). Information flows back to Johnson Controls through the same channels. 


\section{REPORTING OF ENVIRONMENTAL RELEASES}

\section{NOOTIFICATION FOR ENVIRONMENTAL OCCURRENCES}

\subsection{General}

Notification of environmental occurrences at the Y-12 Plant follows the "Environmental Incident Reporting" operating procedure (Op 1) prepared by ENVPD. This document details the procedures that must be followed and the notifications that must be made (both inside to DOE-ORO and outside to regulatory agencies and DOE-HQ) for various environmental incident scenarios. Energy Systems Procedure OP-301, Occurrence Reporting, describes progranmatic requirements for implementation by the sites. Y-12 Plant Procedure Y60-161, Occurrence Reporting, implements these requirements. These procedures define the responsibilities and provide reporting guidance for compliance with DOE Orders 5000.3B, Occurrence Reporting and Processing of Operations Information, 5500.2B, Emergency Categories, Classes, and Notification and Reporting Requirements, 5484.1, Environmental Protection, Safety, and Health Protection Information Reporting Requirements, 5500 Series, and all applicable federal and state regulations. Also, Reports for Occurrences, which are reported to the Tennessee Emergency Management Agency (TEMA), are provided to the TDECDOE Oversight Division (DOE-O) and made available to the public through the DOE-O.

\section{Guidance on Reporting of Enforcement Actions or Notices of Violation (NOVs)}

DOE-HQ provided initial guidance on August 18, 1993, and subsequent guidance on September 16, 1993, on the subject of reporting procedures for NOVs. While requirements for reporting NOVs are presently contained in DOE Order 5000.3B, it does not sufficiently take into account the additional aspects contained in the guidance. To facilitate timely identification and reporting of environmental noncompliances by Energy Systems, the procedure ESP-EP-153, Identification and Reporting of Environmental Noncompliances, has been prepared. This procedure establishes the roles, responsibilities, and action steps that are necessary to identify, report, track, correct, validate, and verify closure of environmental noncompliance issues. The following must be addressed to properly follow the guidance issued by DOE-HQ:

1. Additional fact sheets may be necessary to supplement information missing from the Occurrence Report.

2. Copies of the NOV need to be provided along with the Occurrence Report.

3. Copies of the Occurrence Report, NOV, and any additional fact sheets need to be provided to the General Counsel; Assistant Secretary for the Environment, Safety, and Health; as well as the Associate Deputy Secretary for Field Management and the Cognizant Secretarial Officer within 24 hours of an NOV. 


\subsection{Reporting Procedures and Documentation}

The following is a general description of the procedure used to report environmental incidents and occurrences at the Y-12 Plant. (For details, please reference Procedure Y60-161, Occurrence Reporting.)

1. The individual who identifies the noncompliance immediately notifies a supervisor or the Plant Shift Superintendent (PSS). On off-shifts, the PSS is notified. The PSS, upon investigation of the occurrence, will properly classify it and determine the reportability (for example, when and to whom the incident is to be reported). The PSS, in consultation with the Facility Manager, will use Procedure Y60-161 to determine the classification and reporting requirements. If the occurrence is reportable, the PSS will notify DOE rvithin 2 hours (15 minutes, if it is an emergency) and will provide a formal notification report within 24 hours.

2. Within $\mathbf{1 0}$ days of the identification of the reportable occurrence, the responsible line management staff will issue a report of the cause, corrective actions planned, and an estimate of impacts. Following completion of corrective actions and verification of results, a final report is issued and transmitted to DOE-HQ. After approval from DOE-HQ, the occurrence report is issued to the public reading rooms listed in Appendix D. Access to controlled documents by the general public requires a formal written request to DOE-ORO.

3. If amounts of materials exceed the reportable quantities defined under CERCLASARA, off-site agencies (including federal, state, county, and city government agencies) are notified by the Y-12 PSS.

\subsection{Use of Monitoring Data to Detect Environmental Events}

Real-time monitors (the Surface Water and Hydrological Information Support System) are installed at wastewater treatment plant discharges, storm water discharge locations, and along upper East Fork Poplar Creek (EFPC). These stations provide continuous data to a control center computer that monitors the data input for unusual shifts in general water quality parameters such as $\mathrm{pH}$, temperature, and conductivity. If such unusual changes occur, an alarm will be activated, and the PSS will be notified. An investigation of the alarm will immediately follow to determine the cause of the event and whether further notifications and actions are needed.

Surface water samples are routinely collected from EFPC and from Bear Creek by EMD. These $s$ mples are analyzed and results reported to DOE and TDEC as required.

Process stacks with the potential for significant radiological airborne emissions are also equipped with breakthrough monitors, which continually monitor the emissions and provide alarms when fixed limits are exceeded, or when sudden shifts in emission quality occur. Stacks with the potential for smaller releases are sampled continuously. If analysis of these samples indicate excursions, immediate notification and response are made.

\subsection{Responsibilities}

Any member of the Y-12 Plant staff (DOE or contractor) observing or suspecting unusual environmental incidents, occurrences, or phenomena is responsible for immediately contacting the 
PSS office in accordance with Procedure Y60-161. For example, as stated in the SPCC Plan, when personnel observe a spill, they must first and immediately notify the PSS. It is stressed that only the PSS can assess the significance of a spill. All plant personnel are also responsible for developing an increasingly sharper sense of environmental awareness in the detection of unusual environmental occurrences and events through active participation in the Y-12 Plant Pollution Prevention Awareness Program.

As outlined in the SPCC, the PSS notifies the Spill Response Coordinator (SRC) of the incident. The SRC, in the EMD, collects information, evaluates the situation, and makes containment and cleanup recommendations to the PSS. The Y-12 Waste Management Organization, if requested, provides a spill response crew who will contain and collect spilled materials and perform cleanup operations.

The Y-12 PSS is responsible for properly classifying the incident and determining reportability, alerting the DOE-ORO EOC whenever a reportable event is confirmed or suspected, and providing written reports in accordance with Procedure Y60-165. In addition, the Y-12 PSS notifies appropriate federal, state, and local agencies including the National Response Center, TEMA, local emergency planning committees, and others as appropriate, as required by regulations.

The Y-12 PSS is responsible for providing 24-hour-a-day, year-round support to the Y-12 Plant staff for the notification of reportable events to DOE-HQ and DOE-ORO interfacing with the YSO or other responsible CORs, providing technical support in verifying the classification of events, and determining the necessary notifications.

\section{EFFLUENT INFORMATION SYSTEM AND ONSIIE DISCHARGE INFORMATION SYSTEM (ODIS) REPORTS}

\section{General}

The Effluent Information System and ODIS are DOE data base systems that have been developed to assist DOE-HQ and the field office staff in managing the radioactive and liquid effluents from DOE facilities. Data on effluents released off-site are entered into the Effluent Information System, and data on effluents discharged on-site and retained on-site are entered into ODIS. The data bases are compiled and maintained by the Waste Information Systems Branch, EG\&G Idaho, Inc. Unplanned releases of radioactive materials in effluents, such as spills, leaks, and so forth, whether on-site or off-site, must also be reported. Releases of no environmental concern, including those that are subsequently cleaned up, do not have to be reported. The report consists of the following:

1. A cover sheet listing site, facility, report period, contractor(s), and address;

2. A summary providing pertinent descriptive and interpretative information that will serve to explain any facets of the data that are not adequately described on the data sheets (classified effluent data must be submitted on separate forms);

3. Maps showing the locations of effluent streams and on-site discharge points; and

4. Completed DOE Form F5821.1, "Radioactive Effluent/On-Site Discharges/Unplanned Releases." 
The report is required to be submitted to EG\&G Idaho, Inc., by April 1 for the preceding calendar year.

\section{Procedure for Preparing Effluent Information System and ODIS Reports}

The Y-12 Plant EMD is responsible for preparing the information on radionuclide discharges to air and water described in Sect. 2.2.1 of this document. Radioactive effluent and on-site discharge monitoring and reporting shall be adequate to provide an annual average concentration and an annual summary of the quantities of radioactivity released. The summary should be complete to the extent that all significant releases are reported. It is necessary, therefore, that the total annual flow of each effluent stream, and the total annual number of curies of each radionuclide released via that stream be known. Also, solubility data, if known for each radionuclide, are to be reported. An individual summary report shall be prepared by the Y-12 Plant EMD, which will include total quantities and curies of enriched and depleted uranium released during the year, as well as any other information that can be submitted while the report remains unclassified."

One copy of the unclassified summary report and the Effluent Information System and ODIS data report (classified as Confidential Restricted Data) shall be submitted to the DOE-ORO YSO and ENVPD by March 10 of the year subsequent to the end of the calendar year for which the data are reported.

DOE-ORO YSO is responsible for ensuring that the Effluent Information System and ODIS data package meets the reporting requirements of DOE Order 5400.1 and that the data are complete.

Following review and assurance of data package accuracy, the DOE-ORO YSO will forward the unclassified summary report directly to computer operations at EG\&G Idaho, Inc., by April for the preceding calendar year. YSO will maintain the Effluent Information System and ODIS data forms on file and make the report available for review to individuals with the appropriate clearance.

\section{Relationship of the Effluent Information System and ODIS Report to Other Effluent Monitoringsampling and Reporting}

Data required for the Effluent Information System and ODIS report are also required for the ASER. In addition, the airborne radionuclide emission data are necessary as input for computing the off-site dose to the maximally exposed individual required by the National Emission Standards for Hazardous Air Pollutants (40 CFR Part 61, Subpart H). Therefore, ongoing radiological monitoring provides the information necessary for preparing this report.

Section $\mathbf{5 . 2}$ of this plan summarizes the effluent monitoring program that generates the required data.

${ }^{1}$ Because the Y-12 Plant Effluent Information System and ODIS report is classified as Confidential Restricted Data, DOE-HQ has waived the requirement to submit the DOE Form 5821.1 data to EG\&G Idaho, Inc. 


\section{GENERAL PLANNING AND REPORTING}

DOE Order 5400.1 requires that each facility develop general comprehensive plans that describe the objectives of environmental protection programs and that provide means, schedules, and budgets for attaining these goals. The order also requires annual reporting and interpretation of monitoring results to describe the effectiveness and progress of the environmental program in achieving desired objectives. The following discussion describes how the Y-12 Plant will prepare these general plans and reports, which include the: (1) Long-Range Environmental Protection Plan, (2) ASER, (3) OMB Circular A-106 Report, (4) ER/WM FYP, and (5) ES\&H FYP.

\subsection{LONG-RANGE ENVIRONMENTAL PROTECTION PLAN}

\subsubsection{General}

Chapter III of DOE Order 5400.1 requires that a Long-Range Environmental Protection Plan be developed for each facility. These plans will define specific environmental objectives. They also describe the means and schedules for attaining these objectives and for completing programs and projects. The ER/WM FYP and the ES\&H FYP satisfy the requirement for a Long-Range Environmental Protection Plan based on guidance from DOE-HQ (R. E Pelletier to distribution, "Clarification of the Environmental Protection Implementation Plan Guidance," October 16, 1989.)

\section{ANNUAL SITE ENVIRONMENTAL REPORT}

\section{General}

The ASER for the Y-12 Plant is prepared in conjunction with a composite report, which provides a comprehensive summary of environmental activities for DOE operations on the ORR for the calendar year. This report entitled "Oak Ridge Reservation Annual Site Environmental Report for Calendar Year" includes summaries and discussions of environmental data and key environmental management issues for the Y-12 Plant, ORNL, and K-25 Site. All Y-12 Plant input, including text and tables, is submitted to the Y-12 ASER technical coordinator for review and compilation. The Y-12 Plant input is then transmitted to the ORR ASER Project Coordinator, who is responsible for overseeing and coordinating technical editing and publication services for the ORR report. Energy Systems Environmental Compliance has oversight, guidance, and technical review responsibilities; DOE-ORO provides technical review and concurrence.

\section{Report Content}

The content and format of the ORR ASER will include, at a minimum, the information suggested in DOE Order 5400.1, Attachment II-1.

The ASER also contains an environmental compliance summary that covers a 16-month time frame (the calendar year of the ASER plus the first 4 months of the following year). Appendix $E$ provides a general outline of the report contents. 


\subsection{Data Management and Information Transfer}

The assimilation of large quantities of data and information into a single summary report can be a formidable task, unless an orderly system of data management and information transfer is in place. For the Y-12 Plant, the flow of data and information, from sample collection and monitoring, to the final report involves several steps:

1. Data collection (qualitative and quantitative);

2. Laboratory analyses;

3. Data management and storage;

4. Data analyses (e.g., dose assessments, chemical releases, and emissions);

5. Preparation of data tables, graphs, narratives, and conclusions;

6. Merging of Y-12 Plant report input into the ORR ASER (first draft);

7. Technical review and editing of the first draft (additional drafts may be necessary);

8. Incorporation of technical review comments and preparation of the final draft;

9. Technical review of the final draft; and

10. Incorporation of final comments and preparation for release of final report.

\section{Report Preparation}

The EMD Program Manager for Data Quality serves as the Y-12 Plant ASER technical coordinator and is responsible for coordination and technical review of all Y-12 Plant report input. Monitoring and compliance input for preparation of the Y-12 Plant section of the ORR ASER is provided by EMD and ER/WM. The ORNL staff provides input in support of the Y-12 Plant dose assessments and is responsible for preparing input on the following:

1. Biological sampling data;

2. Soil and sediment monitoring; and

3. External gamma radiation monitoring and ambient air at perimeter stations.

Personnel from ORNL conduct these programs for the reservation.

Completed report inputs will be transmitted to the ORR ASER Project Coordinator where the information will be merged with similar inputs for the K-25 and ORNL sites to form the first draft of the ORR ASER. Technical review of the first draft report will be conducted by DOE-ORO and Energy Systems Environmental Compliance and EMD. Technical editors will conduct a thorough review. 
Comments from the first draft review will be incorporated with assistance from the Energy Systems Environmental Management staffs at the Y-12 Plant, the K-25 Site, and ORNL. When all comments have been addressed adequately, a final draft report will be issued.

Technical reviewers of the final draft report will include all reviewers of the first draft, as well as the DOE YSO reviewers.

Technical editors will incorporate comments from the final draft review. Upon DOE approval of the final draft, editors will prepare a final report for release.

\section{Responsibilities}

The ORNL Office of Environmental Compliance and Documentation has overall responsibility for coordinating and preparing the ORR ASER. The ORR ASER report coordinator at ORNL assembles the report from input provided by the environmental technical report coordinator of each site, coordinates internal and external reviews, and has overall responsibility for document preparation.

Energy Systems Environmental Compliance serves in an oversight, guidance, and technical review role and is included in technical reviews.

The ASER coordinators at the Y-12 Plant, ORNL, and the K-25 Site are responsible for technical review and concurrence of report inputs prepared by the staff at each site. These inputs will be submitted to the ORR ASER coordinator for concurrence and technical editing.

DOE-ORO provides technical review and concurrence. ENVPD has overall DOE responsibility for technical review to ensure that the ASER is technically adequate, meets DOE Order 5400.1 requirements, and addresses all current environmental management and protection issues. The ENVPD environmental monitoring functional lead will be responsible for ensuring that all parts of the report are adequately reviewed by DOE, and that comments are submitted to the environmental report coordinator within established deadlines. The ENVPD director is. responsible for concurrence of the final report for release to DOE-HQ, to other appropriate external federal and personnel agencies, and to the general public.

\section{Schedule}

The schedule for preparation and release of the ORR ASER in the 1995 Calendar Year reporting term is detailed in Appendix F.

\section{Press Release}

Following release of the final report to DOE, appropriate federal and state agencies, and local, state, and federal government officials, a press release meeting may be scheduled by the DOE Public Information Office. Copies of the final report will be given to the local news media and interested members of the general public. The functional lead, the environmental report coordinator, and other appropriate DOE and Energy Systems staff will be available for the press conference to present a summary of the report and to answer questions. 


\subsection{OMB CIRCULAR A-106 REPORT}

Pursuant to Executive Order 12088 (E. O. 12088), all federal agencies are required to prepare an annual pollution control plan that includes estimates of costs to attain compliance with environmental requirements. One of the purposes of this process is to provide OMB with information needed to evaluate the agencies' environmental budget requests. The planning process is implemented through OMB Circular A-106, which assigns EPA the responsibility for developing guidance for agencies' A-106 plans.

The Y-12 Plant did not issue a Circular A-106 report in calendar year 1995 but incorporated all pertinent A-106 related data into the ES\&H Management Plan. This plan was issued in March 1995 as document number Y/TS-972, Revision 2. Within the ES\&H Management Plan, all environmental Activity Data Sheets (ADS) are identified as to their applicability to the A-106 plan. DOE-HQ extracted A-106 data from the ES\&H Management Plan for all DOE sites and produced a rollup report of all A-106 activities to prevent redundant reporting of environmental activities.

The next revision to the ES\&H Management Plan is expected to be issued in March 1996. Specific guidance for the contents of this version of the plan has not been received from DOE-HQ. It is expected that DOE-HQ will again extract the A-106 data from the ES\&H Management Plans and produce a single A-106 report.

\subsection{ENVIRONMENTAL RESTORATION AND WASTE MANAGEMENT FIVE-YEAR PLAN}

\subsubsection{General}

The ER/WM FYP was initiated in April 1989 at the request of then Secretary of Energy, Admiral James Watkins. The ER/WM FYP represents DOE intent to strengthen the DOE nuclear waste management activities, including environmental compliance and cleanup. The ER/WM FYP is used to coordinate and prioritize all cleanup and operations activities at DOE sites into a single, integrated plan. The purpose of the ER/WM FYP is to serve as a baseline for DOE planning, budgeting, and decision making relating to environmental cleanup, modernization, waste management, regulatory compliance, technology development activities, and proper operation of all nuclear facilities and sites.

The ER/WM FYP encompasses four major activities: corrective activities, environmental restoration, waste management, and technology development. All activities are grouped into four :riority categories. All corrective activities are defined as Priority 1 to achieve compliance on an expedited basis.

The FYP identifies seven objectives that must be achieved at Energy Systems and DOE ER/WM to accomplish their 30-year goal. These objectives are: (1) bring all DOE facilities and sites into compliance and operate them in accordance with applicable laws and regulations aimed at protecting public health and the environment; (2) treat, store, and dispose of hazardous, radioactive, and mixed waste in an environmentally sound and effective manner; (3) contain known contamination at inactive sites and vigorously assess the uncertain nature and extent of contamination at other sites to enable realistic planning, scheduling, and budgeting for cleanup; (4) develop and implement innovative, cost-effective technologies to facilitate compliance with applicable laws, regulations, and agreements and minimize the generation of waste; (5) ensure 
availability of human resources (i.e., trained scientists, engineers, and technicians) to carry out the mission; (6) continue to expand the public participation process; and (7) develop an effective management control program to ensure that public funds expended by DOE-HQ Environmental Management programs achieve maximum public health and environmental protection benefits.

\subsubsection{Plan Preparation}

EMD, ER/WM, and Technology Development provide input to the ER/WM FYP. Guidance is provided by DOE-HQ through DOE-ORO.

All data and information for the ER/WM FYP from the Y-12 Plant are submitted to the Energy Systems ER Organization FYP coordinator to be compiled and sent to DOE-ORO for review and approval (WM information is submitted through ESWMO). AMEM works with all involved organizations until all questions and comments are clarified and resolved. After resolution of questions and comments, the data information will then be transmitted to DOE-HQ by AMEM for review and concurrence.

\subsubsection{Responsibilities}

Energy Systems FYP coordinators work with Central Environmental Restoration Division, ESWMO, YSO, and DOE AMEM to ensure that information is correct. All guidance for waste management goes to Energy Systems via ESWMO.

DOE AMEM is responsible for coordinating, directing, and providing guidance to the Y-12 Plant FYP coordinators during the preparation of information for the plan. A technical and administrative review is done by DOE YSO and AMEM to ensure that the information is adequate and correct.

Planning, budgeting, and regulatory compliance for all activities in the Site-Specific Plan (SSP) are the responsibility of DOE ER/WM. Plan compliance will be ensured through reports to AMEM.

\subsubsection{Site-Specific Plan}

The SSP is used by DOE-ORO and DOE-HQ to measure progress in meeting the DOE goal for environmental cleanup, waste operations, and technology development activities. The SSP is based on the ER/WM FYP and summarizes the corrective activities, environmental restoration, waste operations, and technology development activities being conducted by each operations office staff.

DOE AMEM will have complete responsibility for activities covered in the SSP. DOE AMEM will provide the management link between DOE-HQ managers in waste management operations, environmental restoration, and research and development. DOE AMEM will be responsible to DOE-HQ for reporting on all milestones, cost accruals and compliance status, and for preparing budgets and other planning documentation.

Plans, activities, milestones, and associated schedules provided in the SSP can be used by the communities and regulators to monitor the progress of the department. The SSP is based on the information in the ADSs, which provide a basis against which technical performance, cost, and schedule will be measured. The ADSs are the basic unit of description necessary to develop a comprehensive, department-wide plan. 


\subsubsection{Activity Data Sheets}

ADSs are the central management element for the DOE Office of ER/WM planning and budget process. ADSs will be formally updated by the field with final budget information to ensure that budget and milestone information is consistent and supportive of routine preparation of the next ER/WM FYP.

The Energy Systems ER Organization manages the ADSs for ER activities such as Remedial Investigations through Remedial Actions. The WM Organization manages the ADSs pertaining to all transportation, treatment, storage, disposal, and operation activities in the waste management program at the Y-12 Plant. Other program management information, such as cost, schedule, and milestone information, is included in an Energy Systems, EMD-wide, corporate data base. Both the SSP and the ER/WM FYP are based on ADSs. ADSs are updated annually before the ER/WM FYP and SSP are due.

\subsection{ENVIRONMENT, SAFETY, AND HEALTH FIVE-YEAR PLAN}

\subsubsection{General}

The ES\&H FYP was initiated early in 1992. In response to the Secretary of Energy's request for the Safety and Health FYP of the department to "fully identify the scope of the problem, priorities, and pace of funding required to bring DOE into full compliance with all safety and health regulations," DOE Office of Environment, Safety, and Health (EH) coordinated the development of a department safety and health planning process that defined, prioritized, and allocated available resources to meet the most important safety and health activities over the planning period.

Some DOE Cognizant Secretarial Offices (CSO), including DP, elect to use the safety and health planning process and data base to produce integrated ES\&H plans that include not only the safety and health activities, but also environmental activities that are not funded by ER/WM. The ES\&H FYP encompasses three major categories of activities: core, improvement, and compliance.

\subsection{Plan Preparation}

The Y-12 Plant ES\&H planning staff, under the direction of DOE YSO, provides input to the Field Office ES\&H FYP, in the form specified in guidance documents provided by EH, DP, and YSO.

Oak Ridge Operations Office then combines information from other facilities it is responsible for and develops additional summaries. The CSO FYP follows the same format as the YSO FYP, except that the CSO reports are carried one level further and combine all the YSO reports into one composite document.

\section{Responsibilities}

The YSO is responsible for: (1) coordinating, directing, and providing requirements to the Y-12 ES\&H planning staff for the preparation of the ES\&H FYP; (2) maintaining surveillance of the FYP preparation and implementation; (3) ensuring that adequate funding is requested from 
the DOE-HQ CSO for implementation of the ES\&H FYP; and (4) releasing the final document to DOE-HQ.

The Y-12 Plant ES\&H planning staff is responsible for providing YSO with a printout of the ADSs and narrative summaries of programs and ADS functional areas.

\subsubsection{Schedule}

The ES\&H FYP is prepared annually, with Y-12 Plant staff providing input to DOE in the spring.

\section{SPECIAL PROGRAMS AND PLANS}

\subsection{GROUNDWATER PROTECTION MANAGEMENT PROGRAMS}

\subsubsection{General}

DOE Order 5400.1 states that it is DOE policy to conduct operations "in compliance with the letter and spirit of applicable environmental statutes, regulations, and standards." This policy required establishment of a groundwater protection management program by May 9, 1990. The program plan is to be reviewed annually and updated every 3 years. The order also requires groundwater monitoring staff to determine and document the effects of DOE operations on groundwater quality and quantity, development of specific groundwater monitoring plans, and an annual site environmental monitoring report, which includes a groundwater protection section.

The Y-12 Plant GWPP has been assembled to reflect the following scope:

- To define the purpose, policies, and objectives of the Y-12 Plant GWPP;

- To define the regulations, requirements, and guidance applicable to groundwater monitoring at the Y-12 Plant;

- To describe groundwater monitoring strategies used at the Y-12 Plant to meet applicable regulations and requirements;

- To evaluate hydrogeologic conditions present at the Y-12 Plant;

- To define interfaces between the GWPP and other programs; and

- To define methods, procedures, and schedules to be used in meeting GWPP objectives.

\subsection{Existing Program}

The Y-12 Plant Comprehensive Groundwater Monitoring Plan has been developed and is being implemented. This plan represents a coherent and comprehensive monitoring strategy in response to the following actions.

- In 1992, the negotiation of a Federal Facility Agreement (FFA) for the ORR was completed. 
- The ORR has been placed on the National Priorities List.

- The Exit-Pathway Monitoring Program is now part of the overall groundwater monitoring program.

- CERCLA has replaced RCRA as the lead regulatory requirement.

- RCRA is now considered to be an "applicable or relevant and appropriate requirement."

The comprehensive plan takes into account the natural systems (hydrology, topography, and geology) that control the rate of contaminant transport. In this way, the plan addresses regulatory and site-characterization objectives and ensures consistent data collection and evaluation. It also eliminates redundancy and conflict between different regulating programs whose areas of interest overlap.

In the comprehensive plan, the Y-12 Plant is divided into three sections, which are delineated by topography, surface water drainage, and patterns of groundwater flow. These sections include the Bear Creek Hydrogeologic Regime (Bear Creek regime), the Upper East Fork Poplar Creek Hydrogeologic Regime (East Fork regime), and the Chestnut Ridge Hydrogeologic Regime (Chestnut Ridge regime). The regimes are further defined according to the waste sites they contain.

\subsection{Groundwater Protection Program Management Plan}

A GWPP Management Plan, which describes each element of the current Y-12 Plant GWPP, was updated and reissued in June 1993 by Energy Systems EMD. The plan outline is as follows:

- Introduction

- Purpose and Scope of the Y-12 Plant GWPP Management Plan

- Purpose, Policies, and Objectives of the Y-12 Plant GWPP

- History of the Y-12 Plant GWPP

- Applicable Regulations, Requirements, and Guidance for Groundwater Monitoring

- RCRA requirements

- CERCLA requirements

- Monitoring requirements for nonhazardous solid waste disposal facilities

- DOE Orders

- Technical Guidance

- Y-12 Plant GWPP Monitoring Strategy

- Hydrogeologic Framework 
- Monitoring Programs and Approach

- Y-12 Plant GWPP Organization, Roles, and Responsibilities

- Organization

- Health and Safety

- Quality Assurance

- Procurement

- Engineering and Well Installation

- Sampling and Analysis

- Data Management

- Statistical Analysis, Data Validation, and Evaluation

- Record Keeping and Document Control

- Hydrogeological Interpretation

- Environmental Restoration Program

- Energy Systems Groundwater Program Office

- Project Plans

- Health and Safety Plans

- Quality Assurance Plan

- Groundwater Monitoring Well Installation Plan

- Groundwater Monitoring Plan

- Sampling and Analysis Plan

- Data Management Plan

- CERCLA Plans

- Well Plugging and Abandonment Plan

- Well Inspection and Maintenance Plan

- References 
The plan is reviewed annually and updated every 3 years.

\subsubsection{Responsibilities}

EMD is responsible for ensuring that the existing Y-12 Plant GWPP meets all the requirements of DOE Order 5400.1, reviewing the GWPP Management Plan, and continually evaluating program results to detect any degradation of groundwater quality that could potentially threaten public health.

The Y-12 Site Manager and the AMEM are responsible for providing direction and guidance from DOE-ORO to Energy Systems in the implementation of the GWPP. DOE YSO is responsible for conducting independent appraisals for the Y-12 Plant GWPP to ensure compliance with DOE Order 5400.1 and applicable regulatory requirements, and for adequacy in following the BMP.

\section{Y-12 PLANT POLLUTION PREVENTION PROGRAM}

\section{Waste Minimization}

Waste minimization activities are mandated by both statute and company policy. RCRA requires that a waste minimization plan be implemented at sites where hazardous waste is generated. DOE Order $\mathbf{5 4 0 0 . 1}$ further defines the plan contents to include an indication of management support, specific goals for reductions in waste generation, and self-auditing provisions. The Tennessee Hazardous Waste Reduction Act of $\mathbf{1 9 9 0}$ further defines waste reduction.

The Y-12 Pollution Prevention Program is an organized, comprehensive, and continuous effort to systematically reduce the volume and toxicity of all types of wastes and environmental releases from Y-12 operations. The term "pollution prevention" at Y-12 equates to the DOE definition of "waste minimization." Therefore, pollution prevention at $Y-12$ includes activities that involve multimedia source reduction and recycling of all wastes and pollutants for all media. This program applies to all solid waste, emissions, and discharges generated by site operations.

The Y-12 Pollution Prevention Program Plan has been prepared to identify pollution prevention techniques used at the Y-12 Plant and illustrates the commitment of Y-12 to reduce the generation and toxicity of wastes. The Plan satisfies all regulatory, DOE, and Energy Systems requirements for documentation of the pollution prevention program, its objectives, structure, goals, and strategies. The Plan meets all requirements for plans required by the Tennessee Hazardous Waste Reduction Act of 1990.

\section{Organization and Infrastructure}

The Pollution Prevention Program organizational structure is designed to maximize the collection, dissemination, and flow of pollution prevention information and to provide waste-generating line organizations with managerial responsibility and authority for the development, design, construction, and implementation of pollution prevention projects. 
The organizational structure of the program is the Pollution Prevention Council (Council), which includes:

- Pollution Prevention Advocates (Advocate) from each Y-12 Plant organization, including ORNL organizations located at $\mathrm{Y}-12$ and the Environmental Restoration Remedial Action Organization at Y-12;

- A full time Pollution Prevention Coordinator and Program staff; and

- Technical subject matter experts, as needed, such as the Environmental ALARA Coordinator, and staff members of the EMD.

The Council serves as an information exchange mechanism to promote general awareness of pollution prevention information, while providing a system to document pollution prevention progress and to identify resources necessary to implement pollution prevention opportunities.

Additionally, Advocates are assigned to represent and support organization managers and serve as the pollution prevention technology transfer point within their organization. This responsibility includes providing information about the wastes generated within their organization for reporting purposes, ensuring that new projects or changes to existing facilities have considered pollution prevention in design and construction, and submitting ideas or problems for pollution prevention efforts originating within their organization.

\section{Waste Generators and Employees}

All Y-12 employees generate waste and are, therefore, waste generators. Y-12 waste generators are responsible for properly managing their waste according to their training and procedural requirements to minimize the generation of waste from spills or inadvertent mixing of different waste streams. The integration of pollution prevention into the waste generator's activities is vital to the success of the program.

\section{Pollution Prevention Program Strategy, Objectives, and Goals}

\subsection{Strategy}

The strategy focuses on four major elements: (1) the evaluation of processes for pollution prevention opportunities and associated projects; (2) pollution prevention promotional activities; (3) tracking activities (including wastes and pollution prevention projects); and (4) the exchange of information and technology.

\section{Objectives}

Overall objectives of the program are to:

- Foster a plantwide philosophy to conserve resources, reduce the costs of production operations, and create a minimum of waste and pollution in achieving site-strategic objectives through developing and implementing techniques, technologies, and programs that minimize waste and pollution generation; 
- Promote the use of nonhazardous materials in Y-12 Plant operations to minimize potential risks to human health and the environment;

- Reduce or eliminate the generation of waste materials through input substitution, product reformulation, process modification, improved housekeeping, on-site closed-loop recycling, and off-site recycling to achieve minimal adverse effects on the air, water, and land when technically and economically feasible and cost effective; and

- Comply with federal and state regulations and DOE requirements for pollution prevention.

Enabling program objectives have been developed that support the overall objectives, and include promotional activities, information and technology exchange, tracking and reporting activities, waste assessments and projects, and resource allocation.

\section{Goak}

Waste generation reduction goals have been established for all of Y-12's waste categories and subcategories, as well as for reducing releases of hazardous materials to the environment and reducing hazardous materials usage. These goals are published in the Plan and represent a comprehensive evaluation of priority waste streams generated by the Y-12 Plant. Per the Tennessee Hazardous Waste Reduction Act, the Y-12 Plant also developed and established quantitative performance goals for more than $\mathbf{6 0 0}$ hazardous waste streams. The rationale for this aggressive strategy for the reduction of each waste stream is based on the site's completed pollution prevention opportunity assessments (PPOAs), scheduled pollution prevention projects, and past experience in reducing hazardous and mixed waste at Y-12. A schedule of pollution prevention and related activities is presented in the Plan. Programmatic goals have been established for reduction of release and off-site transfer of Emergency Planning and Community Right-to-Know Act, Section 313 toxic chemicals, affirmative procurement, and qualitative goals for environmental restoration and facility decontamination and decommissioning activities.

\section{Pollution Prevention Opportunity Ascessments}

The Y-12 Plant has completed PPOAs for more than 89 percent of the Y-12 Plant's waste streams. However, the mission of $\mathrm{Y}-12$ has changed, significantly impacting the areas planned for implementation of projects recommended during the PPOAs. Therefore, $Y-12$ plans to screen the recommended projects for those that are still applicable for current and future plant activities. These projects will then be prioritized using a standardized ranking criteria that has been tailored specifically to the Plant's needs.

In parallel with the screening and prioritization activities, $Y-12$ will also review current and planned Y-12 activities and determine if any areas need to be assessed or reassessed for pollution prevention opportunities. Summaries of the history and methodology associated with the PPOAs at Y-12 are included in the Plan, as well as a description of the projects completed as a result of the PPOAs and lists of projects identified during the PPOAs. The schedule for screening and prioritizing projects at $\mathrm{Y}-12$ is presented in the Plan. Information regarding pollution prevention techniques used at the Y-12 Plant, such as inventory management, operational procedures, maintenance, affirmative procurement, material substitution and process modification, recycling and reuse, and segregation practices, are also included in the Plan and in periodic progress reports published by the program. 


\subsection{Pollution Prevention Awareness}

A key component to the successful implementation of the pollution prevention philosophy has been an active Pollution Prevention Awareness Program (PPAP). The PPAP has been incorporated with the overall Pollution Prevention Program for planning purposes. The objectives of the Y-12 PPAP are to: (1) heighten awareness of general environmental activities and hazards, (2) publicize specific environmental issues, (3) train employees on their pollution prevention responsibilities, (4) recognize employees for their efforts to improve environmental conditions through pollution prevention, (5) encourage employees to participate in pollution prevention, (6) publicize success stories, and (7) involve the community in awareness activities.

The in-plant newsletter, Pollution Prevention Awareness News, now in its fifth year of publication, communicates to general plant employees specific issues regarding Y-12 environmental and pollution prevention problems, along with recycling information, general household tips on how to prevent pollution, and recognition for pollution prevention awards programs. Other methods of involving employees include larger, more concentrated efforts. Examples include the Y-12 Save Our Plan(e)t Campaign, the Recycling Program, and the Affirmative Procurement Program.

\section{ENVIRONMENTAL ALARA PROGRAM}

The DOE philosophy to maintain environmental exposures to radioactive and chemical risks at levels ALARA is an integral part of the pollution prevention program. As required by DOE orders, a formal ALARA program has been developed that complements the Pollution Prevention Program. The Y-12 Plant ALARA Plan, Y/TS-1160, was prepared in 1994. A final ALARA Plan to meet the requirements of DOE Order 5400.5 is scheduled to be issued by December 31, 1995 .

Y-12 Site ALARA Policy, Y72-003, has been established to state the objective of ensuring that the Y-12 Site will continually strive to reduce the exposure of personnel and the environment to biological, chemical, physical, or radiological hazards. This objective is to be accomplished through the analysis of collected data, establishment of ALARA goals, selection of strategy to achieve the goals, and periodic monitoring and assessment to ensure that the time and resources are being used effectively and that the goals are attainable.

\subsection{PREOPERATIONAL MONITORING OF FACILITIES, SITES, AND OPERATIONS}

\subsubsection{General}

Chapter 4, Section 3 of DOE Order 5400.1, General Environmental Protection Program, requires that a preoperational monitoring be conducted before startup of facilities, sites, and operations when there is the potential for significant adverse environmental impact. The Order further notes that where time and circumstances do not allow for completion of preoperational monitoring before startup, it shall be conducted concurrent with work on the new site, facility, or process. Where appropriate, activities and documentation conducted for NEPA compliance (DOE Order 5440.1E, National Environmental Policy Act) may substitute for compliance with this requirement.

Compliance with NEPA, as administered by the DOE NEPA Implementing Procedures (10 CFR 1021) and the Council on Environmental Quality (CEQ) regulations (40 CFR 1500-1508), ensures that consideration is given to environmental values and factors in federal planning and decision making. To strengthen its NEPA review and documentation process, DOE 
promulgated its new NEPA regulations on May 26, 1992. These new regulations expanded the list of Categorical Exclusions available for use and refined DOE's NEPA implementing procedures to more closely parallel the CEQ regulations.

\subsubsection{Implementation}

The Y-12 Plant NEPA Program maintains compliance with NEPA through the use of its Plant Procedure 70-915, NEPA Review and Compliance. In addition, internal program administration is regulated under the Administrative Procedure 50-66-EM-205, NEPA Program Administration. Operating organizations such as Facility Management, Development, and Engineering have internal procedures that define additional review and documentation steps for streamlining the internal review of projects. The DOE YSO and the DOE-ORO NEPA Compliance Officer approve of this approach and monitor this process through surveillance.

In conjunction with the NEPA review and documentation process at the Y-12 Plant, Procedure Y70-379, Construction Contractor Site Characterization and Worker Requirements (SCWR), has been established to implement a systematic and methodical process by which Y-12 Plant construction project sites and planned construction debris are characterized to determine the necessary construction worker protection requirements and to provide information to support the development of a project waste management plan. The procedure is applicable to all Y-12 Plant projects, regardless of funding source, size, or type that are managed by the Engineering Organization and that involve construction contractor or subcontractor personnel.

The practice prescribed by Procedure Y70-379 entails a three-step process. The first step, the initial SCWR review, is synchronized with the project planning phase, and is intended to provide sufficient information regarding a site to plan and budget for any extended characterization activities and special worker requirements. The second step, the final SCWR review, is a confirmation of the earlier initial SCWR work, and is intended to convey the complete set of hazard assessment and site-specific worker requirements that the construction contractor will be required to conform with during construction activities. The final SCWR documentation is prepared coincident with the completion of design work. The third step is the review and approval of the Division I construction specifications, which shows that the requirements conveyed in the final SCWR documentation have been appropriately and adequately translated into the Division I contract documentation. This step is synchronized with design completion.

\section{4-3 Responsibilities}

The process is devised to take advantage of the integration of a collection of information from a designated team of participants. SCWR team participants include representatives from, but not limited to, plant line organizations, facility and building managers, Engineering, Waste Management, and the HSEA disciplines of Environmental Management, Fire Protection, Health Physics, Health Services, Industrial Hygiene, and Industrial Safety.

The initiation of an SCWR checklist forms the basis for development of the characterization plan, evaluation of hazards, and completion of the initial SCWR report. These activities are performed jointly by the SCWR team and documented by HSEA personnel. The SCWR checklist is the primary means of requesting HSEA support services to document hazards identification for Y-12 projects involving construction activity. It is developed by an integrated multi-organizational team using historical knowledge, analytical testing, data interpretation, site visitation, interviews, or 
subject matter expertise. Engineering, in concert with the project customer and facility management team, initiates the SCWR checklist.

The initial SCWR report communicates identified hazards and any known site-specific worker protection requirements necessary to comply with site-specific policies and regulations. This report forms the basis for project planning and budgeting for HSEA concerns as it relates to site characterization and construction worker requirements, and is developed by the HSEA Organization.

During the project design phase, a review of the initial SCWR checklist is performed to verify that previously identified hazards remain applicable and that any new hazards are identified. The final SCWR checklist and Industrial Hygiene detailed checklist form the basis for the final set of hazards identification. This review is performed by the characterization team.

The final SCWR report shall communicate all identified bazards and required worker protection requirements necessary to comply with site-specific policies and regulations. This report forms the basis for detailed project design and development of Division I construction specifications and is developed by the HSEA Organization.

The Division I construction specifications are developed by the Engineering Organization and transmitted to the HSEA Organization for review and approval.

\section{ORR SITE TREATMENT PLAN (STP) TO COMPLY WITH THE FEDERAL FACILTIES COMPLIANCE ACT}

\subsection{The Federal Facilities Compliance Act}

The Federal Facilities Compliance Act was signed on October 6, 1992, to bring federal facilities (including those under the DOE) into full compliance with RCRA. The act ensures that opportunities exist for the public to be informed of waste-treatment options, and it encourages active public participation in the decisions affecting federal facilities. In addition, the act requires that DOE facilities provide comprehensive data to EPA on mixed waste inventories, treatment capacities, and treatment plans for each site. The DOE-ORO has the lead role in working with the regulatory agencies and the local public in developing STPs.

\section{5 .2 ORR STP}

The final STP for the ORR was delivered to the state of Tennessee in the Spring of 1995 and approved by TDEC in October 1995. TDEC has issued a Commissioner's Order requiring implementation of the ORR STP for mixed waste. The plan calls for mixed low-level waste on the ORR to be treated through a combination of existing/modified on-site facilities, commercial capabilities, and new on-site capabilities. Once treatment is available for mixed waste as it is generated, the ORR will be in compliance with the storage prohibition under the RCRA Land Disposal Restrictions (LDRs).

In additional to fulfilling the requirements of the Federal Facilities Compliance Act and establishing an enforceable framework in which DOE will develop methods to treat all mixed waste subject to RCRA LDR, the STP allows for storage of current and projected LDR wastes at the ORR pending the development of treatment technologies and disposal technologies. In addition, the STP fulfills a requirement of the June 1992 Federal Facilities Compliance 
Agreement into which DOE entered with EPA Region IV. One of the key provisions of this Compliance Agreement was that DOE would prepare a treatment methods plan for all mixed waste on the ORR. In lieu of the treatment methods plan, this STP is being provided to EPA.

\subsubsection{Milestones and Schedules}

The STP provides overall schedules along with milestones and target dates for achieving compliance with the LDR and a general framework for the establishment and review of milestones and target dates, the conversion of target dates into milestones, and other provisions for implementing the STP that are enforceable under the Commissioner's Order.

\subsubsection{Responsibilities}

The Integrated Mixed Waste Program under the direction of ESWMO is developing a management and reporting structure to ensure that milestones are completed in a timely and thorough manner.

\section{ENVIRONMENTAL MONITORING PROGRAMS}

\subsection{ENVIRONMENTAL MONITORING PLAN}

DOE Order 5400.1 requires that a written EMP be prepared for each site, facility, or process that uses, generates, releases, or manages significant amounts of pollutants or hazardous materials. The preparation and annual review of the EMP is coordinated by Energy Systems Energy Systems Environmental Compliance staff and addresses environmental monitoring for the ORR. As such. Y-12 Plant monitoring is addressed in this document.

\subsubsection{Plan Content}

The Y-12 Plant EMP is included in a document entitled "Environmental Monitoring Plan for the Oak Ridge Reservation." The plan includes each element of the environmental monitoring program conducted at the Y-12 Plant, K-25 Site, ORNL, and ORR as a whole. Effluent monitoring and environmental surveillance areas are included. The EMP addresses the rationale and design criteria for the monitoring program, location of monitoring stations, frequency of monitoring and measurements, procedures for field monitoring, procedures for laboratory analyses, QA requirements for lab and field, specific program implementation procedures, and direction for the preparation and disposition of reports. This information is provided for each type of monitoring conducted by or for the Y-12 Plant. On September 16, 1992, the document entitled, "Environmental Monitoring Plan for the Oak Ridge Reservation," (DOE/OR-1066), was approved by the manager of DOE-ORO. An abbreviated copy of the table of contents is shown in Appendix G. The document has been revised, updated, and issued as a controlled document in May 1995.

Some monitoring conducted on the Y-12 Site and perimeter is performed as a part of programs that cover the entire ORR and surrounding environs. This monitoring includes vegetation and off-site soil sampling, off-site aquatic and terrestrial biological monitoring, stream sediment monitoring, external gamma radiation sampling, off-site ambient air monitoring, and special studies. These monitoring activities are generally conducted by ORNL personnel and are addressed in the EMP. ORNL must update sections for which ORNL personnel are responsible with review and concurrence by $Y-12$ and K-25 staff. 
The EMP uses, to the extent possible, procedural documents already in existence or under preparation. For instance, methods for field sampling will be referenced to detailed procedure manuals that exist or are being prepared for surface water, groundwater, and air sampling. Similarly, methods for laboratory analyses will be referenced to specific method documents (e.g., EPA and American Society for Testing and Materials), and Y-12 Plant Laboratory procedure manuals.

All reference documents are checked to ensure that they are in compliance with federal, state, and local regulatory requirements.

\subsection{Plan Preparation}

Energy Systems Environmental Compliance coordinated the EMP preparation with personnel at all three Energy Systems-managed installations on the ORR. Energy Systems Environmental Compliance coordinated final document preparation by using comments of personnel from DOE-ORO, TDEC, and DOE Oversight Division (TDEC/DOE-O).

\subsection{Responsibilities}

Energy Systems Environmental Compliance had overall responsibility for preparation of the EMP. Implementation of the EMP is the responsibility of each respective site. The ORNL Environmental Surveillance Section, under the ORNL Office of Environmental Compliance and Documentation, has responsibility for the ORR Environmental Surveillance activities. The EMP must be reviewed annually and updated every 3 years to meet the requirements of DOE Order 5400.1, General Environmental Protection Program.

The Y-12 Plant EMD program manager for Data Quality is responsible for coordinating annual reviews and updates of the EMP for those areas pertaining to the Y-12 Plant. The EMD program manager is also responsible for assisting in identifying budget requirements for accomplishing needed monitoring program changes.

DOE YSO is responsible for directing and administering the requirements of DOE Order 5400.1, General Environmental Protection Program. The YSO COR will interface directly with the DP CSOs to obtain the necessary funding for preparation of the EMP and for EMP implementation.

Energy Systems Environmental Compliance is responsible for the technical adequacy of the EMP for Energy Systems. DOE-ORO ENVPD assumes a similar role for DOE.

\subsubsection{Schedule}

The EMP containing all monitoring program changes necessary to comply with DOE Order 5400.1 was approved by the manager, DOE-ORO, on May 1995.

The EMP will be reviewed annually and updated every 3 years or when significant program changes dictate.

\section{ENVIRONMENTAL MONITORING ACTIVITIES}

DOE Order 5400.1 requires an environmental monitoring program consisting of effluent monitoring and environmental surveillance. Effluent monitoring includes all monitoring of air and 
water releases to the environment (e.g., surface water discharges, groundwater, and stack emissions). Environmental surveillance includes monitoring conducted to determine the effects, if any, of DOE activities in the ambient environment (e.g., ambient stream and air monitoring, vegetation and soil sampling, groundwater, external gamma radiation monitoring, and biological and terrestrial monitoring). The following discussion details how the Environmental Monitoring Program at the Y-12 Plant is implemented and who is responsible for implementing each monitoring activity.

\section{Program Implementation}

\section{Responsibilities}

Environmental monitoring at the Y-12 Plant is the responsibility of EMD of the HSEA Organization. The EMD manager has overall responsibility for implementing a monitoring program consistent with DOE Order 5400.1, including sample collection, data management, and data reporting. An organizational chart of $\mathrm{EMD}$ has been presented previously as Figure 8 .

Energy Systems Environmental Compliance is responsible for internal oversight of monitoring activities at the Y-12 Plant to ensure that all activities are consistent with DOE Orders 5400.1 and 5400.5. The Energy Systems Environmental Compliance Environmental Protection Program coordinator will serve as the point of contact for EMD and DOE-ORO ENVPD on issues relating to monitoring program changes needed to conform with DOE orders. Energy Systems Environmental Compliance will also coordinate the production and release of monitoring plans and reports required by DOE Order 5400.1 (see Sects. 3 and 4).

DOE YSO is responsible for directing and administering all actions needed to bring the Y-12 Plant Environmental Monitoring Program into compliance with DOE Order 5400.1 and for maintaining the integrity of the program thereafter. The Y-12 COR will interface directly with DOE-ORO ENVPD to ensure that the environmental monitoring program adequately addresses all order requirements, and with DP CSOs to obtain the needed funding for the program and any required upgrades.

The DOE-ORO ENVPD director has overall responsibility for technical support and oversight of the Y-12 Plant Environmental Monitoring Program as directed by the YSO. Acting under the authority of the director, the ENVPD environmental monitoring functional lead will serve as the point of contact for Energy Systems Environmental Compliance, and YSO COR on issues relating to environmental monitoring. The ENVPD environmental monitoring functional lead will also interface with ENVPD leads for other functional areas (e.g., Clean Water Act, CAA, and Quality Assurance/Quality Control) and state and federal regulators, as necessary, to address environmental monitoring concerns.

\section{Field Monitoring and Sampling}

Most on-site monitoring at the Y-12 Plant is conducted internally by EMD, Compliance Monitoring Section. This monitoring includes:

1. NPDES effluent and surface water sampling,

2. air emissions monitoring, 
3. ambient air monitoring,

4. soil sampling in support of engineering and remedial action activities, and

5. Westbay multiport groundwater well monitoring in support of remedial action activities (by January 1994).

Some on-site Y-12 monitoring, under the direction of Y-12 staff, is also conducted under subcontract or by other Energy Systems organization personnel. Groundwater sampling is conducted by the K-25 Site Analytical Services Organization. Aquatic biological monitoring, such as that required by the Y-12 Plant Biological Monitoring and Abatement Program (BMAP) is conducted by the ORNL Environmental Sciences Division. Environmental surveillance conducted on the Y-12 Plant perimeter and nearby environs include:

1. vegetation and off-site soil sampling,

2. stream sediment sampling,

3. aquatic and terrestrial biota monitoring,

4. milk sampling,

5. ambient air monitoring, and

6. external gamma radiation monitoring.

These sampling efforts, which are generally conducted by ORNL, are not part of the site-specific Y-12 Plant Environmental Monitoring Program and are discussed separately in the EMP for the ORR.

Monitoring procedures used by the various monitoring organizations follow those specified in the ORR EMP (see Sect. 5.1). These include general procedure documents, such as the Energy Systems Environmental Surveillance Procedures Quality Control Program Manual, and site-specific implementation procedures, such as those in the Y-12 Plant NPDES Procedures. Procedures employed must meet all federal, state, and local regulatory requirements for the specific type of monitoring conducted.

\section{Laboratory Anabyses}

Coordination of laboratory analyses for the Y-12 Plant Environmental Monitoring Program is the responsibility of the Compliance Monitoring Section. Analyses conform to the specific procedural documents listed in the EMPs (or as specififed by permits and regulations) and are carried out by laboratories that have quality assurance/quality control plans consistent with the Data Quality Objectives required by program elements.

\section{Quality Assurance}

Field monitoring and laboratory analyses conform to the Quality Assurance Program as described in Chapter 9 of the EMP. 


\section{Data Rejorting}

Environmental data, reports, and documents required for regulatory compliance (such as permit applications) are prepared by EMD. The information is sent to the Y-12 Plant manager for review and concurrence, then submitted to the DOE-ORO, which submits the report to regulatory agencies. The RCRA-related reports are submitted directly to TDEC, with copies to DOE.

\section{Envinonmental Monitoring Management Information System (EMMIS)}

The EMMIS is a large repository for all environmental monitoring data gathered by EMD. This system stores the data, checks data against regulatory and best management limits, and produces various reports. A revised Stack Air Emissions subsystem of this data base has been developed and implementation is in progress. Planning for the groundwater subsystem has been initiated, and the surface water subsystem is being implemented in phases.

Phase I of the surface water subsection contains reference data, such as monitoring information and various program and project information, and was implemented in 1992.

Phase II of the surface water subsection, which was developed and brought into production in 1993, contains all information about monitoring events, generates sample bottle labels, and transmits sample information to the analytical laboratory through their Environmental Laboratory Information Management System (ELIMS). Phase III was completed in 1995 and facilitates receipt of data from the laboratory by directly linking to ELIMS, merge it with the field sampling data, and compare these results with regulatory and best management limits.

\section{Environmental Program Management Plan}

Energy Systems Environmental Compliance maintains a data base for each of the five DOE facilities managed by Energy Systems. This data base system, Environmental Program Management Plan, provides managers and their staff with a complete, concise description of each of the major environmental projects and studies at the various facilities. The data sheets contain a project description, scope, justification, and the funding summary. The data sheets also provide information on scheduled completion dates, affected environmental media, the applicable environmental program category, and any statutory requirement being fulfilled by the project. The data base is updated periodically to ensure that any changes in the project description or funding is reflected in the data base.

\section{Oak Ridge Envinonmental Information System (OREIS)}

OREIS is necessary to fulfill requirements prescribed in both the FFA and TOA and support data management activities for all five facilities managed by Energy Systems. The FFA, a tripartite agreement between DOE, EPA Region IV, and the state of Tennessee, requires DOE to maintain one consolidated data base for environmental data generated at DOE facilities on the ORR. According to the FFA, the consolidated data base is to include data generated pursuant to the FFA and data generated under federal and state environmental permits. The TOA further defines DOE staff obligations to develop a quality assured, consolidated data base of monitoring information that will be shared on a near real-time basis with the state staff by way of electronic processing. 
The OREIS is the primary component of the data management program for the Environmental Restoration Program, providing consolidated, consistent, and well documented environmental data and data products to support planning, decision making, and reporting activities. Environmental restoration data are submitted to OREIS in conjunction with regulatory reports. The Surface Water subsystem of EMMIS will be used for the pilot project for transferring environmental compliance monitoring data to OREIS.

\section{QUAITY ASSURANCE AND DATA VERIFICATION}

The quality and validity of environmental monitoring and surveillance data, and hence its usefulness, depends on a strict quality assurance and data validation program. DOE Order 5400.1, Chapter IV, Section 10, requires the implementation of a Quality Assurance/Quality Control (QA/OC) program that meets all requirements of DOE Order 5700.6C and American National Standards Institute/American Society of Mechanical Engineers NQA-1. The existing QAVQC program for the Y-12 Site either meets these requirements or is in the process of being upgraded to meet them. The following sections briefly describe the existing program and actions being taken to upgrade the quality assurance/quality control effort.

\section{QUALITY ASSURANCE PROGRAM}

\subsubsection{General}

The "Y-12 Environmental Management Department Program Quality Assurance Plan," Y-89-HSE-7000 is the quality assurance plan for overall EMD operations at the Y-12 Plant. This plan is supplemented by two important references relative to the Y-12 Plant Environmental Protection Program: (1) the field monitoring QAVC program, and (2) the analytical laboratory QAVC program. While many of the elements of each are unique to the individual program, they are interrelated through chain-of-custody procedures and sample container quality control checks. A brief description of these programs follows.

\subsection{Organizational Responsibilities}

The Y-12 Plant EMD manager is responsible for ensuring that adequate resources are allocated to provide quality data for all aspects of the program. A senior technical staff member has been appointed as program manager for environmental data quality and works with the section managers in the development of Quality Assurance Project Plans that address monitoring activities. Section managers are responsible for ensuring that all subcontract organizations have an approved QAVC program, and for responding to the concerns of independent internal and external quality assurance/quality control oversight and technical support organizations.

The Energy Systems Analytical Services Organization is responsible for auditing and approving subcontract laboratories that provide analytical services to support monitoring, surveillance, or remedial projects. The Energy Systems Y-12 Plant Quality Organization has internal oversight responsibility for environmental monitoring data produced by the Y-12 Plant.

YSO has overall responsibility for directing and administering the Y-12 Plant QA Program to ensure it meets the requirements of DOE Order 5400.1, requesting special program audits when necessary, obtaining responses to DOE-ORO and HQ audits and inquiries, and interfacing directly with DOE-ORO. 


\subsection{Field Monitoring Quality Assurance}

General EMD, Compliance Monitoring Services section, is the principal field data collection group supporting the Y-12 Plant Environmental Monitoring Program. Other data collection groups include the K-25 Site environmental sampling and support group (which provides the routine groundwater sampling services at Y-12) and the ORNL Environmental Sciences Division, which conducts on-site biological monitoring work and support for the ambient air mercury monitoring for Y-12. The following discussion summarizes the Y-12 components of the QA program; summaries of the ORNL and K-25 Site programs will be provided in the individual EPPIPs for these facilities.

Program Design A revised Quality Program Plan has been approved for the 1995 update of the ORR EMP. The Quality Program Plan is in compliance with DOE Order 5700.6C, Quality Assurance; American Society of Mechanical Engineers, Quality Assurance Program Requirements for Nuclear Facilities (NQA-1), and guidance listed in DOE Order 5400.1 and the Regulatory Gujde. In addition, this program is developed with Energy Systems quality assurance requirements and is compatible with quality assurance documents that have been prepared or are being prepared at the K-25 Site, Y-12 Plant, and ORNL.

This Quality Program Plan merges the requirements of NQA-1 with those of the EPA guidance established in "Interim Guidelines and Specifications for Preparing Quality Assurance Project Plans" (EPA/4-83-004, QAMS-005/80) and provides for their implementation. Table 1 shows the relationship between this Quality Program Plan, DOE Order 5700.6C, NQA-1, and QAMS-005/80. The numbers in the first column of Table 1 designate the sections of the proposed Quality Program chapter where the applicable NQA-1 or QAMS-005/80 element requirements are delineated.

Procedures. Procedures for field sampling are either in place or are being developed. Field procedures are of two types: (1) general quality control procedures, which describe sampling techniques, equipment decontamination, field analyses, instrument calibration, sample preservation and packaging, and chain-of-custody; and (2) specific implementation procedures that describe the step-by-step methods for field monitoring at each Y-12 Plant sampling location. Procedures of the first type are contained in a document entitled "Environmental Surveillance Procedures Quality Control Program (ESPQCP) Manual" (ES/ESH/INT-14). A multiplant committee has been chartered and tasked with the oversight of this program. Membership in the oversight committee includes personnel from: DOE-ORO, Energy Systems Environmental Compliance, Energy Systems ER, Energy Systems Central Waste Management; site representatives from K-25, ORNL, Paducah, Portsmouth, and the Y-12 Plant, ORNL Information Services Support, and the Energy Systems Analytical Project Office.

Specific implementation procedures for the Y-12 program are completed for the NPDES surface water, groundwater sampling programs, and the air program. Program modifications to address new permits, remedial investigations, and new technologies require that field procedures be periodically reviewed for adequacy and are updated as needed. 
Table 1. Relationships among the Environmental Monitoring Plan, Quality Program Plan, DOE Order 5700.6C, NQA-1, and QAMS 005/80

\begin{tabular}{|c|c|c|c|}
\hline $\begin{array}{l}\text { Bnvironmental } \\
\text { Monitoring Plan } \\
\text { Ouality Program Plan } \\
\text { Soction }\end{array}$ & $\begin{array}{l}\text { Department of Energs } \\
\text { Order } 5700.6 \mathrm{C}\end{array}$ & $\begin{array}{l}\text { National Quality } \\
\text { Aceurance-1 Element }\end{array}$ & $\begin{array}{l}\text { Quality Assuranoc Management } \\
\text { Staft-005/30 Element }\end{array}$ \\
\hline $\begin{array}{l}9.1 \\
9.1 .3 \\
9.1 .1 \\
9.1 .5\end{array}$ & 1. Program & $\begin{array}{l}\text { 1. Organization } \\
2 . \quad \text { Program }\end{array}$ & $\begin{array}{l}\text { 5.4 Project organization and } \\
\text { responsibilities } \\
\text { 5.3 Project description } \\
\text { 5.16 Quality Assurance reports } \\
\text { to management }\end{array}$ \\
\hline 9.2 & $\begin{array}{l}\text { 2. Personnel } \\
\text { Training and } \\
\text { Qualification }\end{array}$ & 2. Program & \\
\hline $\begin{array}{l}9.3 \\
9.3 .1 .1 \\
9.3 .2 \\
9.3 .3\end{array}$ & $\begin{array}{l}\text { 3. Quality } \\
\text { Improvement }\end{array}$ & $\begin{array}{l}\text { 15. Control of } \\
\text { 16. Conconforming items } \\
\text { 16.tions }\end{array}$ & $\begin{array}{l}\text { 5.1.1 } \\
\text { Internal Quality Control } \\
\text { Checks and Frequency }\end{array}$ \\
\hline $\begin{array}{l}9.4 \\
9.4 .1\end{array}$ & $\begin{array}{l}\text { 4. Documents and } \\
\text { Records }\end{array}$ & $\begin{array}{l}\text { 6. Document control } \\
\text { 17. } \\
\text { Quality assurance } \\
\text { records }\end{array}$ & $\begin{array}{ll}5.1 & \text { Title Page } \\
5.2 & \text { Table of Contents } \\
5.3 & \text { Project Description } \\
5.6 & \text { Sampling Procedures } \\
5.7 & \text { Sample Custody } \\
\text { 5.9 } & \text { Analytical Procedures }\end{array}$ \\
\hline $\begin{array}{l}9.5 \\
9.5 .1 \\
9.5 .2 \\
9.5 .3 \\
9.5 .4 \\
9.5 .5 \\
9.5 .6 \\
9.5 .7\end{array}$ & 5. Wort Process & $\begin{array}{l}\text { 5. Instructions, } \\
\text { procedures, and } \\
\text { drawings } \\
\text { 8. Identification and } \\
\text { 9. Control of items } \\
\text { 12. Control of process } \\
\text { and test equipment } \\
\text { 13. Handling, storage, } \\
\text { and shipping }\end{array}$ & $\begin{array}{l}\text { 5.6 Sampling Procedures } \\
\text { 5.9 Analytical Procedures } \\
\text { 5.7 Sample Custody } \\
\text { 5.10 Data Reduction, Validation. } \\
\text { and Reporting } \\
\text { 5.8 Calibration Procedures and } \\
\text { Frequency } \\
\text { 5.13 Preventive Maintenance } \\
\text { Procedures and Schedules }\end{array}$ \\
\hline $\begin{array}{l}9.6 \\
9.6 .1 \\
9.62\end{array}$ & 6. Design & 3. Design control & $\begin{array}{l}5.14 \text { Specific Routine } \\
\text { Procedures } \\
5.5 \text { Quality Assurance } \\
\text { Objectives for } \\
\text { Measurement Data }\end{array}$ \\
\hline 9.7 & 7. Procurement & $\begin{array}{l}\text { 4. Procurement } \\
\text { document control } \\
\text { 7. Control of purchased } \\
\text { items and services }\end{array}$ & \\
\hline 9.8 & $\begin{array}{l}\text { 8. Inspection and } \\
\text { Acceptance } \\
\text { Testing }\end{array}$ & $\begin{array}{ll}10 . & \text { Inspection } \\
11 . & \text { Test Control } \\
\text { 14. Inspection, testing, } & \text { and operating status }\end{array}$ & $\begin{array}{l}\text { 5.11 Internal Quality Control } \\
\text { Checks and Frequency }\end{array}$ \\
\hline 9.9 & $\begin{array}{l}\text { 9. Management } \\
\text { Assessment }\end{array}$ & $\begin{array}{l}\text { 2. Quality Assurance } \\
\text { program }\end{array}$ & $\begin{array}{l}5.12 \text { Performance and Systems } \\
\text { Audits and Frequency }\end{array}$ \\
\hline 9.10 & $\begin{array}{l}\text { 10. Independent } \\
\text { Assessment }\end{array}$ & 18. $\quad$ Audits & $\begin{array}{l}5.12 \text { Performance and Systems } \\
\text { Audits and Frequency }\end{array}$ \\
\hline
\end{tabular}


Training. Personnel are indoctrinated in the following subjects as they relate to a particular function: (1) general criteria, including applicable regulatory requirements and environmental sampling and analysis procedures relevant to their assigned activities; (2) the ORR EMP, associated Quality Program Plan, and relevant project-specific QAPPs; and (3) their specific job responsibilities and authority.

Because of changing technologies and regulatory protocols, training of field personnel is a continuing process. To ensure that qualified personnel are available for the array of sampling tasks within Energy Systems, training programs by EPA as well as private contractors bave been used to supplement internal training. Examples of topics addressed include:

- planning, preparation, and record keeping for field sampling;

- well construction and groundwater sampling;

- surface water, leachate, and sediment sampling;

- soil sampling;

- stack sampling;

- decontamination procedures; and

- health and safety considerations.

Record Keeping. Instrument calibration and servicing records are maintained in numbered logbooks and bound notebooks. A data management system for tracking and evaluating the results of field quality control samples has been developed.

Chain-of-Custody. The Chain-of-Custody is maintained from the point of sample collection to delivery at the laboratory by strict adherence to Procedure ESP-500, Manual Chain of Custody Procedures, contained in the Environmental Surveillance Procedures Quality Control Manual.

Audits and Assessments. Audits of field monitoring quality assurance/quality control are of three types: (1) independent external audits, (2) independent internal audits, and (3) surveillance. Independent external audits are conducted routinely by DOE YSO (generally once per year) and also by federal and state regulatory authorities (e.g., EPATDEC performance appraisal and compliance sampling inspections and EPATDEC RCRA groundwater audits). Independent internal audits are the responsibility of the Y-12 Energy Systems Quality Organization, Technical Evaluation Department, and Energy Systems Environmental Compliance. In addition, department internal assessments are routinely conducted by the Quality Assurance Specialist in accordance with departmental procedure Y50-66-EM-208, Environmental Management Department Self-Assessment Program.

Performance Reporting. Field quality assurance/quality control performance will be reported annually in the ORR Environmental Report. 


\subsubsection{Laboratory Analyses Quality Assurance}

General The Energy Systems Analytical Services Organization (ASO) and subcontract laboratories of the ASO are the principal laboratories conducting analyses in support of the Y-12 Plant Environmental Monitoring Program. Other laboratories conducting significant analytical lab work for the Y-12 Plant include the ORNL ASO Laboratory (which conducts analyses of biological media samples) and the K-25 ASO Laboratory (which conducts groundwater analyses and some subcontract work). The following discussion provides details on the Y-12 ASO QA program. Details on the analytical QA programs at ORNL and the K-25 Site will be provided in the EPPIPs prepared for these facilities.

Program Design. The Y-12 ASO QA Program meets all requirements of ASME/ANSI NQA-1 and DOE Order 5700.6C. The Y-12 written QA Plan (QAP-Y-PC-0008) formalizes the quality assurance practices used to ensure the production of quality data. An ASO QA Plan is being revised to more adequately reflect the criteria of DOE Order 5700.6C. The Y-12 ASO QA program consists of both the QA Plan and associated QA standard operating procedures.

Analytical Quality Assurance. The quality of analytical data is maintained through analyses of spikes, blanks, and duplicates, as well as through participation in internal and external QA/OC programs. Spikes and duplicates are analyzed as specified in the Analytical Operating Procedure or in accordance with customer requirements in the Statement of Work. Laboratory control standard results are recorded on control charts and used to assess process stability and determine method precision and bias. Analytical QA is assessed externally by participation in QA programs that test the ability of the laboratory to produce acceptable results from analysis of reference samples of unknown concentration.

Procedures. The procedures used for analysis of environmental samples vary depending on matrix, regulatory requirements, expected concentration, and other considerations. Procedures follow standard reference documents (e.g., American Society for Testing and Materials, EPA, and SW-846) when possible. The Y-12 ASO has developed many site-specific analytical operating procedures with additional guidance for performing the procedures from the standard reference documents. For nonstandard types of analyses, Energy Systems has developed internal procedures. Administrative procedures for the Y-12 ASO are contained in a volume entitled Y-12 Analytical Services Organization Standard Operating Procedures. This manual contains general procedures for administration of the laboratory QA and training programs.

Training. Training is conducted routinely on subjects related to quality assurance and laboratory health and safety. This training is coordinated and documented by the Y-12 ASO Training Group. A Performance Documentation Checklist training program is conducted, whereby analysts are trained on a recurrent basis on the procedures that they use. The laboratory supervisor and ASO Training Group coordinate the training and document certification of workers. On-the-job observations of Performance Document Checklists are used to certify individual performance. Additionally, blind control results are often used as part of the certification process.

Record Keeping. The Quality Assurance and Laboratory Support Departments are responsible for data management of environmental analyses results and quality assurance data. These data are maintained on line in the Y-12 ASO main computer for 6 months, then they are archived. Also, paper copies of these data are kept on file in the laboratory for 3 years, then they are sent to permanent ASO storage. The results of some external QA programs (e.g., DOE-Environmental Measurements Laboratories QA Program for Radionuclides) are stored on a 
DOE-ORO data base. These are generally stored as published reports prepared by the organization responsible for the external program.

Chain-of-Custody. Sample integrity is protected by a system of sample management, which includes Chain-of-Custody consistent with the requirements specified for each program. Samples are kept in locked storage rooms (with limited and controlled access) until the time of the analysis. The Chain-of-Custody is documented when transferring samples to external laboratories or internal satellite laboratories.

Audits and Self-Assessments. Surveillances of the Y-12 ASO are conducted both internally and externally. Internal self assessments are coordinated by the Y-12 ASO Self-Assessment Manager and the Procedure Review Manager under the direction of the Y-12 ASO QA Manager and in accordance with the ASO standard operating procedures for self assessments and reviews. The analytical procedures are reviewed to verify inclusion of all necessary and required information, including quality assurance and safety requirements, in the analytical operating procedure. This verification is accomplished by using a comprehensive program of planned and documented reviews. If the review indicates significant deficiencies in the procedure, then an internal procedure appraisal is performed to verify compliance with all aspects of the quality assurance Plan. The purpose of the internal review program is to review every analytical procedure at a rate of once every 5 years. Approximately 150 analytical procedures are reviewed every year. Internal procedure appraisals may also be performed in response to customer or auditor concerns about a particular analysis. In addition to the internal procedure reviews, internal self-assessments are planned, scheduled, and conducted at the Y-12 ASO to include surveillance of chemical hygiene and laboratory safety, Quality Assurance Plan implementation, standard operating procedures, emergency preparedness, and criticality safety. External audits are provided periodically by various groups and agencies. These may include audits by DOE, EPA, the state of Tennessee, Lockheed Martin Corporation, Energy Systems, and the Y-12 Energy Systems Quality Organization. The Y-12 ASO QA manager is responsible for ensuring that all audit findings are addressed and any problems that could impact the data quality are corrected.

Performance Reporting. The performance of the Y-12 ASO QA Program is summarized annually in the ORR ASER. The Environmental Restoration Analytical Services manager is responsible for ensuring that the data for this report are accurate and provided to Y-12 ASER technical coordinator on time (see Sect. 3.2).

\subsection{LABORATORY CERTIFICATION}

\section{Environmental Laboratories Used by the Y-12 Plant}

The Y-12 ASO conducts the majority of analytical work in support of Y-12 environmental compliance monitoring. Johnson Controls conducts the drinking water analyses for the Y-12 water distribution system. Also, during periods of heavy workloads, the Y-12 ASO will route samples to either the K-25 ASO Laboratory, the ORNL ASO Laboratory, or other laboratories selected by the Analytical Projects Office for analyses. The K-25 ASO Laboratory also conducts groundwater analyses for samples collected at the Y-12 Plant. Analyses of biological samples collected for. BMAP and TCMP activities are analyzed by the ORNL ASO Laboratory. Additional analytical services, to support environmental restoration activities, are subcontracted to commercial laboratories that have been audited and approved by Energy Systems. 


\section{Status of Certification}

State of Tennessee regulators require only those laboratories performing drinking water analyses and UST analyses to be certified. Certification for both programs occurs through satisfactory participation in the State of Tennessee Water Supply Laboratory Performance QC Program. This program involves analyses of quality control samples supplied routinely by EPA-Cincinnati and on-site audits by TDEC. Certification for radiological parameters in the drinking water program is also through TDEC and requires satisfactory performance in the DOE-Environmental Measurements Laboratory (EML) Las Vegas Radionuclide Control Program.

\subsection{Responsibilities}

The Environmental Monitoring and Radiochemistry Department managers at the Y-12 ASO have the overall responsibility for ensuring that the Y-12 ASO maintains certification by the state of Tennessee, and that only certified contract laboratories are used for Y-12 environmental analyses. The laboratory certification program is administered by the Y-12 ASO QA manager.

\section{DOE Laboratory Quality Assurance Program}

DOE Order 5400.1 requires that all DOE and contractor laboratories that conduct radiological analyses for environmental monitoring programs participate in the DOE interlaboratory QA Program coordinated by DOE-EML New York Under this program, DOE-EML semiannually submits samples of various environmental matrices to participating laboratories for analyses of a variety of radionuclides. The results of these analyses are forwarded to DOE-EML where they are compared with accepted values. A report listing the performance of each participating laboratory is distributed semiannually by DOE-EML. Each analytical laboratory conducting radiological analyses in support of the Y-12 Plant Environmental Protection Program (i.e., Y-12 ASO, K-25 ASO, ORNL ASO, and other laboratories contracted by the Analytical Project Office is participating in the DOE-EML interlaboratory QA Program. Responsibilities for the DOE-EML interlaboratory QA Program are identical to those for laboratory certification.

\section{INDEPENDENT DATA VERIFICATION PROGRAM}

Requirements for the independent data verification program at the Y-12 Plant have been developed by EH-1. Current guidance from EH-1 has been followed that directs that "Agreements-in-Principle" (required by a secretarial directive) between DOE and the host states be developed. DOE and the state of Tennessee have entered into an agreement, referred to as the TOA, whereby the state has site access to conduct independent monitoring and environmental oversight at the ORR. These activities are designed to ensure that the facility is in compliance with state, federal, and local laws and regulations, as well as assuring Tennessee citizens that their health, safety, and environment are being protected. Members of the TDEC/DOE-O will be involved in air and water environmental compliance, radiological monitoring, waste management, and environmental restoration. The Y-12 DOE ES\&H Branch (DP-813) is directly responsible for the coordination and implementations of this agreement as applicable to $Y-12$ and is responsible for the independent data verification program implemented under the TOA. The TOA contains provisions for the independent monitoring of selected effluents and ambient surveillance stations to verify the quality of data obtained by DOE. Independent audits, appraisals, and surveillance of DOE environmental monitoring and laboratory analytical programs are an integral component of the DOE and TDEC agreement. 
Appendix A

Key Federal Statutes, Executive Orders, and DOE Orders

DOE Oak Ridge Operations Office 


\title{
Appendix A
}

Key Federal StATUTES, EXECUTtVE ORDERS, AND DOE ORDERS

\author{
DOE OAK RIDGE OPERATIONS OFFICE
}

\section{Legislation}

- Title 42 U.S.C. \&\$ 2011, et seg., The Atomic Energy Act of 1954, as amended, which authorizes the conduct of atomic energy activities.

- Title 42 U.S.C. S\& 7101, et seg., The Department of Energy Organization Act, which establishes the statutory responsibility to ensure incorporation of national environmental protection goals in the formulation of energy programs, advance the goal of restoring, protecting, and enhancing environmental quality, and ensure public health and safety.

- Title 42, U.S.C. \$\$ 4321, et seg., The National Environmental Policy Act of 1969, as amended, which establishes a broad national environmental policy.

- Title 42 U.S.C. \$\$ 7401, et seg., The Clean Air Act, as amended, which provides requirements to protect and enhance the quality of the air resources of the nation to promote the public health and welfare.

- Title 42 U.S.C. \$\$ 6939(c), as amended by the Federal Facilities Compliance Act on October 6, 1992, to bring federal facilities (including those under the DOE) into full compliance with RCRA. The act waives the government's sovereign immunity, allowing fines and penalties to be imposed for RCRA violations at DOE facilities. In addition, the act requires that DOE facilities provide comprehensive data to EPA on mixed waste inventories, treatment capacities, and treatment plans for each site.

- Title 33 U.S.C. $\$ \$ 1252$, et seg., The Federal Water Pollution Control Act, as amended, which provides requirements to restore and maintain the chemical, physical, and biological integrity of the waters of the nation.

- Title 42 U.S.C. $\$ \$ 6901$, et seg., Solid Waste Disposal Act of 1965, as amended, which authorizes the U.S. Environmental Protection Agency (EPA) to regulate hazardous and solid wastes.

- Title 40 U.S.C. $\$ \$ 9601$, et seg., The Comprehensive Environmental Response, Compensation, and Liability Act of 1980, as amended, which requires the identification, characterization, and cleanup of inactive hazardous waste sites by responsible parties; and which imposes certain response and reporting requirements for operations from which hazardous substances have been released.

- Title 42 U.S.C. $\$ 300$ f, et seg., The Safe Drinking Water Act, as amended, which authorizes EPA to promulgate regulations under two specific programs: the first one protects the Nation's public drinking water supplies; the second one protects subsurface waters. 
- Title 16 U.S.C. $\$ 1451$, et seq., The Coastal Zone Management Act of 1972, as amended, which establishes and supports national coastal zone management policies.

- Title 16 U.S.C. $\$ 1531$, et seq., The Endangered Species Act of 1973, as amended, which establishes a program for the conservation of endangered species and their ecosystems.

- Title 42 U.S.C. $\$ 662$, et seq., The Fish and Wildlife Coordination Act, as amended, which authorizes the Secretary of the Interior to provide assistance to and cooperate with public and private organizations in the development and protection of the Nation's fish and wildlife.

- Title 16 U.S.C. $\$$ 470, et seg., The National Historic Preservation Act of 1966, as amended, which establishes the policy of the U.S. Government to protect and preserve historical structures, sites, and artifacts.

- Title 15 U.S.C. $\$$ 2601, et seg., Toxic Substances Control Act, as amended, which provides requirements to safely regulate the manufacture, processing, distribution in commerce, use or disposal of chemical substances and mixtures that may present an unreasonable risk to either the public health or the environment.

- Title 42 U.S.C. \$ 1996, et seq., The American Indian Religious Freedom Act, as amended, which establishes a policy of the U.S. Government to protect and preserve for American Indians their inherent right of freedom of religion, including access to sites.

- Title 7 U.S.C. $\$ 136$, et seg., The Federal Insecticide, Fungicide, and Rodenticide Act, as amended, which authorizes the EPA to promulgate regulations governing the use and disposal of pesticides.

- Title 42 U.S.C. $\$ \$ 4901$, et seq. The Noise Control Act of 1972, as amended, which establishes a means for coordination of federal noise control research, setting noise emission standards, and providing information to the general public.

- Title 33 U.S.C. $\$ 1401$, et seg., The Marine Protection, Research, and Sanctuaries Act, as amended, which regulates the dumping of materials into ocean waters.

- Title 16 U.S.C. $\$ 1271$, et seq., The Wild and Scenic Rivers Act, as amended, which establishes a national wild and scenic rivers system to preserve and protect selected rivers of the Nation.

- Title 42 U.S.C. $\$ 10101$, et seg., The Nuclear Waste Policy Act of 1982, as amended, which provides for the development of repositories for the disposal of high-level radioactive waste and spent fuel, and establishing a program of research, development, and demonstration regarding the disposal of high-level radioactive waste and spent nuclear fuel.

- Title 42 U.S.C. $\$ 2021$, et seq., The Low-Level Radioactive Waste Policy Act, as amended, which establishes procedures for the implementation of compacts providing for the establishment and operation of regional disposal facilities for low-level radioactive waste.

- Title 42 U.S.C. $\$ 7901$, et seq., The Uranium Mill Tailings Radiation Control Act of 1978, as amended, which provides for a remedial action program at selected, inactive, uranium mill tailings sites. 
- Title 42 U.S.C. $\$ \$$ 13101, et seq., The Pollution Prevention Act of 1990, which establishes prevention or reduction of pollution at the source as a national policy, and which requires EPA to establish a source reduction program.

\section{EXECUTIVE ORDERS}

- Executive Order 1191, "Protection and Enhancement of Environmental Quality," of May 7, 1970, including its amendment, Executive Order 1191 of May 24, 1977, which requires that the federal government shall provide leadership in protecting and enhancing the quality of the environment of the nation to sustain and enrich human life.

- Executive Order 12088, "Federal Compliance with Pollution Control Standards," of October 13, 1978, which requires that all federal facilities and activities comply with applicable pollution control standards.

- Executive Order 12580, "Superfund Implementation," of January 23, 1987, which delegates to various federal officials the responsibilities vested in the President for implementing the Comprehensive Environmental Response, Compensation, and Liability Act of 1980 (CERCLA or Superfund) and the Superfund Amendments and Reauthorization Act of 1986 (SARA). [The Order delegates most of these responsibilities to the Administrator of the Environmental Protection Agency (EPA), but several responsibilities are delegated to the heads of federal agencies, including DOE.]

- Executive Order 12856, Federal Compliance with Right-to-Know Laws and Pollution Prevention Requirements, of August 1993, subjects all federal agencies to the Emergency Planning and Community Right-to-Know Act (EPCRA). EPCRA, also referred to as SARA Title III, requires reporting of chemical inventories and environmental releases to federal, state, and local authorities. EPCRA was not directly applicable to federal agencies until this Executive Order.

- Office of Management and Budget (OMB) Circular No. A-106, "Reporting Requirements in Connection with the Prevention, Control, and Abatement of Environmental Pollution of Existing Federal Facilities," of December 31, 1974.

\section{DOE Orders}

- DOE Order 5000.3B: Occurrence Reporting and Processing of Operations Information, Change 1: The purpose of this order establishes a DOE system for identification, categorization, notification, analysis, reporting, followup, and closeout of occurrence.

- DOE Order 5400.1: General Environmental Protection Program: The purpose of this order is to establish environmental protection program requirements, authorities, and responsibilities for DOE operations for ensuring compliance with applicable federal, state, and local environmental protection laws and regulations, executive orders, and internal department policies. The order more specifically defines environmental protection requirements that are generally established in DOE 5480.1B.

- DOE Order 5400.2B: Environmental Compliance Issue Coordination, Change 1: The purpose of this order is to set forth policy, direction, and procedures for coordinating environmental issues that are of significance to DOE. 
- DOE Order 5400.4: Comprehensive Environmental Response, Compensation and Liability Act Requirements: The purpose of this order is to establish and implement DOE CERCLA policies and procedures as prescribed by the National Oil and Hazardous Substances Pollution Contingency Plan and under the authorities of Executive Order 12580 within the framework of the environmental programs established under DOE 5400.1.

- DOE Order 5400.5: Radiation Protection of the Public and the Environment: The purpose of this order is to establish standards and requirements for operations of DOE and DOE contractors with respect to protection of members of the public and the environment against undue risk from radiation.

- DOE Order 5440.1E: National Environmental Policy Act: This order establishes DOE responsibilities and procedures to implement NEPA.

- DOE Order 5480.1B: Environment, Safety, and Health Program for DOE Operations, Change 5: The purpose of this order is to outline environmental protection, safety, and health protection policies and responsibilities.

- DOE Order 5480.4: Environmental Protection, Safery, and Health Protection Standards, Change 4: The purpose of this order is to specify and provide requirements for the application of the mandatory ES\&H standards applicable to all DOE and DOE contractor operations, to provide a listing of reference ES\&H standards, and to identify the sources of the mandatory and reference ES\&H standards.

- DOE Order 5482.1D: Environment, Safety, and Health Appraisal Program, Change 1: The purpose of this order is to establish the DOE environmental protection, safety, and health protection appraisal program.

- DOE Order 5484.1: Environmental Protection, Safety, and Health Protection Information Reporting Requirements, Change 7: The purpose of this order is to establish the requirements and procedures for reporting and investigating matters of environmental protection, safety, and health protection significance to DOE operations.

- DOE Order 5500.2B: Emergency Categories, Classes, and Notification and Reporting Requirements, Change 1: The purpose of this order is to establish DOE emergency categories, classes, and notification and reporting requirements to facilitate the communication and reporting of emergency events.

- DOE Order 5700.6C: Quality Assurance: The purpose of this order is to establish quality assurance requirements for DOE. The provisions of this Order apply to the work performed by all Departmental Elements and management and operating contractors as provided by law or contract and implemented by the department's contracting officer. If conflicts between this and other Departmental Orders exist, the quality assurance requirements of DOE 5700.6C take precedent.

- DOE Order 5820.2A: Radioactive Waste Management: The purpose of this order is to establish policies, guidelines, and minimum requirements by which DOE manages radioactive, mixed waste, and contaminated facilities. 
Appendix B

Regulations Applicable or Potentially Applicable to Y-12 


\begin{tabular}{|c|c|c|c|}
\hline Regulated Category & Regulạtion & Reference & Comments \\
\hline
\end{tabular}




\begin{tabular}{|c|c|c|c|}
\hline Regulated Category & Regulation & Reference & Comments \\
\hline Water Ouality & $\begin{array}{l}\text { State } \\
\text { State regulations governing point source } \\
\text { discharges and stormwater discharges } \\
\text { under the National Pollutant Discharge } \\
\text { Elimination System Permit program } \\
\text { State } \\
\text { State regulations require prior approval } \\
\text { through a permit for any construction } \\
\text { activity in the "waters of the state" } \\
\text { Federal } \\
\text { Federal regulation governing major } \\
\text { construction activities in "navigable waters" } \\
\text { Federal } \\
\text { The Rivers and Harbors Act regulates } \\
\text { dredge and fill activities in navigable waters } \\
\text { within the U.S. }\end{array}$ & $\begin{array}{l}\text { State } \\
\text { National Pollutant Discharge Elimination System } \\
\text { Permit Regulation, TDEC Title 1200 } \\
\text { Chapter 4-10.05 } \\
\text { State } \\
\text { Aquatic Resource Alteration, TDEC 1200-4-7 } \\
\text { Pederal } \\
\text { Army Corps of Engineers Permit Program } \\
\text { Regulations, Navigation and Navigable Waters, } \\
\text { Title } 33 \text { CFR Parts } 320 \text { through 330 } \\
\text { Pederal } \\
\text { Rivers and Harbors Act } \\
\text { Discharge of Dredged or Fill Material into } \\
\text { Navigable Waters, Title } 40 \text { CFR Part 230; Army } \\
\text { Corps of Engineers Permit Program Regulations, } \\
\text { Navigation and Navigable Waters, Title 33 CFR } \\
\text { Parts } 320 \text { through 330. }\end{array}$ & $\begin{array}{l}\text { TDEC adopted the EPA rule that } \\
\text { requires an NPDES permit } \\
\text { application for any stormwater } \\
\text { discharges associated with an } \\
\text { industrial activity and all point } \\
\text { source discharges. The Y-12 Plant } \\
\text { presently operates under an existing } \\
\text { TDEC NPDES permit. A new } \\
\text { permit is being negotiated as of this } \\
\text { date. } \\
\text { For any alteration or construction in } \\
\text { "waters of the state" or navigable } \\
\text { waters, an Aquatic Resource } \\
\text { Alteration permit will be applied for } \\
\text { under TDEC Title } 1200 \text {, } \\
\text { Chapter } 47 \text {. }\end{array}$ \\
\hline
\end{tabular}




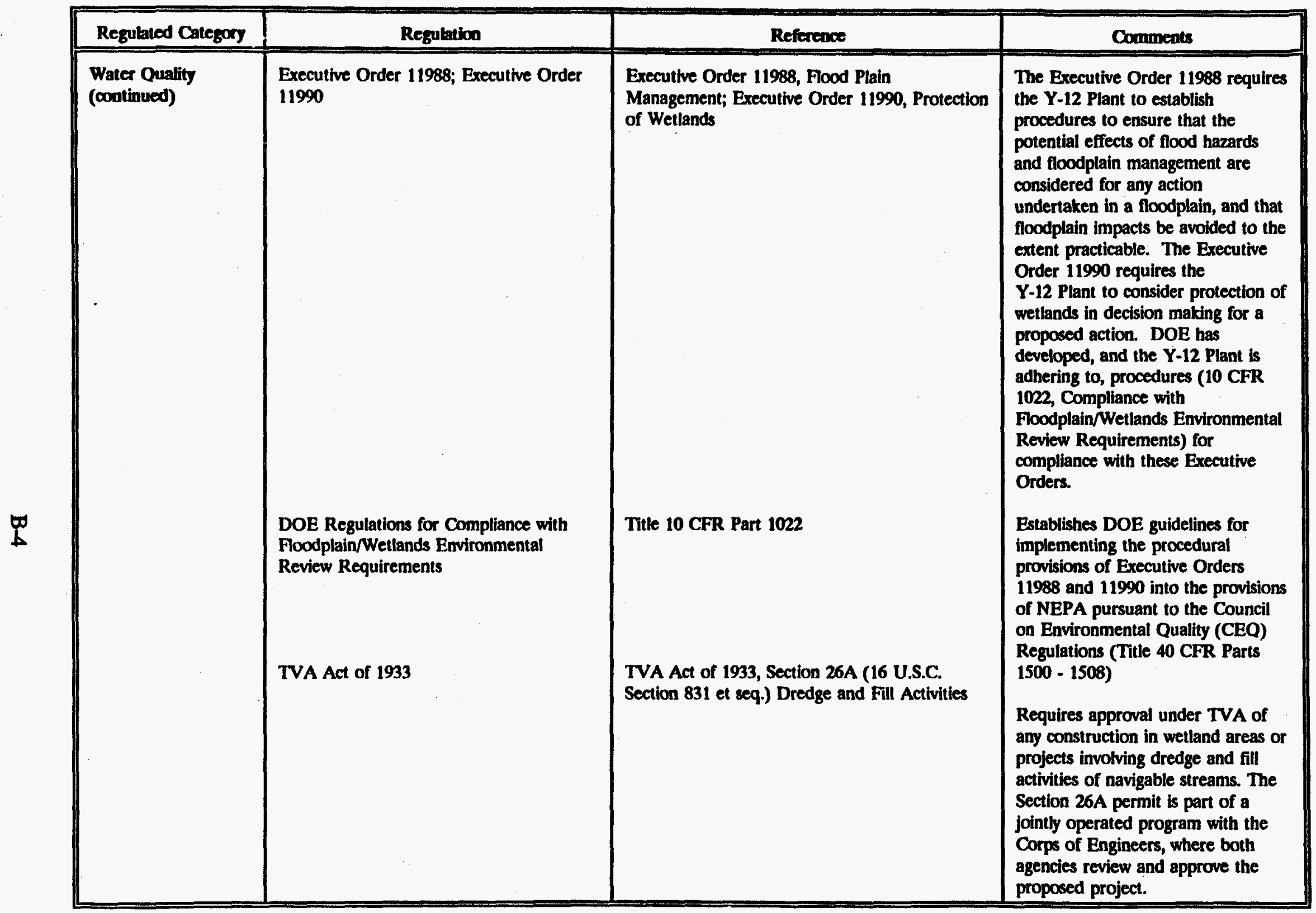




\begin{tabular}{|c|c|c|c|}
\hline Regulated Category & Regulation & Reference & Comments \\
\hline Solid Waste & $\begin{array}{l}\text { State } \\
\text { Solid Waste Management Regulations } \\
\text { (40 CFR, Part 241) }\end{array}$ & $\begin{array}{l}\text { State } \\
\text { TDEC, Regulations Governing Solid Waste } \\
\text { Processing and Disposal, TDEC Title 1200, } \\
\text { Chapter 1.7 }\end{array}$ & 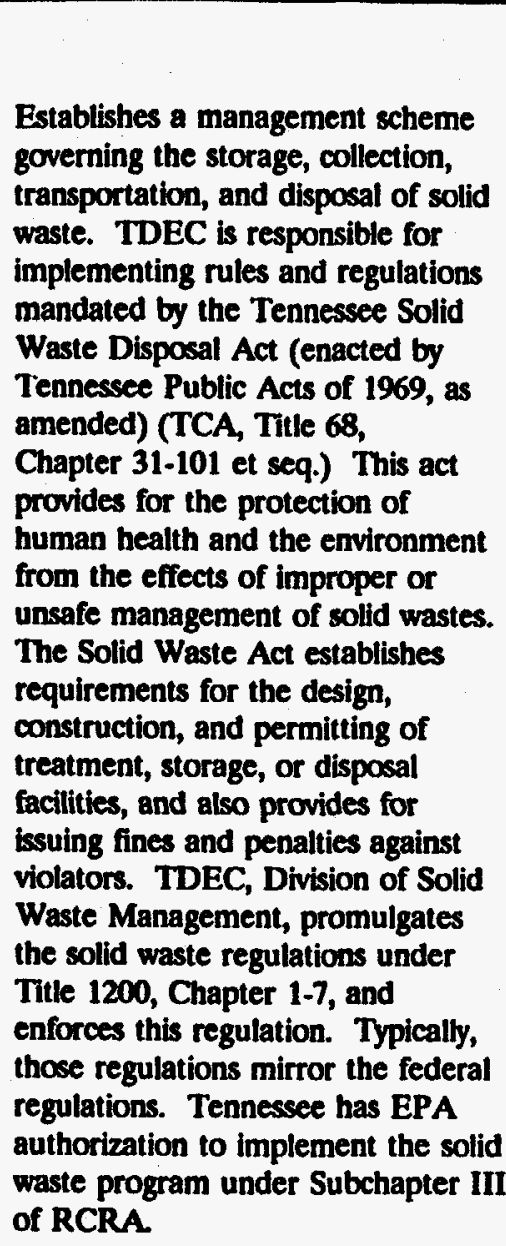 \\
\hline
\end{tabular}




\begin{tabular}{|c|c|c|c|}
\hline Regulated Caregory & Regulation & Referenoce & Comments \\
\hline $\begin{array}{l}\text { Solid Waste } \\
\text { (continued) }\end{array}$ & $\begin{array}{l}\text { Federal } \\
\text { Environmental Protection Agency } \\
\text { Guidelines for the Land Disposal of Solid } \\
\text { Wastes }\end{array}$ & $\begin{array}{l}\text { Foderal } \\
\text { Environmental Protection Agency, Guidelines for } \\
\text { the Land Disposal of Solid Wastes, Title } 40 \text { CFR } \\
\text { Part } 241 .\end{array}$ & 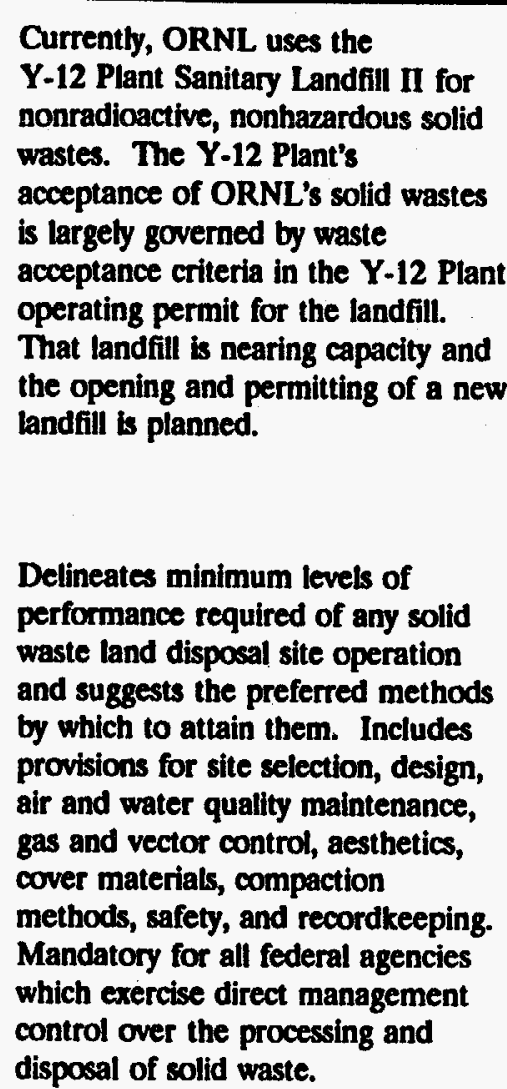 \\
\hline
\end{tabular}




\begin{tabular}{|c|c|c|c|}
\hline Regulated Category & Regulation & Reference & Comments \\
\hline
\end{tabular}




\begin{tabular}{|c|c|c|c|}
\hline Regulated Category & Regulation & Refereoce & Comments \\
\hline $\begin{array}{l}\text { Harardous Waste } \\
\text { (continued) }\end{array}$ & $\begin{array}{l}\text { Federal } \\
\text { Environmental Protection Agency } \\
\text { Regulations Identifying Hazardous Waste }\end{array}$ & $\begin{array}{l}\text { Pederat } \\
\text { Environmental Protection Agency, Identification } \\
\text { and Listing of Hazardous Waste, Title } 40 \text { CFR } \\
\text { Part } 261 \\
\text { Environmental Protection Agency, Standards } \\
\text { Applicable to Generators of Hazardous Waste, } \\
\text { Title } 40 \text { CFR Part 262; Environmental } \\
\text { Protection Agency, Standards Applicable to } \\
\text { Transporters of Hazardous Waste, Title } 40 \text { CFR } \\
\text { Part } 263 \\
\text { Environmental Protection Agency, Standards for } \\
\text { Owners and Operators of Hazardous Waste } \\
\text { Treatment, Storage, and Disposal Facilities, } \\
\text { Title } 40 \text { CFR Part } 264 \\
\text { Environmental Protection Agency, Land Disposal } \\
\text { Restrictions, Title } 40 \text { CFR Part } 268\end{array}$ & $\begin{array}{l}\text { Establishes criteria for identifying } \\
\text { characteristics of hazardous waste } \\
\text { (Subpart B). Identifies } \\
\text { characteristics of hazardous waste } \\
\text { according to ignitability, corrosivity, } \\
\text { reactivity, and EP-toxicity } \\
\text { (Subpart C). Lists solid wastes that } \\
\text { are subject to regulation as } \\
\text { hazardous wastes. } \\
\text { Establishes standards which apply to } \\
\text { transporters and generators of } \\
\text { hazardous waste. Outlines } \\
\text { procedures for compliance with the } \\
\text { manifest system and record keeping } \\
\text { requirements. Includes actions } \\
\text { required in the event of discharge of } \\
\text { hazardous waste during } \\
\text { transportation. } \\
\text { Establishes minimum national } \\
\text { standards for the management of } \\
\text { hazardous wastes. This part } \\
\text { mandates requirements for design } \\
\text { and operation of facilities that treat, } \\
\text { store and dispose of hazardous } \\
\text { waste. } \\
\text { Establishes treatment standards for } \\
\text { all hazardous wastes as specified by } \\
\text { the Hazardous and Solid Waste } \\
\text { Amendments of } 1984 \text {. Bans the } \\
\text { storage and disposal in or on the } \\
\text { land of untreated hazardous wastes. } \\
\text { Includes a provision whereby an } \\
\text { operator can receive a variance to } \\
\text { dispose untreated hazardous waste if } \\
\text { he can demonstrate that the waste } \\
\text { will not migrate from the disposal } \\
\text { unit for as long as the wastes are } \\
\text { hazardous. }\end{array}$ \\
\hline
\end{tabular}




\begin{tabular}{|c|c|c|c|}
\hline Regulated Category & Regulation & Reference & Comments \\
\hline $\begin{array}{l}\text { Hacardous Waste } \\
\text { (continued) }\end{array}$ & $\begin{array}{l}\text { Environmental Protection Agency } \\
\text { Regulations for Federally Administered } \\
\text { Hazardous Waste Permit Programs }\end{array}$ & $\begin{array}{l}\text { Environmental Protection Agency, EPA } \\
\text { Administered Permit Programs: The Hazardous } \\
\text { Waste Permit Programs, Title } 40 \text { CFR Part } 270\end{array}$ & $\begin{array}{l}\text { Establishes requirements necessary } \\
\text { to obtain and maintain permits" } \\
\text { under the hazardous waste permit } \\
\text { program of RCRA. Includes } \\
\text { application requirements } \\
\text { (Subpart B), Standards Permit } \\
\text { Conditions (Subpart C), and } \\
\text { monitoring and reporting } \\
\text { requirements (Subpart C). Applies } \\
\text { to generators, transporters and } \\
\text { treaters, storers, or disposers of } \\
\text { hazardous waste. While RCRA } \\
\text { regulations define which wastes are } \\
\text { considered hazardous wastes, the } \\
\text { Y-12 Plant must often manage } \\
\text { RCRA hazardous wastes which are } \\
\text { also contaminated with low levels of } \\
\text { radioactivity. These wastes are } \\
\text { known as "mixed wastes." DOE } \\
\text { Order 5820.2A defines mixed wastes } \\
\text { as "Waste containing both } \\
\text { radioactive and hazardous } \\
\text { components as defined by the } \\
\text { Atomic Energy Act (AEA) and the } \\
\text { Resource Conservation and } \\
\text { Recovery Act (RCRA), } \\
\text { respectively." Mixed waste } \\
\text { management practices must comply } \\
\text { with all criteria of both RCRA and } \\
\text { the AEA. }\end{array}$ \\
\hline & $\begin{array}{l}\text { Hazardous Materials Regulations } \\
\text { ( } 49 \text { CFR, Subchapter C) }\end{array}$ & $\begin{array}{l}\text { Department of Transportation Hazardous } \\
\text { Material Tables and Communications } \\
\text { Regulations, Title } 49 \text { CFR Part } 172\end{array}$ & $\begin{array}{l}\text { Lists and classifies materials which } \\
\text { the Department of Transportation } \\
\text { (DOT) has designated hazardous for } \\
\text { purposes of transportation. } \\
\text { Prescribes requirements for shipping } \\
\text { papers, package marking, labeling, } \\
\text { and placarding. Applies to } \\
\text { hazardous materials carried by air, } \\
\text { highway, rail, or water. }\end{array}$ \\
\hline
\end{tabular}




\begin{tabular}{|c|c|c|c|}
\hline Regulated Categany & Regulation & Reference & Comments \\
\hline \multirow{2}{*}{$\begin{array}{l}\text { Hapardous Waste } \\
\text { (continued) }\end{array}$} & $\begin{array}{l}\text { Hazardous Materials Regulations } \\
\text { (49 CFR, Subchapter C) }\end{array}$ & $\begin{array}{l}\text { Department of Transportation, Carriage by Rail, } \\
\text { Title } 49 \text { CFR Part } 177\end{array}$ & $\begin{array}{l}\text { Prescribes requirements (in addition } \\
\text { to those in Parts 172, 173, and 179) } \\
\text { with respect to transportation of } \\
\text { hazardous materials in or on rail } \\
\text { cars. Covers handling and loading } \\
\text { with detailed requirements for } \\
\text { radioactive, corrosive, and other } \\
\text { hazardous materials. }\end{array}$ \\
\hline & $\begin{array}{l}\text { Hazardous Materials Regulations } \\
\text { (49 CFR, Subchapter C) }\end{array}$ & $\begin{array}{l}\text { Department of Transportation, Carriage by } \\
\text { Public Highway, Title } 49 \text { CFR Part } 177\end{array}$ & $\begin{array}{l}\text { Establishes regulations and } \\
\text { procedures applicable to all private, } \\
\text { common, and contract carriers } \\
\text { transporting hazardous materials by } \\
\text { motor vehicles. Includes } \\
\text { requirements for loading and } \\
\text { unloading and accidents to vehicles } \\
\text { and shipments in transit (including } \\
\text { those carrying radioactive materials). }\end{array}$ \\
\hline
\end{tabular}




\begin{tabular}{|c|c|c|c|}
\hline Regulated Category & Regulation & Reference & Cunnments \\
\hline Radioactive Waste & $\begin{array}{l}\text { Environmental Standards for the } \\
\text { Management and Disposal of High-Level } \\
\text { Radioactive Waste }\end{array}$ & . & $\begin{array}{l}\text { Establishes generally applicable } \\
\text { environmental standards for the } \\
\text { management and disposal of spent } \\
\text { nuclear fuel, high-level radioactive } \\
\text { wastes, and transuranic radioactive } \\
\text { wastes. Applies to various waste } \\
\text { management and storage operations } \\
\text { of commercial and military nuclear } \\
\text { programs (Subpart A) and to } \\
\text { disposal of the wastes by any } \\
\text { method (Subpart B). Subpart A } \\
\text { sets levels of radiation emissions that } \\
\text { are designed to limit individual } \\
\text { exposures to the public prior to } \\
\text { disposal. Containment requirements } \\
\text { limit the total projected releases } \\
\text { over a 10,000-year period after } \\
\text { disposal. Assurance requirements } \\
\text { incorporate a system of active } \\
\text { controls and monitoring over a few- } \\
\text { hundred-years period, passive } \\
\text { controls such as permanent markers } \\
\text { and records for long-term site } \\
\text { recognition, and multiple barriers for } \\
\text { waste isolation. Long-term } \\
\text { management of radioactive waste is } \\
\text { atso guided by DOE Order } 5820.2 \mathrm{~A} \\
\text { and this regulation. }\end{array}$ \\
\hline & $\begin{array}{l}\text { Draft } 10 \text { CFR 834; Interim storage of } \\
\text { radioactive waste }\end{array}$ & DOE Order 5400.5 (Draft 10 CFR 834) & $\begin{array}{l}\text { Establishes radiation protection } \\
\text { requirements for the public and the } \\
\text { environment for Department of } \\
\text { Energy (DOE) contractor } \\
\text { operations. }\end{array}$ \\
\hline
\end{tabular}




\begin{tabular}{|c|c|c|c|}
\hline Regulated Category & Regulation & Reference & Comments \\
\hline $\begin{array}{l}\text { Minod Waste } \\
\text { (Harardous and } \\
\text { Radioactive) }\end{array}$ & $\begin{array}{l}\text { Federal Facilities Compliance Act was } \\
\text { signed on October } 6,1992 \text {, to bring federal } \\
\text { facilities (including those under DOE) into } \\
\text { full compliance with RCRA }\end{array}$ & $\begin{array}{l}\text { State of Tennessee Department of Environment } \\
\text { and Conservation, Commissioner's Order, Case } \\
\text { Number } 95-0514 \\
\text { State } \\
\text { Tennessee Code Annotated Section } 68.212-111 \\
\text { Federal } \\
\text { Title } 42 \text { U.S.C. } 56939(\text { c) }\end{array}$ & $\begin{array}{l}\text { Site treatment plans (STPs) are } \\
\text { required for facilities at which DOE } \\
\text { generates or stores mixed waste. } \\
\text { The purpose of the proposed STP is } \\
\text { to identify to the Tennessee } \\
\text { Department of Environment and } \\
\text { Conservation (TDEC) the proposed } \\
\text { options (i.e., treatment method, } \\
\text { facility, and schedule) for treating } \\
\text { mixed waste at the ORR. These } \\
\text { options include for some waste types } \\
\text { continued waste characterization, } \\
\text { development, and/or modification of } \\
\text { treatment technologies to provide } \\
\text { the needed capacity. The STP also } \\
\text { is being provided to the EPA as the } \\
\text { Appendix B treatment methods plan } \\
\text { pursuant to the requirements } \\
\text { contained in the ORR FFCA. To } \\
\text { the extent possible, the STP } \\
\text { designates specific facilities for the } \\
\text { treatment of mixed waste and } \\
\text { proposes schedules as set forth in } \\
\text { the Act. If this is not possible, the } \\
\text { STP provides schedules for } \\
\text { alternative activities such as waste } \\
\text { characterization and technology } \\
\text { assessment. TDEC approved the } \\
\text { plan and issued an implementing } \\
\text { order in October 1995. }\end{array}$ \\
\hline
\end{tabular}




\begin{tabular}{|c|c|c|c|}
\hline Regulated Category & Regulation & Reference & Comments \\
\hline Pesticides & $\begin{array}{l}\text { Federal } \\
\text { Regulation requiring all pesticides sold or } \\
\text { distributed in the United States to be } \\
\text { registered with the EPA. }\end{array}$ & $\begin{array}{l}\text { Federal } \\
\text { Federal Insecticide, Fungicide, Rodenticide Act, } \\
7 \text { U.S.C. } 136 \text { et seg; Title } 40 \text { CFR Part 156; } \\
\text { Title } 40 \text { CFR Part } 165\end{array}$ & $\begin{array}{l}\text { Established for the purpose of } \\
\text { requiring registration of pesticides to } \\
\text { protect consumers from misbranded, } \\
\text { adulterated, and/or unaffected } \\
\text { pesticides. FIFRA's primary target } \\
\text { is the pesticides/herbicide } \\
\text { manufacturing industry. However, } \\
\text { portions of the Act are applicable to } \\
\text { the Y-12 Plant procurement, } \\
\text { storage, usage, handling, and } \\
\text { disposal practices. }\end{array}$ \\
\hline
\end{tabular}




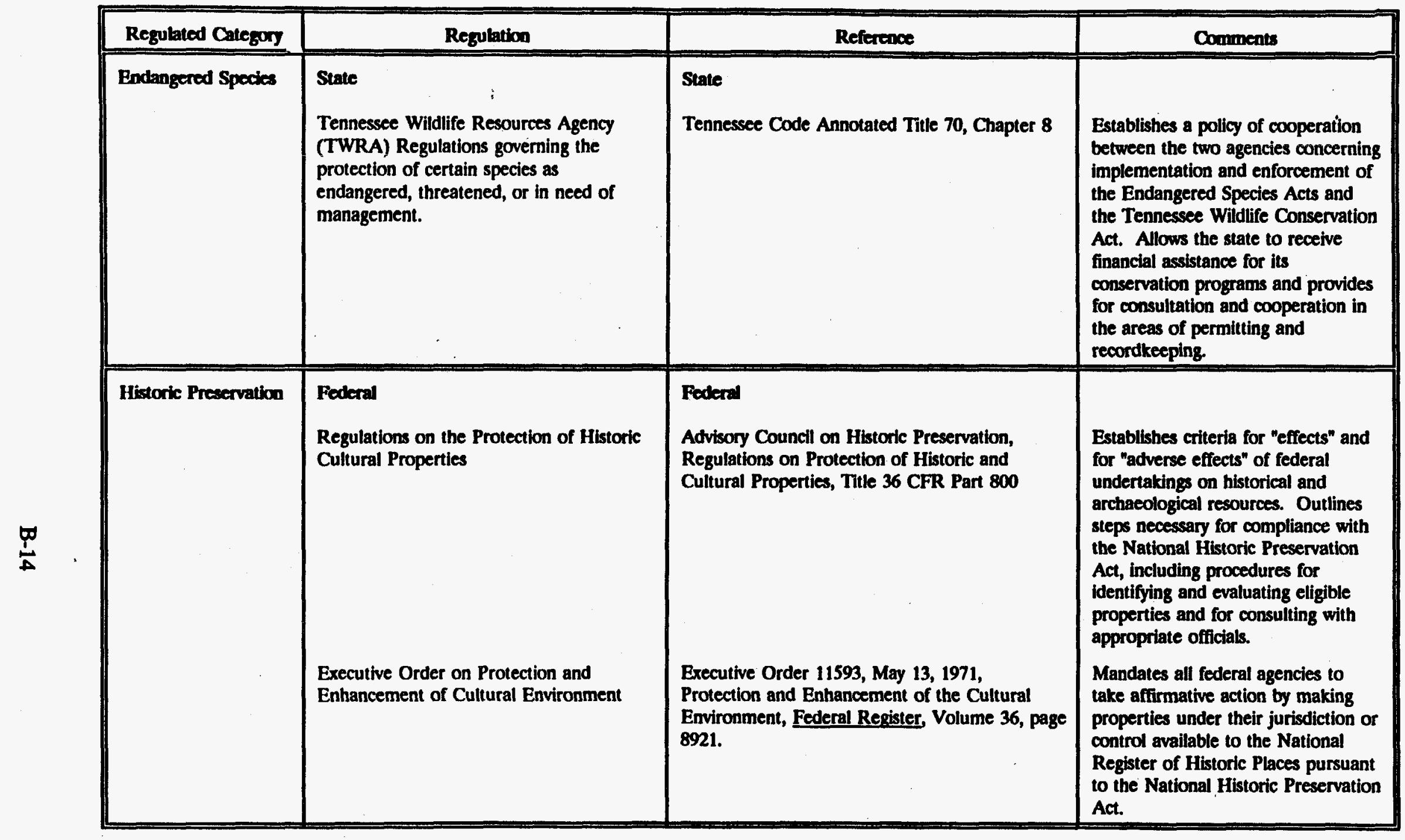




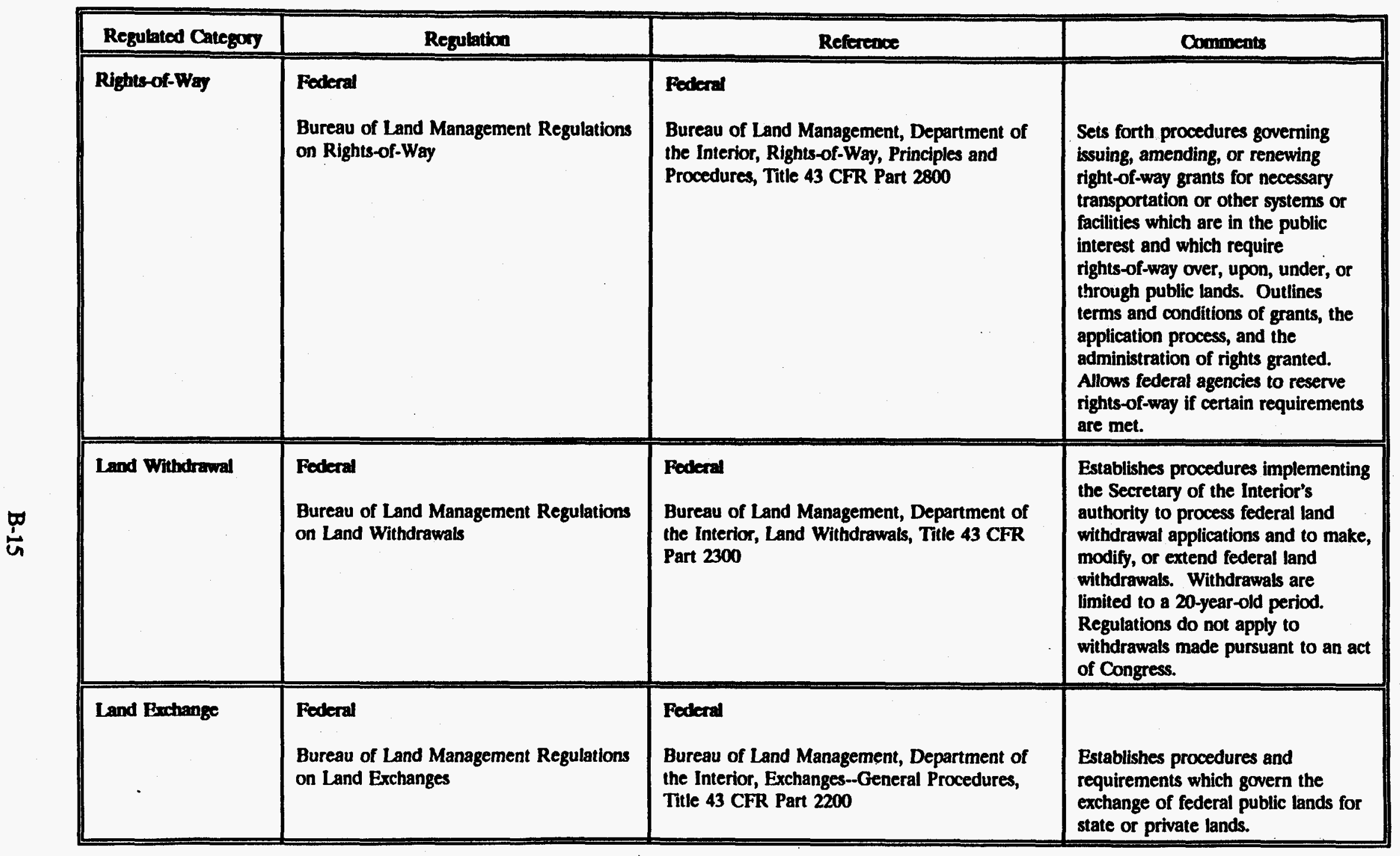




\begin{tabular}{|c|c|c|c|}
\hline Regulated Category & Regulation & Refierence & Comments \\
\hline NEPA Compliance & $\begin{array}{l}\text { Foderal } \\
\text { Council on Environmental Quality } \\
\text { Regulations in Implementing National } \\
\text { Environmental Policy. Act Procedures } \\
\text { Department of Energy Implementing } \\
\text { Procedures and Guidelines for NEPA }\end{array}$ & $\begin{array}{l}\text { Foderal } \\
\text { Council on Environmental Quality, National } \\
\text { Environmental Policy Act-Regulations, } \\
\text { Implementation of Procedural Provisions, } \\
\text { Tite } 40 \text { CFR Parts } 1500 \text { through } 1508 \\
\text { Department of Energy, National Environmental } \\
\text { Policy Act: Implementing Procedures and } \\
\text { Guidelines, Title } 10 \text { CFR Part } 1021\end{array}$ & $\begin{array}{l}\text { Establishes provisions applicable to } \\
\text { and binding on all federal agencies } \\
\text { for implementing the procedural } \\
\text { requirements of the national } \\
\text { Environmental Policy Act. Includes } \\
\text { procedures for planning (Part 1501), } \\
\text { preparing environmental impact } \\
\text { statements (Part 1502), } \\
\text { decision-making (Part 1505), and } \\
\text { compliance (Part 1507). } \\
\text { Establishes DOE guidelines for } \\
\text { implementing the procedural } \\
\text { provisions of NEPA pursuant to the } \\
\text { Councll on Environmental Quality } \\
\text { (CEQ) regulations. }\end{array}$ \\
\hline
\end{tabular}




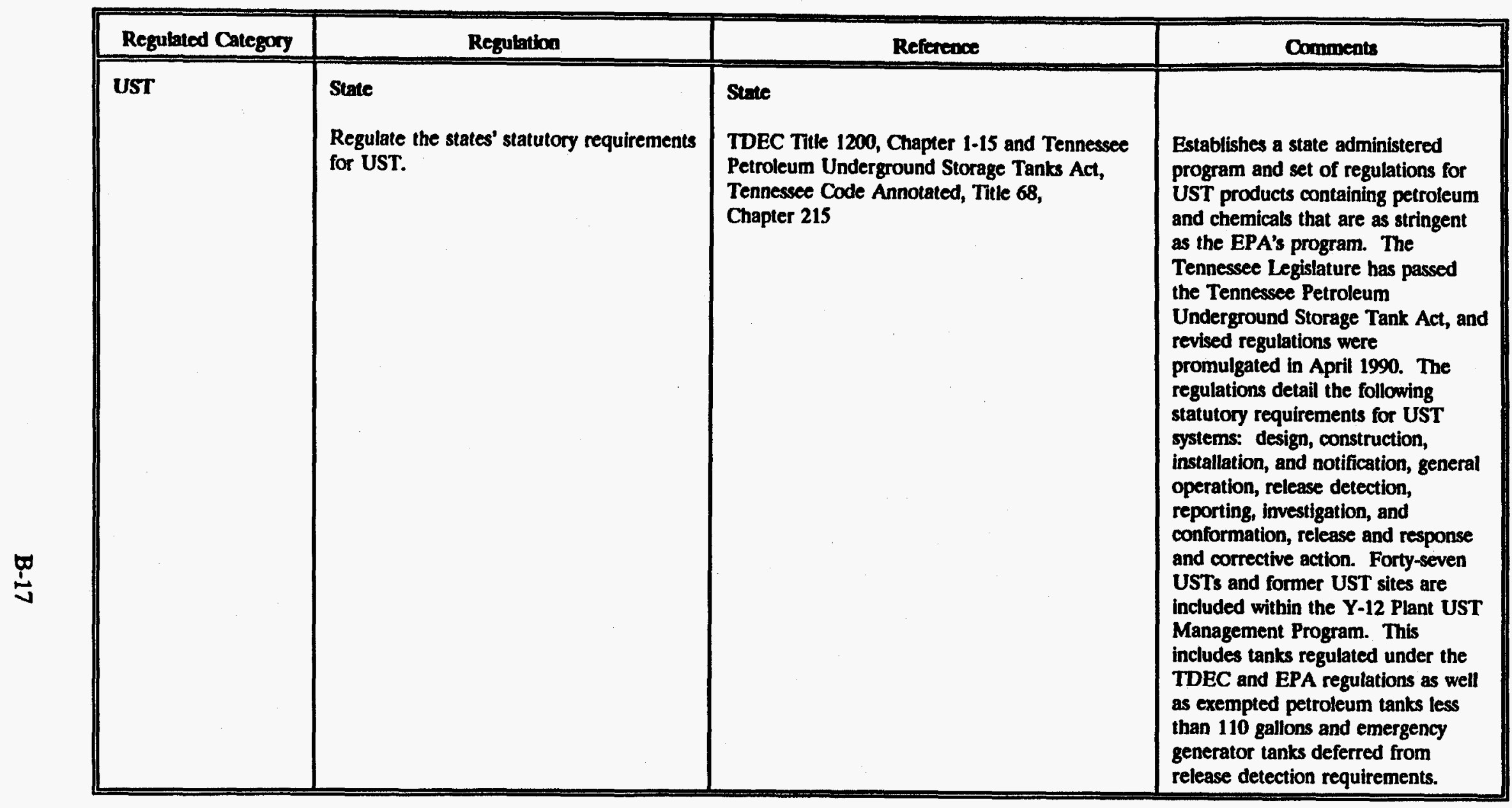


Appendix C

ORIG 5400.1C, General Environmental Protection Program 
ORIG $5400.1 \mathrm{C}$

$1-31-94$

\section{SUBJECT: GENERAL ENVIRONMENTAL PROTECTION PROGRAM}

1. PURPOSE. This Oak Ridge Implementation Guiuance (ORIG) correlates to DOE 5400.1, GENERAL ENVIRONMENTAL PROTECTION PROGRAM, of 11-9-88, by assigning responsibility and accountability and providing administrative and/or contractual guidance to Oak Ridge Operations Office (ORO) and its contractors. Nothing in this issuance changes any requirements contained in any DOE Order.

2. CANCELIATION. This issuance cancels and replaces ORIG Notice 5400.1B, GENERAL ENVIRONMENTAL PROTECTION PROGRAM, Of 10-27-93.

3. APPLICABILITY. The provisions of this ORIG apply to ORO Principal Staff and contractors and subcontractors who perform work for the Department as provided by law and/or contract and as implemented by the contracting officer.

4. REFERENCES.

a. ORIG N 5400.2B, ENVIRONMENTAL COMPLIANCE ISSUE COORDINATION, Of 10-27-93.

b. ORIG 5482.1D, ENVIRONMENT, SAFETY, HEALTH, AND QUALITY ASSURANCE APPRAISAL PROGRAM, Of 1-26-94.

c. ORIG N 5700.6C, QUALITY ASSURANCE, of 9-17-93.

5. DEEINITIONS. None.

6. RESPONSIBILITIES - FEDERAI.

a. Manager:

(1) Transmits requests for exemptions from standards in Federal, state, and local laws and regulations to the cognizant authority, and notifies the Assistant Secretary for Environment, Safety, and Health (EH-1), the Office of General Counsel (GC-1), and the Cognizant Secretarial officer (CSO) of the disposition of the request.

(2) Transmits requests for temporary and permanent exemptions from internal DOE environmental standards to EH-1, with copies to the cso.

(3) Approves/disapproves requests for field-level exemptions from internal DOE environmental standards to be enforced during the period of time in which a temporary or permanent exemption request is being processed by DOE Headquarters (HO).

b. Director, Environmental Protection Division (ENVPD) : 
(1) Conducts, when requested by the Manager or the CORs, selfassessment activities of contractor environmental programs. Sel.--assessment activities are directed by the CORs and include appraisals, as described in ORIG 5482.1D, surveillances, and audits.

(2) Issues and revises, as necessary, the ORO Environmental Protection Policy Statement included as Attachment 1 of this ORIG.

(3) Analyzes, concurs with, and coordinates with DOE-HQ, as necessary, the plans and reports submitted by contractors in accordance with subparagraph $7 \mathrm{~g}$ of this ORIG that address multiple sites, programs, or organizations. These analyses and concurrences ensure that the subject documents are technically correct, adequately address current and upcoming environmental 1ssues, meet DOE requirements, and cover the breadth and scope of the ongoing environmental protection program.

(4) Maintains a qualified and trained staff, which provides technical and regulatory support to CORs, to accomplish environmental protection program objectives, and to assist in communications and negotiations with regulatory agencies, DOE-HQ, and the public.

(5) Maintains liaison with appropriate Federal, regional, state, and local environmental officials so as to facilitate effective environmental management by:

(a) Attending meetings involving Federal, regional, state, and local environmental officials le.g.. monthly Tennessee Oversight Agreement meetings with the State of Tennessee, quarterly Environmental Restoration/waste Management meetings, and U.S. Environmental Protection Agency Region IV annual Federal Agency forum).

(b) Providing a point of contact for the City of Oak Ridge Environmental Quality Advisory Board (EQAB) and coordinating with CORs to provide requested information to EQAB.

(6) Conducts independent assessments of contractor environmental protection programs, as described in ORIG N 5700.6C.

(7) Coordinates with the Assistant to the Manager for Public Information the public release and press conference activities for the annual site environmental report for the Oak Ridge Reservation.

(8) Serves as the point of contact for ORO on environmental monitoring issues and coordinates reports for the Oak Ridge Reservation. 
(9) Maintains current awareness of changes to DOE policy and environmental regulations, and communicates such changes and relevant guidance on implementation to line management and contractors.

(10) Performs coordination activities on environmental issues between ORO and DOE-HQ, as described in ORIG N 5400.2B.

(11) Coordinates the ORO review and compilation of comments on supplemental guidance issued by the DOE-HQ Office of Environmental Compliance to implement DOE 5400.1, as requested.

(12) Provides technical advice to the Manager and CORs, as requested, and concurs/nonconcurs with requests for exemptions from standards in Federal, state, and local laws and regulations; requests for temporary and permanent exemptions from internal DOE environmental standards; and requests for field-level exemptions from internal DOE environmental standards to be enforced during the period of time in which a temporary or permanent exemption request is being processed by DOE-HQ.

c. Director, Planning and Budget Division:

(1) Establishes OMB Circular A-106 guidance for ORO.

(2) Coordinates submittal of a consolidated ORO A-106 report to DOE-HQ.

d. Office of Chief Counsel:

(1) Advises the ORO organizations on interpretation of proposed and existing environmental laws and regulations; participates in the negotiation of and/or reviews compliance agreements with a state agency or Environmental Protection Agency; and reviews other environmental documents and communications with regulatory agencies, DOE-HQ, contractors, and the public.

(2) Coordinates ORO environmental litigation activities with the GC-I and the U.S. Department of Justice. Assists in the development of ORO responses to Notices of Violation (NOVs), Notices of Defleiency (NODs), and other administrative complaints. Represents ORO in hearings and administrative proceedings (e.g., hearings on NOVs and hearings on appeals of permit conditions).

e. Assistant to the Manager for Public Information:

(1) Develops community public information and education programs concerning ORO environmental protection programs, consistent with the requirements of environmental regulations and national security interests. 
(2) Arranges a pjess conference for the public release of the Oa:: Ridge Reservation Annual Environmental Report.

$\therefore$ Contracting Officers' Representatives (CORs).

(1) Perform those tasks identified in subparagraphs $9 f(2)-(4)$, (7), (9), (10), and (12) of DOE 5400.1.

(2) As appropriate, provide those reports submitted by contractors in accordance with subparagraph $7 \mathrm{~g}$ of this ORIG that address multiple sites, programs, or organizations to the ENVPD for analysis and concurrence. In addition, provide other information, as requested by ENVPD, to somplete reports and other submittals to regulators or DOE-HO.

(3) Keep the ENVPD updated on all significant site or program environmental issues occurring, consistent with the requirements of ORIG N 5400.2B.

(4) Coordinate with the Assistant to the Manager for Public Information on those environmental protection programs that are likely to become matters for public forum and discussion, or matters on which public information and education programs are appropriate.

(5) Originate requests for exemptions or approve/disapprove contractor requests for exemptions from standards in Federal, state, and local laws and regulations at contractor-operated facilities.

(6) Assure the requirements of ORIG $N 5400.2 B$ are met when negotiating the terms and conditions of permits, settlements, consent orders, consent decrees, or other legal or administrative documents.

(7) Approve/disapprove contractor requests for exemptions from internal DOE environmental standards.

(8) Develop requests for field-level exemptions from internal DOE environmental standards to be enforced during the period of time in which a temporary or permanent exemption request is being processed by DOE-HQ.

(9) Coordinate the submittal of exemption requests within ORO and DOE-HQ, and to appropriate Federal, state, and local regulatory agencies.

(10) Establish procedures, as needed, to implement the requirements of DOE 5400.1 and this ORIG.

7. RESPONSIBIIITIES - CONTRACTORS.

a. Execute environmental protection programs that comply with the 
requirements of the General Environmental Protection Program as establ:.shed in DOE 5400.1, this ORIG, and any suppleme.1tal guidance issued by the EH-1 to implement DOE 5400.1 .

b. Take measures such as source readction, material substitution, recycling, and insofar as practicable, reduction of toxicity and waste volume to prevent generation of contaminants, wastes, and other residual materials requiring disposal.

c. Conduct and/or assist ORO in the conduct of community public information and education programs concerning ORO-wide or sitespecific environmental protection programs.

d. Originate requests for exemptions from standards in Federal, state, and local laws and regulations, and from internal DOE envirommental standards, and forward them to the cognizant COR for appropriate action.

e. Transmit the Radioactive Effluent and On-site Discharge Data Reports, as required by paragraph 5 of Chapter II of DOE 5400.1, with copies to the cognizant COR.

f. Establish procedures, as needed, to implement the requirements of DOE 5400.1 and this ORIG.

9. Prepare reports identified in Chapters II, III, and IV of DOE 5400.1, and forward them to the cognizant COR for appropriate action.

8. PROCEDURES. NONE.

9. RECORDS. None.

10. ATtackmints. Environmental Protection Policy statement, of 4-9-92.

Daniel H. Wilken

Assistant Manager

for Administration

\section{ATTACHMENT}

\section{ENVIRONMENTAL PROTECTION STATEMENT} DOE OAK RIDGE FIELD OFFICE

It is the policy and practice of the DOE Oak Ridge Field office (OR) to conduct its operations in a safe and environmentally sound manner, ensuring incorporation of all departmental and national environmental protection goals in the daily conduct of business. These goals are contained in federal statutes, executive orders, and DOE Orders. A listing of key federal Statutes and Executive Orders is provided in the attachment. OR and its contractors will make every effort to conduct operations in compliance with the letter and spirit of applicable environmental statutes, regulations, standards, and DOE Orders and to fulfill the requirements of the DOE Environmental Restoration and Waste 
Management Five-Year Plan, in full cooperation with all state and federal ragulatory organizations.

Even when not required by laws or regulations, appropriate measures will be undertaken to prevent the generation of contaminants, wastes, and other residual materials requiring disposal through source reduction, material substitution, and recycling. Also, the toxicity and volumes of waste will be reduced as much as practicable.

OR and its contractors share responsibility for sound environmental management, limiting the risks to the environment, and protecting public health. The help fulfill these responsibilities, a pollution prevention ethic will be maintained within the workplace through training, special campaigns, and incentive programs Also contractor award fees will reflect a strong emphasis on environment, safety, and health performance.

Joe La Grone Manager

Date: $[4-9-92]$

\author{
ATTACHMENT TO \\ ENVIRONMENTAL PROTECTION STATEMENT \\ DOE OAK RIDGE FIEID OFEICE
}

\title{
LEGISIATION.
}

- Title 42 U.S.C. Paragraph 2011, et seq., The Atomic Energy Act of 1954, as amended which authorizes the conduct of atomic energy activities.

- Title 42 U.S.C. Paragraph 7101, et seq.. The Department of Energy Organization Act, which establishes the statutory responsibility to ensure incorporation of national environmental protection goals in the formulation of energy programs, and advance the goal of restoring, protection, and enhancing environmental quality, and assuring public health and safety.

- Title 42 U.S.C. Paragraph 4321, et seq., The National Environmental Policy Act of 1969, as amended, which establishes broad national environmental policy.

- Title 42 U.S.C. Paragraph 7401, et seq., The Clean Air Act, as amended, which provides requirements to protect and enhance the quality of the Nation's air resources to promote the public health and welfare.

- Title 33 U.S.C. Paragraph 1252, et seq.. The Federal Water Pollution Control Act, as amended, which provides requirements to restore and main the chemical, physical, and biological integrity of the Nation's waters.

- Title 42 U.S.C. Paragraph 6901, et seq.. Solid Waste Disposal Act of 1965, as amended, which authorizes the U.S. Environmental Protection Agency (EPA) to regulate hazardous and solid waste. 
- Title 40 U.S.C. Paragraph 9601, et seq. The Comprehensive Environmental Response, Compensation, and Liability Act of 1980, as amended, which requires the identification, characterization, and cleanup of inactive hazardous waste sites by responsible parties. and imposes certain response and reporting requirements for operations from which hazardous substances have been released.

- Title 42 U.S.C. Paragraph 300f, et seq.. The Safe Drinking Water Act, as amended, which authorizes EPA to promulgate regulations under two specific programs: the first protects the Nation's public drinking water supplies; the second protects subsurface waters.

- Title 16 U.S.C. Paragraph 1451, et seq.. The Coastal Zone Management Act of 1972, as amended, which establishes and supports national coastal zone management policies.

- Title 16 U.S.C. Paragraph 1531, et seq., The Endangered Species Act of 1973, as amended, which establishes a program for the conservation of endangered species and their ecosystems.

- Title 42 U.S.C. Paragraph 662, et seg., The Fish and Wildlife Coordination Act, as amended, which authorizes the Secretary of the Interior to provide assistance to and cooperate with public and private organizations in the development and protection of the Nation's fish and wildilfe.

- Title 16 U.S.C. Paragraph 470, et seq.. The National Historic Preservation Act of 1966, as amended, which establishes the policy of the U.S. Government to protect and preserve historical structures, sites, and artifacts.

- Title 15 U.S.C. Paragraph 2601, et seq.. Toxic Substances Control Act, as amended, which provides requirements to safely regulate the manufacture, processing, distribution in comerce, use or disposal of chemical substances and mixtures which may present an unreasonable risk to either the public health or the environment.

- Title 42 U.S.C. Paragraph 1996, et seq.. The American Indian Religious Freedom Act, as amended, which establishes a policy of the U.S. government to protect and preserve for American Indians their inherent right of freedom of religion, including access to sites.

- Title 7 U.S.C. Paragraph 136, et seq., The Federal Insecticide, Fungicide, and Rodenticide Act, as amended, which authorizes EPA to promilgate regulations governing the use and disposal of pesticides.

- Title 42 U.S.C. Paragraph 4901, et seq., The Noise Control Act of 1972, as amended, which establishes a means for coordination of federal noise control research, setting noise emission standards, and providing information to the general public.

- Title 33 U.S.C. Paragraph 1401, et seq., The Marine Protection, Research, S Sanctuaries Act, as amended, which regulates the dumping of materials into ocean waters. 
Iitle 16 U.S.C. Paragraph 1271, et seq., The Wild \& Scenic Rivers Act, is amended, which establishes a national wild and scenic rivers system =o preserve and protect selected rivers of the Nation.

ritle 42 U.S.C. Paragraph 10101, et seq.. The Nuclear Waste Policy Act of 1982, as amended, which provides for the development of repositories for the disposal of high-level radioactive waste and spent fuel, and to establish a program of research, development, and demonstration regarding the disposal of high-level radioactive waste and spent nuclear fuel.

Title 42 U.S.C. Paragraph 2021, et seq., The Low-Level Radioactive Waste Policy Act, as amended, which establishes procedures for the implementation of compacts providing for the establishment and operation of regional disposal facilities for low-level radioactive waste.

Title 42 U.S.C. Paragraph 7901, et. seq., The Uranium Mill Tailings Radiation Control Act of 1978, as amended, which provides for a remedial action program at selected inactive uranium mill tailings sites.

Title 42 U.S.C. Paragraph 13101, et. seq., The Pollution Prevention Act of 1990, which establishes prevention or reduction of pollution at the source as a national policy and requires EPA to establish a source reduction program.

\section{ECUTIVE ORDERS.}

Executive Order 11991, "Protection and Enhancement of Environmental Quality," of May 7, 1970, including its amendment, Executive Order 11991 of May 24, 1977, which requires that the federal government shall provide leadership in protecting and enhancing the quality of the Nation's environment to sustain and enrich human life.

Executive Order 12088, "Federal Compliance with Pollution Control Standards," of October 13, 1978, which requires that all federal facilities and activities comply with applicable pollution control standards.

Executive Order 12580, "Superfund Implementation," of January 23, 1987, which delegates to various federal officials the responsibilities vested in the President for implementing the Comprehensive Environmental Response, Compensation, and Liability, Act of 1980 (CERCLA or Superfund) and the Superfund Amendments and Reauthorization Act of 1986 (SARA). [The order delegates most of these responsibilities to the Administrator of the Environmental Protection Agency (EPA), but several are delegated to the heads of federal agencies, including DOE.]

refice of Management and Budget (OMB) Circular No. A-106, "Reporting uirements in Connection with the Prevention, Control, and Abatement Environmental Pollution of Existing Federal Facilities, " of .ember 31, 1974 . 
Appendix D

Libraries and Public Reading Rooms

DOE Oak Ridge Operations Field Office

D-1 


\section{Appendix D}

Libraries and Public Reading Rooms

DOE Oak Ridge Operations Office

THE FOLLOWING IS A LIST OF ROUTINE DISTRIBUTION CENTERS TO WHICH ALL UNCONTROLLED DOCUMENTS OR REPORTS ARE SENT AND MADE AVAILABLE TO THE GENERAL PUBLIC:

\begin{abstract}
ALBUQUERQUE PUBLIC LIBRARY Information Services Department 501 Copper Avenue Northwest Albuquerque, New Mexico 87102 (505) 768-5140
\end{abstract}

\section{U.S. DEPARTMENT OF ENERGY-ID}

Public Reading Room

University Place 1776 Science Center Drive Idaho Falls, Idaho 83402 (208) 526-1144

\section{US. DEPARTMENT OF ENERGY-RL Hanford Science Center 825 Jadwin Avenue Richland, Washington 99352 (509) 376-8583}

\section{US. DEPARTMENT OF ENERGY-CH}

Public Reading Room

9800 Cass Avenue - Bldg 201

Argonne, Illinois 60439

(312) 972-2010

U.S. DEPARTMENT OF ENERGY-NV

Public Reading Room

2753 South Highland Street

Las Vegas, Nevada 89109

(702) 295-1274

U.S. DEPARTMENT OF ENERGY-OR

Public Reading Room

Federal Building

200 Administration Road

Oak Ridge, Tennessee 37830

(615) 576-1216
WIPP PUBLIC READNG ROOM

National Atomic Museum

U.S. Department of Energy

Albuquerque Operations Office

P.O. Box 5400

Albuquerque, New Mexico 87115

(505) 844-8443

US. DEPARTMENT OF ENERGY-OAR

Public Reading Room

1333 Broadway - 7th Floor

Oakland, California 94612

(415) $273-4428$

U.S. DEPARTMENT OF ENERGY-HO

Public Reading Room

Room 1E-190 Forrestal Bldg

1000 Independence Avenue, SW

Washington, DC 20585

(202) 586-6020

U.S. DEPARTMENT OF ENERGYSR

University of South Carolina-Aiken

Gregg-Graniteville Library

171 University Parkway

Aiken, South Carolina 29801

(803) 725-1408; ext. 3320

DOCUMENT CONTROL

Scientific \& Technical Information

Technical Information Center

P.O. Box 62

Oak Ridge, TN 37830 


\section{Appendix E}

\section{Y-12 Summary of Report Contents}

for the

Oak Ridge Reservation Annual Site Environmental Report 


\section{Appendix E}

Y-12 Summary of Report Contents for the Oak Ridge Reservation Annual Site Environmental Report

1. Site Operations and Overview

Background

Description of Site Locale

Climate

Description of Site, Facilities, and Operations

2. Environmental Compliance

Introduction

Compliance Activities

Environmental Permits

Notices of Violations and Penalties

Current Issues

3. Environmental Program Information

Environmental Monitoring Program for the Oak Ridge Reservation

Environmental Restoration

Other Environmental Programs

Waste Management

Pollution Prevention

Centers for Environmental Technology and Waste Management

Public Participation and Stakeholder Involvement

Environmental Research

4. Effluent Monitoring

Airborne Discharges

Liquid Discharges

5. Environmental Surveillance

Meteorological Monitoring

External Gamma Radiation Monitoring

Ambient Air Monitoring

Surface Water Monitoring

Soil

Sediment

Food

6. Dose

Radiation Dose

Terminology

Chemical Dose 


\section{Appendix E}

Y-12 Summary of Report Contents for the Oak Ridge Reservation Annual Site Environmental Report

7. Groundwater

Introduction

Groundwater Monitoring at the Y-12 Plant

Groundwater Monitoring at the Oak Ridge National Laboratory

Groundwater Monitoring at the K-25 Site

8. Quality Assurance

Introduction

Field Sampling Quality Assurance

Analytical Quality Assurance

Data Management, Verification, and Validation

9. Special Studies

Special Studies at the Y-12 Plant

Special Studies at Oak Ridge National Laboratory

Special Studies at the K-25 Site

Appendices 


\begin{abstract}
Appendix F
Y-12 Schedule for Preparation and Release of the Oak Ridge Reservation Environmental Report
\end{abstract}




\section{Appendix F \\ Y-12 Schedule for Preparation and Release of the ORR Environmental Report}

\begin{tabular}{|c|c|c|c|}
\hline & Action & Responsible Organization & Due Date \\
\hline 1. & $\begin{array}{l}\text { Conduct preliminary planning meetings } \\
\text { and obtain agreement with all } \\
\text { organizations regarding schedule. } \\
\text { Submit informational correspondence to } \\
\text { inform DOE ENVPD and Energy } \\
\text { Systems Management. }\end{array}$ & $\begin{array}{l}\text { Environmental Report } \\
\text { Coordinator }\end{array}$ & $01 / 09$ \\
\hline 2. & $\begin{array}{l}\text { Submit narratives and figures describing } \\
\text { monitoring systems and programs. Do } \\
\text { not include summary and conclusions } \\
\text { narrative at this time. Compile list of } \\
\text { sampling stations and environmental } \\
\text { permits. }\end{array}$ & $\begin{array}{l}\text { Site Environmental Report } \\
\text { Coordinator (SERC) }\end{array}$ & $01 / 19$ \\
\hline 3. & $\begin{array}{l}\text { Submit narratives for special studies } \\
\text { which have already been completed. }\end{array}$ & SERC & $01 / 19$ \\
\hline 4. & $\begin{array}{l}\text { Submit remaining special study } \\
\text { narratives. }\end{array}$ & SERC & $01 / 27$ \\
\hline 5. & Send dose calculation data to ORNL. & SERC & 02,02 \\
\hline 6. & $\begin{array}{l}\text { Submit all data input to environmental } \\
\text { report coordinator. Include summary } \\
\text { and conclusions narrative at this time. }\end{array}$ & SERC & 0223 \\
\hline 7. & $\begin{array}{l}\text { Complete dose calculations and send } \\
\text { results with narrative and conclusions to } \\
\text { the environmental report coordinator. }\end{array}$ & ORNL EMD & $02 / 23$ \\
\hline 8. & Issue draft for review. & $\begin{array}{l}\text { Environmental Report } \\
\text { Coordinator }\end{array}$ & $03 / 19$ \\
\hline 9. & $\begin{array}{l}\text { First draft for technical review; } \\
\text { comments returned to environmental } \\
\text { report coordinator. }\end{array}$ & SERC, EC, and ENVPD & $03 / 30$ \\
\hline 10. & $\begin{array}{l}\text { Submit DRAFT Environmental } \\
\text { Compliance Summary for review by } \\
\text { DOE-HQ. }\end{array}$ & $\begin{array}{l}\text { Environmental Report } \\
\text { Coordinator }\end{array}$ & $04 / 15$ \\
\hline 11. & Issue final draft report for review. & $\begin{array}{l}\text { Environmental Report } \\
\text { Coordinator }\end{array}$ & $04 / 23$ \\
\hline
\end{tabular}




\section{Appendix F}

Y-12 Schedule for Preparation and Release of the ORR Environmental Report (Cont.)

\begin{tabular}{||ll|l|c|}
\hline \multicolumn{2}{|c|}{ Action } & Responsible Organization & Due Date \\
\hline 12. & $\begin{array}{l}\text { Final draft for technical review; } \\
\text { comments returned to environmental } \\
\text { report coordinator. }\end{array}$ & SERC, EC, and ENVPD & $05 / 02$ \\
\hline 13. & $\begin{array}{l}\text { Publish final ORR Environmental } \\
\text { Report after concurrence of ENVPD } \\
\text { and DOE-HQ. }\end{array}$ & $\begin{array}{l}\text { Environmental Report } \\
\text { Coordinator }\end{array}$ & $05 / 25$ \\
\hline 14. & Issue final report. & $\begin{array}{l}\text { Environmental Report } \\
\text { Coordinator }\end{array}$ & $06 / 01$ \\
\hline 15. & Press Conference. & $\begin{array}{l}\text { Environmental Report } \\
\text { Coordinator and ENVPD }\end{array}$ & June \\
\hline
\end{tabular}


Appendix G

Environmental Monitoring Plan for the Oak Ridge Reservation, Table of Contents 


\section{Appendix G}

ENVIRONMENTAL MONITORING PLAN FOR THE

OAK RIDGE RESERVATION, TABLE OF CONTENTS ${ }^{2}$

1. Introduction

1.1 Purpose

1.2 Scope

1.3 General Considerations

1.4 Objectives

1.5 Overview

1.6 Regulatory Guide Performance Criteria, General Comments

2. Effluent Monitoring

2.1 Surface Water

2.2 Groundwater

2.3 Airborne

3. Meteorological Monitoring

4. Environmental Surveillance

4.1 Ambient Air

4.2 External Gamma Radiation

4.3 Groundwater

4.4 ORR-Surface Water/Sediments/Aquatic Biota

4.5 ORR-Vegetation/Soil

4.6 ORR-Terrestrial Environment

4.7 Regulatory Guide Performance Criteria

5. Laboratory

6. Dose Calculations

7. Data Management, Analysis, and Statistical Treatment

8. Reports

9. Quality Assurance Program

10. References

The Environmental Monitoring Plan is one plan which addresses both effluent monitoring and environmental surveillance activities for the K-25 Site, the Y-12 Plant, ORNL, the Oak Ridge Reservation, and off-site surveillance activities. 
Distribution:

T. R. Butz

J. P. Donnelly, DOE-ORO

J. G. Rogers

F. P. Gustavson

C. C. Hill

L. W. McMahon

W. G. McMillan, DOE-ORO

S. D. Morris, DOE-ORO

J. P. O'Heam, MK-Ferguson

J. E. Powell

L. M. Sparks, DOE-ORO

R. J. Spence/D. K. Hoag, DOE-ORO

C. L. Stair

S. W. Wiley

Y12 Records Services (1)/DOE-OSTI (2)

Y-12 HSEA Document Center

File-EMD-RC 